\title{
Global land-atmosphere exchange of methane and nitrous oxide: magnitude and spatiotemporal patterns
}

H. $\operatorname{Tian}^{1}$, G. Chen ${ }^{1,2}$, C. Lu ${ }^{1}$, X. Xu ${ }^{1,2}$, W. Ren ${ }^{1}$, K. Banger ${ }^{1}$, B. Zhang ${ }^{1}$, B. Tao ${ }^{1}$, S. Pan ${ }^{1}$, M. Liu ${ }^{1,3}$, and C. Zhang ${ }^{1,4}$

${ }^{1}$ International Center for Climate and Global Change Research, School of Forestry and Wildlife Sciences, Auburn University, Auburn, AL 36849, USA

${ }^{2}$ Environmental Sciences Division, Oak Ridge National Laboratory, Oak Ridge, TN 37831 , USA

${ }^{3}$ Department of Civil and Environmental Engineering, Washington State University, Pullman, WA 99164, USA

${ }^{4}$ Xinjiang Institute of Ecology and Geography, Chinese Academy of Sciences, Urumqi, 830011, China

Received: 31 October 2013 - Accepted: 28 November 2013 - Published: 17 December 2013 Correspondence to: H. Tian (tianhan @ auburn.edu)

Published by Copernicus Publications on behalf of the European Geosciences Union.
Global

land-atmosphere

exchange of methane

and nitrous oxide

H. Tian et al.

\section{Title Page}

\section{Abstract}

Introduction

Conclusions

Tables

References

Figures

14

$\rightarrow$ I

4

Back

Close

Full Screen / Esc

Printer-friendly Version

Interactive Discussion 


\section{Abstract}

Methane $\left(\mathrm{CH}_{4}\right)$ and nitrous oxide $\left(\mathrm{N}_{2} \mathrm{O}\right)$ are two most important greenhouse gases after carbon dioxide, but their regional and global budgets are far from certain, which is largely owing to uncertainties in scaling up field measurements as well as the poor

5 model representation of processes and factors governing $\mathrm{CH}_{4}$ and $\mathrm{N}_{2} \mathrm{O}$ exchange between the terrestrial biosphere and atmosphere. In this study, we applied a processbased, coupled biogeochemical model (DLEM - the Dynamic Land Ecosystem Model) to estimate the magnitudes, spatial and temporal patterns of $\mathrm{CH}_{4}$ and $\mathrm{N}_{2} \mathrm{O}$ fluxes as driven by multiple environmental changes including climate variability, rising atmospheric $\mathrm{CO}_{2}$, increasing nitrogen deposition, tropospheric ozone pollution, land use change and nitrogen fertilizer use. The estimated $\mathrm{CH}_{4}$ and $\mathrm{N}_{2} \mathrm{O}$ emissions from global land ecosystems were $169.43 \pm 32.92 \mathrm{Tg} \mathrm{Cyr}^{-1}$ and $12.52 \pm 1.52 \mathrm{Tg} \mathrm{Nyr}^{-1}$, respectively. Our simulations have indicated a significant $(P<0.01)$ increasing trend for $\mathrm{CH}_{4}$ $\left(0.75 \pm 0.08 \mathrm{TgC} \mathrm{yr}^{-1}\right)$ and $\mathrm{N}_{2} \mathrm{O}\left(0.14 \pm 0.02 \mathrm{TgNyr}^{-1}\right)$ during 1981-2010. $\mathrm{CH}_{4}$ and $15 \mathrm{~N}_{2} \mathrm{O}$ emissions increased significantly in most climatic zones and continents, especially in tropical region and Asia. The most rapid increase in $\mathrm{CH}_{4}$ emission was found in wetlands (including rice fields and natural wetlands) owing to increased rice field area and climate change; $\mathrm{N}_{2} \mathrm{O}$ emission increased substantially for all the biome types and the largest increase occurred in upland crops owing to increasing air temperature and nitrogen fertilizer use. Given large increase in $\mathrm{CH}_{4}$ and $\mathrm{N}_{2} \mathrm{O}$ emission at global scale, we suggest that these two gases together with $\mathrm{CO}_{2}$ have to be simultaneously considered when evaluating if a policy is effective or efficient to reduce global warming in the future.

\section{Introduction}

25 As two important greenhouse gases (GHG) contributing to climate warming, methane $\left(\mathrm{CH}_{4}\right)$ and nitrous oxide $\left(\mathrm{N}_{2} \mathrm{O}\right)$ are receiving more and more attention (Prather and

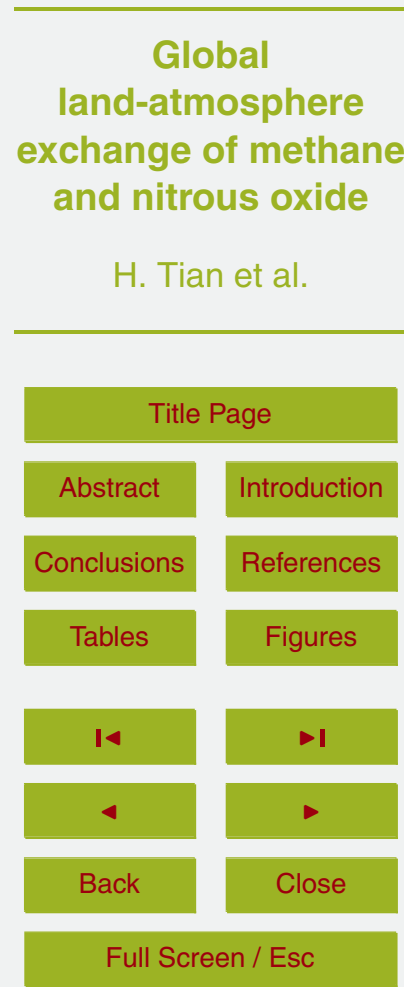


Hus, 2010; Montzka et al., 2011; Kirschke et al., 2013; Saikawa et al., 2013; Tian et al., 2012a). Recent analyses indicated that the atmospheric $\mathrm{CH}_{4}$ has increased by more than $100 \%$ since 1800 (Forster et al., 2007). Methane has a relative global warming potential 25 times that of $\mathrm{CO}_{2}$ at a $100 \mathrm{yr}$ time horizon, and contributes approxi-

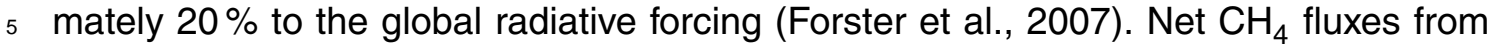
terrestrial ecosystems are primarily determined by two distinct microbial processes: methanogenesis (production) and methanotrophy (consumption) (Walter and Heimann 2000; Bloom et al., 2010). Methanogenesis occurs under anaerobic conditions, while methanotrophy occurs in aerobic or anaerobic condition. Many factors, such as water 10 table depth, substrate quality and quantity, soil $\mathrm{pH}$, soil moisture, presence of permafrost, oxygen concentration, and ratio of methanogenic to methanotrophic bacteria, directly influence $\mathrm{CH}_{4}$ production and consumption (Tian et al., 2010; $\mathrm{Xu}$ et al., 2010; Banger et al., 2012; Dijkstra et al., 2012). The dominant sources of $\mathrm{CH}_{4}$ are natural wetlands, anthropogenic activities, and biomass burning (Dlugokencky et al., 2009; Ito and Inatomi et al., 2012), while the major $\mathrm{CH}_{4}$ sink is the upland soils. Recent $\mathrm{CH}_{4}$ budget estimation showed a global source of 548-678 $\mathrm{Tg} \mathrm{CH}_{4} \mathrm{yr}^{-1}$ during 2000-2009, nearly 50-60\% from anthropogenic origin (Kirschke et al., 2013).

Atmospheric $\mathrm{N}_{2} \mathrm{O}$ has increased by $18 \%$ compared to the pre-industrial level, with a linear increasing rate of $0.26 \%$ per year during the recent few decades (Forster 20 et al., 2007). Nitrous oxide has a relative global warming potential 298 times that of $\mathrm{CO}_{2}$ at a $100 \mathrm{yr}$ time horizon, and contributes approximately $7 \%$ to the radiative forcing (Forster et al., 2007). Therefore, although its concentration is much less than that of $\mathrm{CO}_{2}$ and $\mathrm{CH}_{4}$ in the atmosphere, it is drawing more attention in recent years. The observed increase in atmospheric $\mathrm{N}_{2} \mathrm{O}$ concentration was primarily attributed to reactive nitrogen inputs from synthetic nitrogen fertilizer and animal manure applications, cropland expansion, and processes associated with fossil-fuel combustion and biomass burning. The production and consumption of $\mathrm{N}_{2} \mathrm{O}$ in soils involves both biotic and abiotic processes. Many microbial groups contribute to the production and consumption

BGD

10, 19811-19865, 2013

Global

land-atmosphere

exchange of methane and nitrous oxide

H. Tian et al.

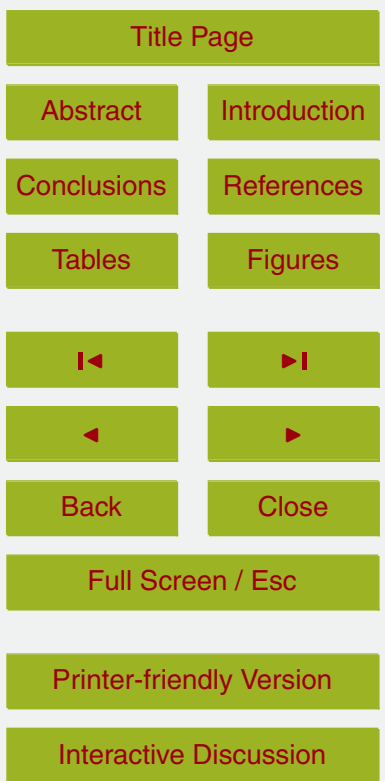


of soil $\mathrm{N}_{2} \mathrm{O}$, but biological nitrification and denitrification are the dominant processes (Ussiri and Lal, 2012).

A number of studies using different modeling and statistical approaches were conducted to estimate regional or global $\mathrm{CH}_{4}$ (e.g., Bousquet et al., 2006; Potter et al., 5 1996; Bloom et al., 2010; Tian et al., 2010; Xu et al., 2012; Zhuang et al., 2004; Schulze et al., 2009; Ito and Inatomi et al., 2012; Meng et al., 2012; Kirschke et al., 2013) and $\mathrm{N}_{2} \mathrm{O}$ fluxes (e.g., Xu et al., 2008; Liu, 1996; Hirsch et al., 2006; Davidson 2009; US EPA 2010; Bouwman et al., 2002; Zhuang et al., 2012). However, the estimates are far from certain due to the complexity of the terrestrial ecosystems and the shortage of field and laboratory measurements to validate the modeled processes controlling gas emissions (Ito and Inatomi et al., 2012; Tian et al., 2012a; Melton et al., 2013). To simulate largescale $\mathrm{CH}_{4}$ and $\mathrm{N}_{2} \mathrm{O}$ fluxes, two approaches are generally used during past decades: bottom-up (e.g., inventory and process-based modeling, Cao et al., 1995; Walter et al., 2001; Zhuang et al., 2004; Xu et al., 2008; Tian et al., 2010) and top-down (e.g., atmospheric inversion, Frankenberg et al., 2005; Bergamaschi et al., 2007, 2009; Kort et al., 2008; Bousquet et al., 2011; Spahni et al., 2011). Process-based modeling, as one of the bottom-up approaches, can simulate the spatial heterogeneity of ecosystem properties at relatively high resolution and identify the underlying mechanisms that control the magnitudes and variations of GHG fluxes (Spahni et al., 2011; Tian et al., 2010; Xu et al., 2010; Bousquet et al., 2011).

Many global change factors could affect the production and consumption of $\mathrm{CH}_{4}$ and $\mathrm{N}_{2} \mathrm{O}$ (Hutchin et al., 1995; Conrad, 1996; Huang et al., 2010; Toet et al., 2011). For instance, global warming was reported to increase both $\mathrm{CH}_{4}$ and $\mathrm{N}_{2} \mathrm{O}$ emissions (Dijkstra et al., 2012); elevated atmospheric $\mathrm{CO}_{2}$ increased $\mathrm{CH}_{4}$ emission (Dacey et al., 1994; Dijkstra et al., 2012), while decrease or increase $\mathrm{N}_{2} \mathrm{O}$ emission (Ineson et al., 1998; Kettunen et al., 2005); ozone $\left(\mathrm{O}_{3}\right)$ pollution reduced $\mathrm{CH}_{4}$ emission (Toet et al., 2011), while stimulated or reduced $\mathrm{N}_{2} \mathrm{O}$ emission (Kanerva et al., 2008); nitrogen fertilization could dramatically decrease $\mathrm{CH}_{4}$ consumption in grassland and forest (Mosier et al., 1991; Steudler et al., 1989), while increase $\mathrm{N}_{2} \mathrm{O}$ emissions (Del Grosso et al., 2006;

Global

land-atmosphere

exchange of methane and nitrous oxide

H. Tian et al.

Title Page

Abstract

Conclusions

Tables

Figures

14

4

Back $\rightarrow$ I

$\checkmark$

Close

Printer-friendly Version

Interactive Discussion

\section{Full Screen / Esc}


Mosier et al., 1998). Meanwhile, interactions among multiple factors also played an important role. For example, nitrogen deposition and elevated atmospheric $\mathrm{CO}_{2}$ were reported to interactively reduce $\mathrm{CH}_{4}$ emission from wetland (Pancotto et al., 2010); and another study concluded that temperature and elevated atmospheric $\mathrm{CO}_{2}$ might interactively change seasonal variation of $\mathrm{CH}_{4}$ emission (Blankinship et al., 2010). Previous studies addressed the impacts of only one or a subset of environmental factors on either $\mathrm{CH}_{4}$ or $\mathrm{N}_{2} \mathrm{O}$ fluxes; however, few of them were conducted to fully estimate the effects of multiple environmental changes (such as climate, land use, land management practices, atmospheric $\mathrm{CO}_{2}$, nitrogen deposition and tropospheric $\mathrm{O}_{3}$, etc.) on both gases. In addition, given the tight linkage between these two gases in both terrestrial origin (Raghoebarsing et al., 2006; Kort et al., 2008; Ettwig et al., 2010; Song et al., 2009; Dijkstra et al., 2012) and atmospheric chemistry (Prather and Hus, 2010), it is important to simultaneously estimate the $\mathrm{CH}_{4}$ and $\mathrm{N}_{2} \mathrm{O}$ fluxes at continental or global scale. In this study, we used a process-based model (the Dynamic Land Ecosystem

Model, DLEM; Tian et al., 2010) to estimate $\mathrm{CH}_{4}$ and $\mathrm{N}_{2} \mathrm{O}$ fluxes driven by multiple environmental changes in climate, atmospheric $\mathrm{CO}_{2}$, tropospheric $\mathrm{O}_{3}$ concentration, nitrogen deposition, land use and nitrogen fertilizer use. The DLEM model has been applied to quantify and attribute the responses of non- $\mathrm{CO}_{2}$ GHG fluxes to multiple environmental factors in China, North America and globe (Tian et al., 2010, 2011a, 2012a;
Xu et al., 2010, 2012a; Melton et al., 2013; Wania et al., 2013). Built upon our previous work, the specific objectives in this study were to: (1) estimate the magnitude of $\mathrm{CH}_{4}$ and $\mathrm{N}_{2} \mathrm{O}$ fluxes from terrestrial biosphere and (2) explore the spatial and temporal variations in terrestrial $\mathrm{CH}_{4}$ and $\mathrm{N}_{2} \mathrm{O}$ fluxes as influenced by multiple environmental factors on regional and global scales.
BGD

10, 19811-19865, 2013

Global

land-atmosphere

exchange of methane and nitrous oxide

H. Tian et al.

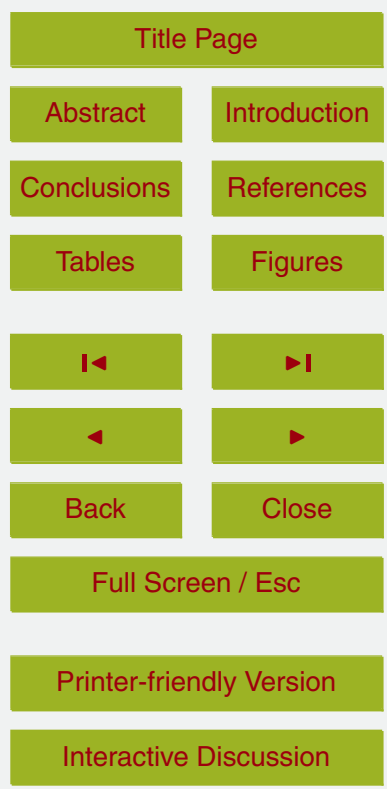




\section{Methodology}

\subsection{Data description}

In this study, we developed a series of spatiotemporal data sets to represent environmental changes at a spatial resolution of $0.5^{\circ} \times 0.5^{\circ}$ during 1901-2010. These data 5 include daily $\mathrm{O}_{3}$ AOT40 index (an index of the accumulated hourly ozone concentrations above a threshold of $40 \mathrm{ppb}$ ), annual nitrogen deposition rate, daily climate conditions (minimum, average and maximum temperature, precipitation, and solar radiation), annual land use and land management practices (including nitrogen fertilizer use and irrigation). The climate data was downloaded from CRUNCEP website. $\mathrm{O}_{3}$ AOT40 data 10 were derived from the monthly AOT40 data developed by Felzer et al. (2005). EDGARHYDE 1.3 nitrogen emission data (Van Aardenne et al., 2001) were used to interpolate the three-time period nitrogen deposition data $(1860,1993,2050$; Dentener, 2006) to generate annual nitrogen deposition data set during 1900-2010 (Wei et al., 2013). Land use data (Cropland and urban area distribution) were from History Database of the Global Environment (HYDE 3.0) (Klein and van Drecht, 2006). Nitrogen fertilizer use rate for China and the United States were developed from county-level census data (Tian et al., 2010, 2011b), while information in other regions were based on Food and Agriculture Organization (FAO) country-level statistical data (www.fao.org). Soil property data, including soil texture, $\mathrm{pH}$, and bulk density, were from Global Soil Data Task (www.daac.ornl.gov). The annual atmospheric $\mathrm{CO}_{2}$ concentration data before 1959 were from the Vegetation/Ecosystem Modeling and Analysis Project (VEMAP), and the data thereafter were from the National Oceanic and Atmospheric Administration (NOAA) (www.esrl.noaa.gov). The potential vegetation (i.e., natural vegetation) map was developed from different data sources, including global land-cover data derived
BGD

10, 19811-19865, 2013

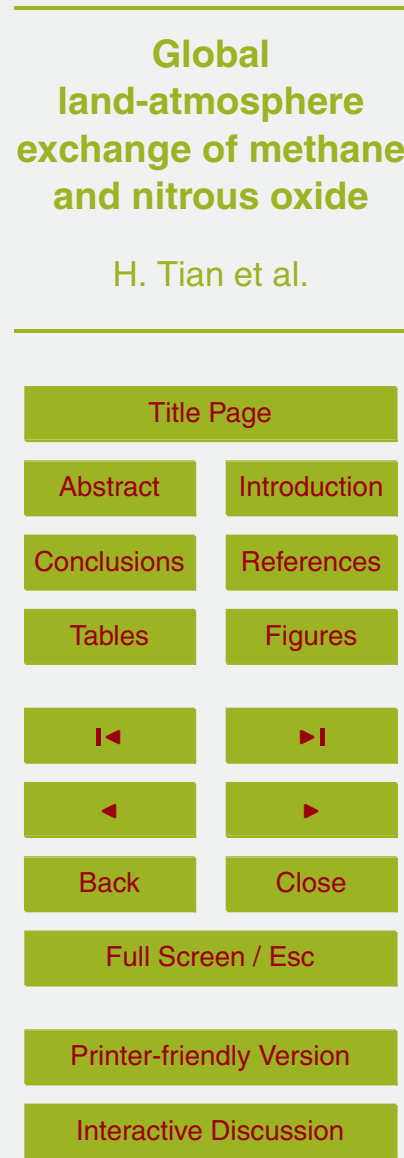
(www.usgs.gov), and global database of lakes, reservoirs, and wetland (Lehner and Döll, 2004). The contemporary global vegetation map in 2000 was shown in Fig. 1. All the datasets were transformed and re-projected to the same projection system. Due 19816
Interactive Discussion 
to the lack of data after 2005, the land use and land cover pattern, $\mathrm{O}_{3}$ AOT40, and nitrogen fertilizer use rate after 2005 were assumed the same as the level of 2005.

\subsection{Model description}

The DLEM model is designed to estimate carbon, nitrogen, and water fluxes and pool

5 sizes in terrestrial ecosystems by coupling major physiological, biogeochemical and hydrological processes, and vegetation dynamics with spatial coverage ranging from site to region and globe, and time step from daily to monthly and yearly (Tian et al., 2010, 2011a, b, 2012a, b). One of important DLEM's features is that it can simultaneously estimate the responses of land-atmosphere exchange of $\mathrm{CO}_{2}, \mathrm{CH}_{4}$ and $\mathrm{N}_{2} \mathrm{O}$ to multiple environmental changes in climate, atmospheric $\mathrm{CO}_{2}$ concentration, tropospheric $\mathrm{O}_{3}$ pollution, nitrogen deposition, land use and land management practices. Each plant functional type defined in DLEM (i.e., types shown in Fig. 1) was calibrated against various field observations collected from the Chinese Ecological Research Network (CERN), US Long-Term Ecological Research (LTER) network, AmeriFlux network, and other independent research sites. Here we briefly described the $\mathrm{CH}_{4}$ and $\mathrm{N}_{2} \mathrm{O}$ module in the DLEM. The more detailed information could be referred to Tian et al. (2010, 2011a, b, 2012b) and Xu et al. (2010, 2012).

In DLEM, $\mathrm{CH}_{4}$ production, consumption, and transport processes are considered to estimate land-atmosphere gas exchange. Dissolved organic carbon (DOC) is the only $\mathrm{CH}_{4}$ production substrate considered in DLEM. The DOC comes from gross primary productivity (GPP) allocation, and decomposition byproducts from soil organic matter and litterfall, which indirectly controlled by environmental factors including soil $\mathrm{pH}$, temperature and soil moisture content. $\mathrm{CH}_{4}$ oxidation is determined by $\mathrm{CH}_{4}$ concentrations in the air or pore space of soil, as well as soil moisture, $\mathrm{pH}$, and temperature. We diffusion, and plant-mediated transport) (Tian et al., 2010). It is assumed that methanerelated biogeochemical processes only occur in the top $50 \mathrm{~cm}$ of soil profile. Overall, the net $\mathrm{CH}_{4}$ exchange between the atmosphere and soil is calculated by the following

BGD

10, 19811-19865, 2013

Global

land-atmosphere

exchange of methane and nitrous oxide

H. Tian et al.

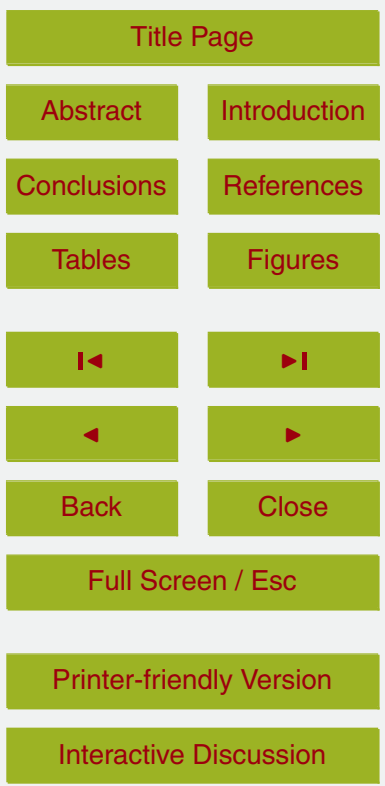


equation:

$F_{\mathrm{CH}_{4}}=F_{\mathrm{P}}+F_{\mathrm{D}}+F_{\mathrm{E}}-F_{\text {air, oxid }}-F_{\text {trans, oxid }}-F_{\text {soil, oxid }}$

where $F_{\mathrm{CH}_{4}}$ is the flux of $\mathrm{CH}_{4}$ between soil and the atmosphere $\left(\mathrm{g} \mathrm{Cm}^{-2}\right.$ day $\left.^{-1}\right) ; F_{\mathrm{P}}$ is plant-mediated transport from soil pore water to the atmosphere $\left(\mathrm{g} \mathrm{Cm}^{-2}\right.$ day $\left.^{-1}\right) ; F_{\mathrm{D}}$ 5 is the diffusive flux of $\mathrm{CH}_{4}$ from water surface to the atmosphere $\left(\mathrm{g} \mathrm{C} \mathrm{m}^{-2}\right.$ day $\left.{ }^{-1}\right) ; F_{\mathrm{E}}$ is the ebullitive $\mathrm{CH}_{4}$ emission to the atmosphere; $F_{\text {air, oxid }}$ is atmospheric $\mathrm{CH}_{4}$ oxidation rate $\left(\mathrm{g} \mathrm{Cm}^{-2}\right.$ day $\left.^{-1}\right)$; $F_{\text {trans, oxid }}$ is the $\mathrm{CH}_{4}$ oxidation during plant-mediated transport $\left(\mathrm{gCm}^{-2}\right.$ day $\left.^{-1}\right) ; F_{\text {soil, oxid }}$ is the $\mathrm{CH}_{4}$ oxidation rate in soil pore water.

Terrestrial nitrogen cycling processes considered in the DLEM model include nitro10 gen input from the atmospheric deposition, agricultural fertilizer use, and biological fixation, plant nitrogen uptake, nitrogen transformation (e.g., mineralization and immobilization, nitrification and denitrification, adsorption/desorption), and nitrogen loss (e.g., nitrous gas emissions, nitrogen leaching, and other nitrogen loss pathways through fire, grazing, or other disturbances). The estimation of $\mathrm{N}_{2} \mathrm{O}$ emissions (primarily from nitrification and denitrification) are closely interlinked with model representation of above processes.

In DLEM, all the products of nitrification and denitrification that leave the system are nitrogen-containing gases. We used the empirical equation reported by Davidson et al. (Davidson et al., 2000) to separate $\mathrm{N}_{2} \mathrm{O}$ from other gases (mainly $\mathrm{NO}$ and $\mathrm{N}_{2}$ ).

20 The equations for calculating nitrification, denitrification and $\mathrm{N}_{2} \mathrm{O}$ fluxes are:

$F_{\mathrm{N}_{2} \mathrm{O}}=\left(0.001 \times N_{\text {nit }}+N_{\text {denit }}\right) \times \frac{10^{\left(\frac{\mathrm{wwc}}{\emptyset} \times \times 0.026-1.66\right)}}{\left(1+10^{\left(\frac{\mathrm{wwc}}{\emptyset} \times \times 0.026-1.66\right)}\right)}$

where $F_{\mathrm{N}_{2} \mathrm{O}}$ is the $\mathrm{N}_{2} \mathrm{O}$ flux from soil to the atmosphere $\left(\mathrm{g} \mathrm{Nm}^{-3}\right.$ day $\left.^{-1}\right)$, which can be converted to the unit of $\mathrm{g} \mathrm{N} \mathrm{m}^{-2}$ day $^{-1}$ by multiplying the soil depth (default: $0.5 \mathrm{~m}$ ); 19818

Global

land-atmosphere

exchange of methane

and nitrous oxide

H. Tian et al.

Title Page

Abstract

Introduction

Conclusions

Tables

References

Figures

14

4

Back

Full Screen / Esc

Printer-friendly Version

Interactive Discussion
$>$ I

$>$

Close
Full Screen/Esc

(ive Discussion

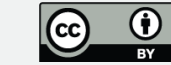


$N_{\text {nit }}$ and $N_{\text {denit }}$ are the nitrification and denitrification rates $\left(\mathrm{gNm}^{-3}\right.$ day $\left.^{-1}\right)$, respectively; 0.001 is the proportion of nitrification product released as gaseous nitrogen (Lin et al., 2000); $\varnothing$ is the soil porosity.

\subsection{Model implementation and experimental design}

5 The implementation of DLEM simulation includes three steps: (1) equilibrium run, (2) spin-up run, and (3) transient run. In this study, we first used land use and land cover map in 1900, long-term mean climate during 1901-1930, the concentration levels of nitrogen deposition, $\mathrm{O}_{3}$ pollution, atmospheric $\mathrm{CO}_{2}$ in 1900 to run the model to an equilibrium state (i.e., the inter-annual variations during 20 continuous years are less than $10 \quad 0.1 \mathrm{~g} \mathrm{C} \mathrm{m}^{-2}, 0.1 \mathrm{~g} \mathrm{Nm}^{-2}$ and $0.1 \mathrm{~mm}$ for carbon, nitrogen and water pools, respectively). After model reached equilibrium state, a spin-up run was implemented for $900 \mathrm{yr}$ using de-trended climate data during 1901-1930 (i.e., 30 spins with $30 \mathrm{yr}$ data each time). Finally, the model was run in transient mode with daily or annual environmental data from 1901 to 2010 to simulate $\mathrm{CH}_{4}$ and $\mathrm{N}_{2} \mathrm{O}$ fluxes. Model results from 1981 to 2010 15 were used to analyze the spatial and temporal patterns of global $\mathrm{CH}_{4}$ and $\mathrm{N}_{2} \mathrm{O}$ fluxes in this study.

Two simulation experiments were designed to achieve the study goals: (1) Baseline experiment: transient input data during 1901-1980 for all environmental factors (i.e., climate, land use, nitrogen deposition, ozone pollution, atmospheric $\mathrm{CO}_{2}$ concentration, and nitrogen fertilizer use) were fed into the DLEM model and then kept constant at the level of 1980 thereafter; (2) combined experiment: all environmental factors changed with time during 1901-2010. The effects of multiple environmental changes on $\mathrm{CH}_{4}$ and $\mathrm{N}_{2} \mathrm{O}$ fluxes were the difference between these two experiments. With this experiment design, the legacy effects of environmental factors before 1981 were excluded.
BGD

10, 19811-19865, 2013

Global

land-atmosphere

exchange of methane and nitrous oxide

H. Tian et al.

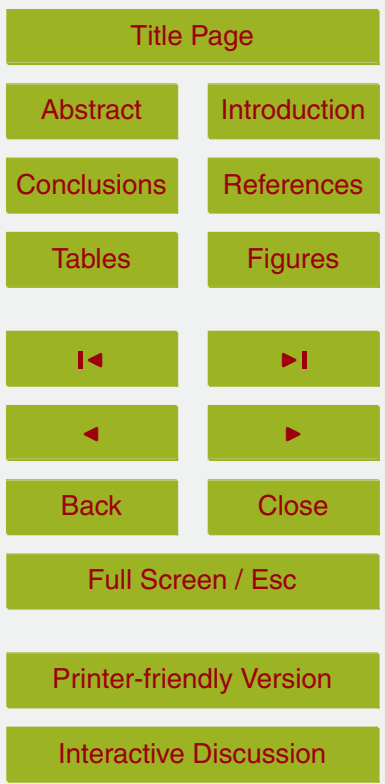




\subsection{Model evaluation and uncertainty analysis}

In this study, we estimated the modeled uncertainty ranges for $\mathrm{CH}_{4}$ and $\mathrm{N}_{2} \mathrm{O}$ resulting from variations in the most sensitive parameters. First, we conducted sensitivity analysis to identify the most sensitive parameters that affect terrestrial $\mathrm{CH}_{4}$ and $\mathrm{N}_{2} \mathrm{O}$

5 fluxes. We selected about 10 parameters related to $\mathrm{CH}_{4}$ and $\mathrm{N}_{2} \mathrm{O}$ fluxes, respectively and assigned a variation range of $\pm 20 \%$ for each parameter. According to the simulation results driven by these individual parameters, we selected the top 5 most sensitive parameters to conduct the uncertainty simulation. Second, we assumed that each parameter follows normal distribution. Combined with the prior knowledge of parameter range, we used improved Latin Hypercube Sampling (LHS) approach to randomly select an ensemble of 100 sets of parameter values to do model simulations. Finally, the outliers for the simulation results were excluded before analyzing the uncertainty range. The $95 \%$ confidence intervals were calculated and reported.

The evaluations of DLEM simulation results against field investigations, regional inventory, and other modeling results for both $\mathrm{CH}_{4}$ and $\mathrm{N}_{2} \mathrm{O}$ fluxes were conducted in our previous studies (Tian et al., 2010, 2011a, 2012b, c; Xu et al., 2010, 2012; Ren et al., 2011 and Melton et al., 2013). These evaluations indicated that DLEM is able to capture the daily, annual, and spatial variation patterns of the observed $\mathrm{CH}_{4}$ and $\mathrm{N}_{2} \mathrm{O}$ fluxes. We showed the DLEM model evaluations (some were from our previous publications) against field experiments or observations worldwide in Table 1. The observed $\mathrm{CH}_{4}$ and $\mathrm{N}_{2} \mathrm{O}$ fluxes showed large variability within and among research sites, indicating the complex impacts of multiple environmental factors on $\mathrm{CH}_{4}$ and $\mathrm{N}_{2} \mathrm{O}$ fluxes. We found that most of the DLEM-simulated $\mathrm{CH}_{4}$ and $\mathrm{N}_{2} \mathrm{O}$ fluxes fell in the observation range for different land cover types (i.e., forest, grassland, wetland, and cropland). We
BGD

10, 19811-19865, 2013

Global

land-atmosphere

exchange of methane and nitrous oxide

H. Tian et al.

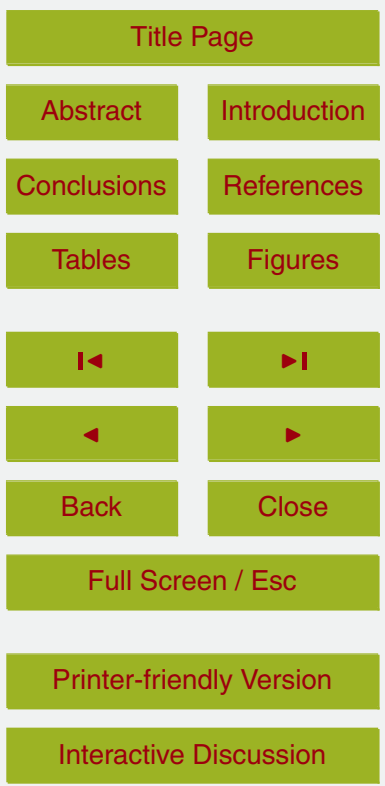




\subsection{Statistical analysis}

The multiple linear regression analyses were conducted to explore the long-term changing trends of input data and $\mathrm{CH}_{4}$ and $\mathrm{N}_{2} \mathrm{O}$ fluxes. The Pearson correlation was conducted to evaluate the correlations between input data and $\mathrm{CH}_{4}$ and $\mathrm{N}_{2} \mathrm{O}$

5 fluxes. All the statistical analyses were conducted by using the software R-program (www.r-project.org); and the figures and maps were generated by Origin 8.0 and ArcGIS 9.2.

\section{Results}

\subsection{Global environmental change over past three decades}

10 From 1981 to 2010 , air temperature and precipitation significantly increased by $0.02^{\circ} \mathrm{Cyr}^{-1}$ and $1.37 \mathrm{~mm} \mathrm{yr}^{-1}$, respectively (Table 2). Nitrogen fertilizer use, nitrogen deposition, atmospheric $\mathrm{CO}_{2}$ concentration, cropland and urban land area continuously increased during the study period. The tropospheric $\mathrm{O}_{3}$ concentration showed a slight increase before 1995 and a fast increase thereafter. Relative to a $30 \mathrm{yr}$ (196115 1990) average, precipitation increased in most areas during the period 1981-2010. The highest increase occurred in the South America, whereas large precipitation decrease was found in the southern Africa, the northern India, and the southeastern Australia (Fig. 2a). Air temperature increased in most areas, with the highest increases in the northern high-latitude region and a slight decrease in the South America and Oceania (Fig. 2b). The highest nitrogen deposition rates were shown in the East and South Asia, while the highest nitrogen fertilizer use rates were shown in the eastern China. These regions experienced fast growth in population, urbanization, and industrialization during the past three decades. The highest tropospheric ozone concentrations in 2005 were distributed along the northern mid-latitude region, such as the southeastern United States, the southern Europe, the central Asia, and the western China.

Global

land-atmosphere

exchange of methane and nitrous oxide

H. Tian et al.

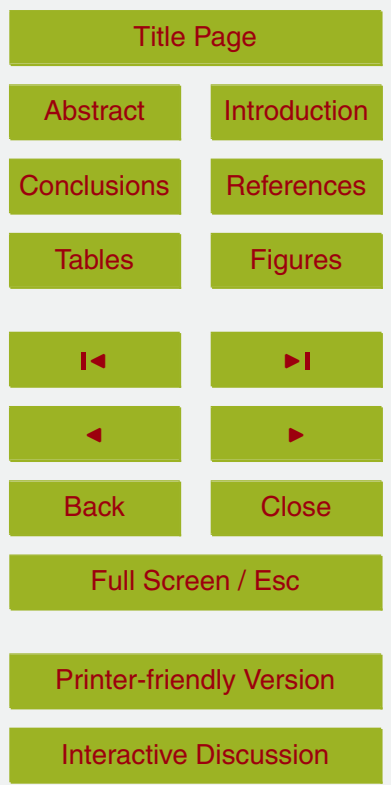


At continental scales, air temperature increased in all continents except for Oceania, with the most rapid increase in Europe and Asia (Table 2). Precipitation significantly increased for Africa and South America, while no significant trends were found for other continents. Nitrogen deposition and $\mathrm{O}_{3}$ concentration (AOT40 index) increased

5 significantly for all continents, with the highest increasing rates in Asia over past three decades. Cropland area significantly changed for all continents, with a decreasing trend found in Europe and North America and rapid increase in Asia and Africa. Cropland fertilizer use significantly increased in the continents other than Europe and the most rapid increase occurred in Asia. Air temperature increased for all climate zones except 10 the southern temperate zone, and the northern polar zone showed the most rapid increase (Table 3). Precipitation increased significantly in the northern polar, northern tropical and southern tropical zones. Nitrogen deposition increased significantly for all continents, with the fastest increase in the northern tropical zone. Cropland nitrogen fertilizer use amounts increased significantly for most climate zones except that the 15 northern polar zone showed a significant decrease. Cropland area decreased significantly in the northern polar and northern temperate zones, while increased significantly in other climate zones, with the most rapid growth in the northern tropical zone. Ozone concentration increased significantly in the tropical and northern temperate zones.

\subsection{Global budget of terrestrial $\mathrm{CH}_{4}$ and $\mathrm{N}_{2} \mathrm{O}$ fluxes}

20 The estimated terrestrial $\mathrm{CH}_{4}$ emission during 1981-2010 was averaged $169.43 \pm 32.92 \mathrm{TgCyr}^{-1}\left(1 \mathrm{Tg}=10^{12} \mathrm{~g}\right)$, ranging from $155.36 \pm 30.05 \mathrm{TgCyr}^{-1}$ in 1982 to

$187.80 \pm 36.19 \mathrm{TgCyr}^{-1}$ in 2010. Among which, the upland soil uptake of $\mathrm{CH}_{4}$ was $17.10 \pm 0.17 \mathrm{TgCyr}^{-1}$. The terrestrial $\mathrm{N}_{2} \mathrm{O}$ emission was aver25 aged $12.52 \pm 1.89 \mathrm{TgNyr}^{-1}$, ranging from $10.53 \pm 1.52 \mathrm{TgNyr}^{-1}$ in 1982 to $16.65 \pm 2.80 \mathrm{TgNyr}^{-1}$ in 2010 (Fig. 3). Both $\mathrm{CH}_{4}$ and $\mathrm{N}_{2} \mathrm{O}$ showed a significant $(P<0.01)$ increasing trend of $0.75 \pm 0.08 \mathrm{TgCyr}^{-1}$ for $\mathrm{CH}_{4}$ and $0.14 \pm 0.02 \mathrm{Tg} \mathrm{Nyr}^{-1}$

BGD

10, 19811-19865, 2013

Global

land-atmosphere

exchange of methane and nitrous oxide

H. Tian et al.

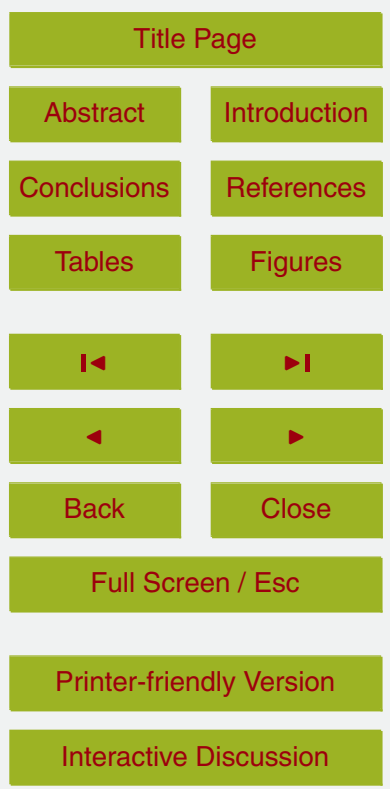


for $\mathrm{N}_{2} \mathrm{O}$ over the study period. The interannual variations in $\mathrm{CH}_{4}$ and $\mathrm{N}_{2} \mathrm{O}$ fluxes were roughly consistent $\left(R^{2}=0.88 ; P<0.01\right)$, indicating a close relationship between $\mathrm{CH}_{4}$ and $\mathrm{N}_{2} \mathrm{O}$ fluxes, which was found to be primarily controlled by climate variability. Significantly positive correlations between air temperature and the model5 estimated $\mathrm{CH}_{4}\left(R^{2}=0.73, P<0.01\right)$ and $\mathrm{N}_{2} \mathrm{O}$ emissions $\left(R^{2}=0.71, P<0.01\right)$ was observed, implying a strong positive feedback between climate warming and $\mathrm{CH}_{4} / \mathrm{N}_{2} \mathrm{O}$ emissions.

In terms of global warming potential (100 yr horizon), the DLEM-estimated global $\mathrm{CH}_{4}$ and $\mathrm{N}_{2} \mathrm{O}$ emissions (i.e., $5.65 \pm 1.10 \mathrm{PgCO}_{2}$ eqyr ${ }^{-1}$ and $10 \quad 5.86 \pm 0.89 \mathrm{PgCO}_{2} \mathrm{eqyr}^{-1}$, respectively) could completely offset the terrestrial $\mathrm{CO}_{2}$ sink $\left(8.3 \pm 4.3 \mathrm{PgCyr}^{-1}\right.$ estimated by multiple process-based models, Le Quéré et al., 2012) over the recent three decades. It implies that global land ecosystem acted as a positive contributor to climate warming.

\subsection{Spatial distribution of terrestrial $\mathrm{CH}_{4}$ and $\mathrm{N}_{2} \mathrm{O}$ fluxes}

15 As expected from the distribution of wetlands and rice paddy fields, the South and Southeast Asia, tropical wetlands and river flood plains (e.g., Amazonia and the Pantanal) were dominant hot-spots of $\mathrm{CH}_{4}$ emission with values as high as $30 \mathrm{~g} \mathrm{Cm}^{-2} \mathrm{yr}^{-1}$ (Fig. 4). In these regions, more $\mathrm{CH}_{4}$ production precursor-DOC was produced due to the higher biomass, primary production, and litter decomposition rate. In contrast, the northern high-latitude region (e.g., Alaska, the northern Canada, West Siberia and the northern Eurasia) that have large wetland areas, were less substantial $\mathrm{CH}_{4}$ emission sources $\left(\sim 10 \mathrm{~g} \mathrm{Cm}^{-2} \mathrm{yr}^{-1}\right)$. Larger $\mathrm{CH}_{4}$ sinks (i.e., $\left.>0.15 \mathrm{~g} \mathrm{Cm}^{-2} \mathrm{yr}^{-1}\right)$ were found in the tropical and subtropical uplands due to more substrate and favorable climate conditions for methanotrophy. Similar to $\mathrm{CH}_{4}, \mathrm{~N}_{2} \mathrm{O}$ released at rates of larger than $0.3 \mathrm{~g} \mathrm{Nm}^{-2} \mathrm{yr}^{-1}$ in most areas of the tropical region as well as intensively fertilized cropland, while smaller emissions occurred in the high-latitude and sparse vegetated area. In general, $\mathrm{N}_{2} \mathrm{O}$ emissions decreased with air temperature from the low- to high-

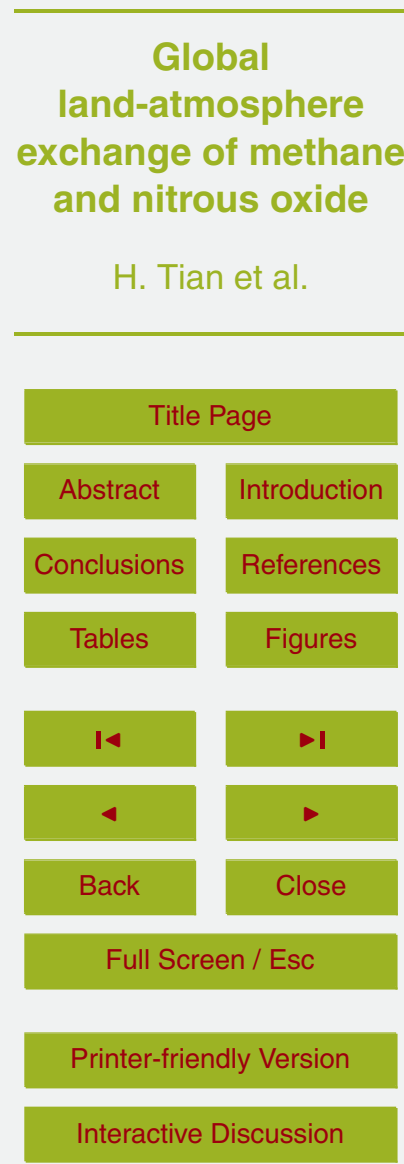


latitude region, indicating air temperature was one of the most important factors controlling $\mathrm{N}_{2} \mathrm{O}$ emissions. To more clearly identify the spatial distribution patterns of $\mathrm{CH}_{4}$ and $\mathrm{N}_{2} \mathrm{O}$ fluxes, we further divided the globe into different latitudinal belts, biome types and continents.

\section{3.4 Terrestrial $\mathrm{CH}_{4}$ and $\mathrm{N}_{2} \mathrm{O}$ fluxes and temporal trends along a latitudinal gradient}

Along the latitudinal gradient, $\mathrm{CH}_{4}$ emissions peaked $\left(8.06 \mathrm{TgCyr}^{-1}\right)$ at the latitudinal zones of $2 \sim 3^{\circ} \mathrm{S}$ and $6 \sim 7^{\circ} \mathrm{S}$ (Fig. 4), primarily due to large wetland area in Amazon river basin. Another smaller peak for $\mathrm{CH}_{4}$ emissions displayed at the northern high10 latitude region (around $60^{\circ} \mathrm{N}$ ). $\mathrm{N}_{2} \mathrm{O}$ emissions peaked at the latitude zone of $6-7^{\circ} \mathrm{N}$ $\left(0.43 \mathrm{TgNyr}^{-1}\right)$, which is primarily due to large area of fertilized cropland. We further grouped the global terrestrial ecosystems into five major climate zones: the northern polar zone $\left(>60^{\circ} \mathrm{N}\right)$, the northern temperate zone $\left(30^{\circ}-60^{\circ} \mathrm{N}\right)$, the northern tropical zone $\left(0^{\circ}-30^{\circ} \mathrm{N}\right)$, the southern tropical zone $\left(0^{\circ}-30^{\circ} \mathrm{S}\right)$, and the southern temperate 15 zone $\left(30^{\circ}-60^{\circ} \mathrm{S}\right)$. All climate zones were net sources of $\mathrm{CH}_{4}$ and $\mathrm{N}_{2} \mathrm{O}$ emissions to the atmosphere (Table 4). The largest $\mathrm{CH}_{4}$ emissions occurred in the southern tropical zone, followed by the northern tropical zone, and the least in the southern temperate zone. The tropical zone (both southern and northern) totally accounted for about $80 \%$ of the total $\mathrm{CH}_{4}$ emissions. The largest $\mathrm{N}_{2} \mathrm{O}$ emissions occurred in the northern tropical zone, followed by the southern tropical zone, and the least was found in the southern temperate zone. The tropical zone also accounted for about $75 \%$ of the total $\mathrm{N}_{2} \mathrm{O}$ emissions.

Our simulation experiments indicated that temporal trends in the $\mathrm{CH}_{4}$ and $\mathrm{N}_{2} \mathrm{O}$ fluxes varied significantly among various climate zones (Fig. 5). Over the study period, the 25 most rapid increase in $\mathrm{CH}_{4}$ emission was observed in northern and southern tropical zone $\left(0.22-0.37 \mathrm{TgCyr}^{-1}\right)$, followed by northern temperate zone $\left(0.12 \mathrm{TgCyr}^{-1}\right)$ and northern polar zone $\left(0.046 \mathrm{TgC} \mathrm{yr}^{-1}\right)$ while no significant changing trend was found

BGD

10, 19811-19865, 2013

Global

land-atmosphere

exchange of methane and nitrous oxide

H. Tian et al.

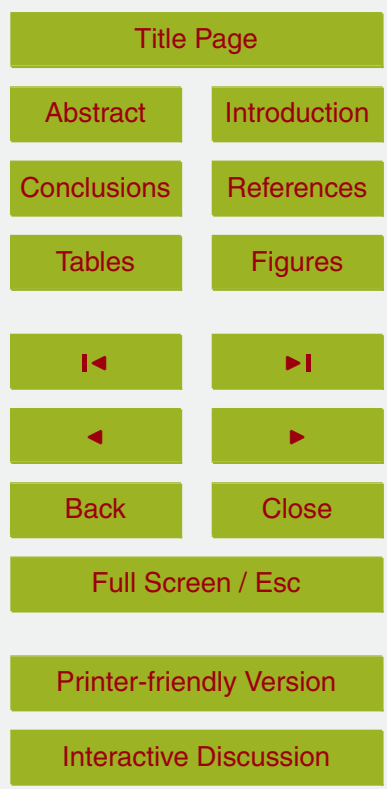


for the southern temperate zone. Similarly, faster increase in the $\mathrm{N}_{2} \mathrm{O}$ emissions has occurred in northern tropical and southern tropical zones $\left(0.039-0.078 \mathrm{TgNyr}^{-1}\right)$ than other zones. No significant changing trend in $\mathrm{N}_{2} \mathrm{O}$ emission was observed for the southern temperate zone; however, larger interannual variations were found in this zone compared to other zones. The highest $\mathrm{CH}_{4}$ and $\mathrm{N}_{2} \mathrm{O}$ emissions occurred in 2010 for all the climate zones except for the northern polar and southern temperate zones.

\subsection{Terrestrial $\mathrm{CH}_{4}$ and $\mathrm{N}_{2} \mathrm{O}$ fluxes and temporal trends for different biome types}

We further compared the magnitude of $\mathrm{CH}_{4}$ and $\mathrm{N}_{2} \mathrm{O}$ fluxes and their temporal trends during 1981-2010 for different biome types (Table 5; Fig. 6). The largest $\mathrm{CH}_{4}$ emissions were from natural wetland $\left(130.74 \mathrm{TgCyr}^{-1}\right)$, followed by cropland $\left(54.37 \mathrm{TgCyr}^{-1}\right)$. The highest $\mathrm{CH}_{4}$ uptake occurred in forest $\left(-6.43 \mathrm{TgCyr}^{-1}\right)$ and shrubland $\left(4.38 \mathrm{TgCyr}^{-1}\right)$. Multiple environmental changes had caused wetland $\mathrm{CH}_{4}$ emissions increased from $129.01 \mathrm{Tg} \mathrm{Cyr}^{-1}$ in 1981 to $137.67 \mathrm{Tg} \mathrm{Cyr}^{-1}$ in 2010 . From 1981 to 2010, forest and shrubland showed a significant $(p<0.05)$ increasing trend in $\mathrm{CH}_{4}$ uptake, with a rate of $0.014 \mathrm{TgCyr}^{-1}$ and $0.0061 \mathrm{TgCyr}^{-1}$, respectively (Fig. 6). Wetlands and rice field showed a more significant $(P<0.01)$ increasing trend in $\mathrm{CH}_{4}$ emission, with a rate of $0.25 \mathrm{TgCyr}^{-1}(P<0.01)$ and $0.54 \mathrm{TgCyr}^{-1}(P<0.01)$, respectively, while no significant change trend was found for grassland. Rice field expansion (15\% as shown in Table 2) contributed to $12 \%$ of cropland $\mathrm{CH}_{4}$ emissions increase and the remaining $88 \%$ increase resulted from other environmental changes including climate, atmospheric composition, and land management practices. It is notable that $\mathrm{CH}_{4}$ uptake in upland ecosystems (i.e., forest, shrubland and grassland) exhibited a faster increase from 2000 to 2010 compared to previous two decades.

25 The largest emissions of $\mathrm{N}_{2} \mathrm{O}$ were from forest $\left(4.28 \mathrm{Tg} \mathrm{Nyr}^{-1}\right)$, followed by cropland $\left(3.36 \mathrm{Tg} \mathrm{Nyr}^{-1}\right)$, and the least was from grassland $\left(0.82 \mathrm{TgNyr}^{-1}\right)$. Most of the forest $\mathrm{N}_{2} \mathrm{O}$ emissions came from tropical region. Compared to forests in other climatic zones,
BGD

10, 19811-19865, 2013

Global

land-atmosphere

exchange of methane and nitrous oxide

H. Tian et al.

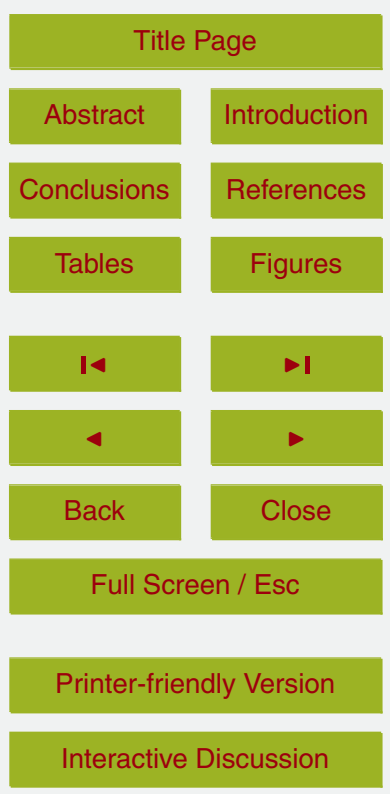


tropical forests had larger area and higher nitrogen transformation rate. Nitrous oxide emissions significantly increased for all the biome types from 1981 to 2010 (Fig. 6). $\mathrm{N}_{2} \mathrm{O}$ emissions kept a slight $(P>0.1)$ increase from 1981 to 2000 for forest, shrubland and grassland, but a significantly faster increase was found during 2000-2010. 5 Cropland displayed the largest increase in $\mathrm{N}_{2} \mathrm{O}$ emission $\left(0.08 \mathrm{TgNyr}^{-1} ; R^{2}=0.93\right.$; $P<0.01$ ), which was primarily due to rapid cropland expansion and increasing nitrogen fertilizer uses (Table 2). Cropland area has expanded by $7.8 \%(\sim 11$ million ha) since 1981, and nitrogen fertilizer uses have increased by $66 \%\left(\sim 33 \mathrm{TgNyr}^{-1}\right)$. Increased nitrogen deposition and air temperature were the major causes of increased $\mathrm{N}_{2} \mathrm{O}$ emissions in the non-managed biomes.

\subsection{Change trends in terrestrial $\mathrm{CH}_{4}$ and $\mathrm{N}_{2} \mathrm{O}$ fluxes for different continents}

At continental scale, significant increasing trends $(p<0.01)$ in $\mathrm{CH}_{4}$ emissions were found for all continents except Africa and Europe (Fig. 7). Asia showed the highest $\mathrm{CH}_{4}$ emission and the most rapid increase $\left(0.56 \mathrm{TgCyr}^{-1}, p<0.01\right) . \mathrm{CH}_{4}$ emissions 15 from Europe showed a large decrease since the early 1990s. Significant increasing trends in $\mathrm{N}_{2} \mathrm{O}$ emissions were found in all continents except Europe and Oceania. $\mathrm{N}_{2} \mathrm{O}$ emissions had no obvious change trend before 2000 in Europe, but a rapid increase occurred since then. The most rapid $\mathrm{N}_{2} \mathrm{O}$ emission increases in Asia $\left(0.056 \mathrm{Tg} \mathrm{Nyr}^{-1}\right.$, $P<0.01$ ) was caused by larger rises in nitrogen fertilizer uses and nitrogen deposition compared to other continents (Table 2). Asia and South America acted as the largest $\mathrm{CH}_{4}$ and $\mathrm{N}_{2} \mathrm{O}$ sources with the highest increasing trends, suggesting that these two continents will continue to play a major role in greenhouse gas budget in the future. It is also notable that the interannual variations of $\mathrm{CH}_{4}$ and $\mathrm{N}_{2} \mathrm{O}$ emissions were very similar $\left(R^{2}=0.89 ; P<0.01\right)$ in Asia, implying a close linkage between these two gases
BGD

10, 19811-19865, 2013

Global

land-atmosphere

exchange of methane and nitrous oxide

H. Tian et al.

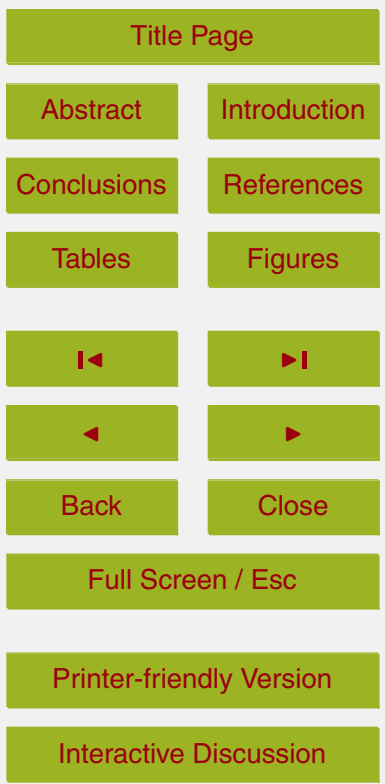




\section{Discussion}

\subsection{Comparisons with other estimation of global $\mathrm{CH}_{4}$ and $\mathrm{N}_{2} \mathrm{O}$ budgets}

The simultaneous estimation of global $\mathrm{CH}_{4}$ and $\mathrm{N}_{2} \mathrm{O}$ fluxes shown in this study were in-line with previous estimates (Table 6). The DLEM-estimated global $\mathrm{CH}_{4}$ flux was

5 157-187 $\mathrm{TgCyr}^{-1}$ for the 1990s, which fell in the range of $86-200 \mathrm{TgCyr}^{-1}$ estimated by other investigators (Fung et al., 1991; Houweling et al., 1999; Ridgwell et al., 1999). This study estimated that the global natural wetland emitted $130.98 \mathrm{TgCyr}^{-1}$ in the 1990s, which is higher than $92 \mathrm{TgCyr}^{-1}$ estimated by Cao et al. (1998), but similar to the estimate by Liu (1996) and slightly lower than the average value from multiple 10 process-based models (142.5 $\mathrm{TgCyr}^{-1}$; Melton et al., 2013). Our study reported that 128.19 $\mathrm{TgCH}_{4}-\mathrm{Cyr}^{-1}$ was released from global natural wetland in the 1980 s, slightly higher than a previous estimate of $110 \mathrm{TgCyr}^{-1}$ (Matthews and Fung, 1987). Our estimated $\mathrm{CH}_{4}$ emission from rice field (51.42-62.4 $\mathrm{TgCyr}^{-1}$ ) was higher than most previous estimates. It might be due to the expanding rice field and other input drivers (e.g., 15 nitrogen fertilizer amounts and nitrogen deposition rate) considered in this study, but omitted in previous work (Cao et al., 1998; Chen and Prinn 2005; Patra et al., 2009). DLEM-estimated upland $\mathrm{CH}_{4}$ uptake during 1996-2005 $\left(-15.01 \sim-13.45 \mathrm{TgC} \mathrm{yr}^{-1}\right)$ was slightly lower than the previous estimates.

In addition to divergent model representation of biogeochemical processes and pa20 rameter values (Meng et al., 2012), different input data might be another reason responsible for the discrepancies among these $\mathrm{CH}_{4}$ estimates (Meng et al., 2012; Ito and Inatomi et al., 2012; Zhu et al., 2011; Melton et al., 2013). For example, knowledge of wetland distribution and area was highly uncertain. Through multiple models comparisons, Melton et al. (2013) reported that the estimate of global wetland area ranged 25 from $7.1 \times 10^{6}$ to $26.9 \times 10^{6} \mathrm{~km}^{2}$. Even the inventory data largely varied among different data sources ranging from $4.3 \times 10^{6}$ to $12.9 \times 10^{6} \mathrm{~km}^{2}$. In the future, there is a necessity to integrate all data sources into a most accurate data set for model use. In addition,
BGD

10, 19811-19865, 2013

Global

land-atmosphere

exchange of methane and nitrous oxide

H. Tian et al

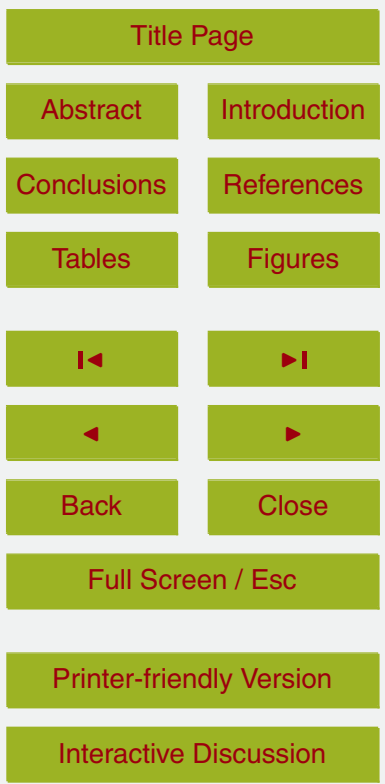


large uncertainty might be also resulted from various climate data. Several series of climate data were previously used by the global models to simulated GHG fluxes. For example, CRU (Mitchell and Jones, 2005), CRUNCEP (Wei et al., 2013) and NCEP reanalysis (Kalnay et al., 1996) data were used by different model simulations (e.g., 5 Bousquet et al., 2011; Ito and Inatomi et al., 2012; Melton et al., 2013).

This study reported global $\mathrm{N}_{2} \mathrm{O}$ emission in a range of $10.49-14.30 \mathrm{TgNyr}^{-1}$ during 1981-2000, which was close to an empirical estimate of $13.31 \mathrm{TgNyr}^{-1}$ (Xu et al., 2008). The estimated $\mathrm{N}_{2} \mathrm{O}$ flux during 1990-1994 (11.51-12.15 $\mathrm{TgNyr}^{-1}$ ) was slightly higher than a process-based modeling result $\left(11.33 \mathrm{TgNyr}^{-1}\right.$; Liu, 1996) and an in10 verse modeling result $\left(9.5 \mathrm{TgNyr}^{-1}\right.$; Nevison et al., 1996). In our study, we considered the manure application (no livestock management), nitrogen fertilizer use, nitrogen deposition, nitrogen fixation and agricultural biomass burning, making our estimated cropland $\mathrm{N}_{2} \mathrm{O}$ flux slightly higher than the estimates from FAO/IFA (2001), Davison (2009) and Bouwman et al. (2002), which did not consider the impacts of nitrogen deposi15 tion and fixation. DLEM-estimated $\mathrm{N}_{2} \mathrm{O}$ emissions from cropland were close to most of previous estimates (e.g., Davison 2009; Bouwman et al., 2002; US EPA 2010). Our estimates for natural land $\mathrm{N}_{2} \mathrm{O}$ emissions were slightly higher than those from Bowden (1986), Saikawa et al. (2013), and US EPA (2010), and significantly higher than the estimate from the statistical extrapolation (Zhuang et al., 2012). DLEM estimated ${ }_{20} \mathrm{~N}_{2} \mathrm{O}$ emission from global grassland and forest were consistent with the empirical extrapolations by Xu et al. (2008) and Zhang et al. (2010). The discrepancies in input datasets and estimation methods might be the major causes of these differences. DLEM used multiple environmental factors, including climate, nitrogen deposition, atmospheric $\mathrm{CO}_{2}$, tropospheric ozone, nitrogen fertilization and land use change, as 25 model input, while most previous studies only considered one or a subset of these factors.
BGD

10, 19811-19865, 2013

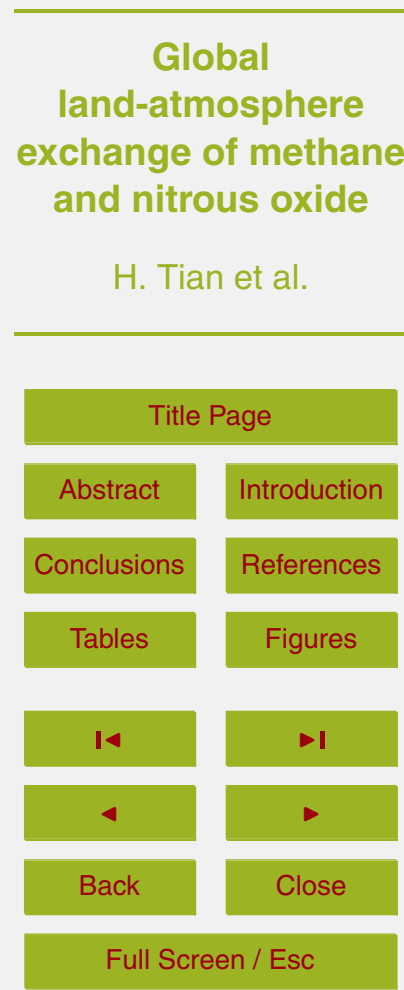

Printer-friendly Version

Interactive Discussion 


\subsection{Regional difference in $\mathrm{CH}_{4}$ and $\mathrm{N}_{2} \mathrm{O}$ fluxes}

Based on measurements and extrapolation, Bartlett and Harriss (1993) and US EPA (1993) estimated that $60.55 \%$ of $\mathrm{CH}_{4}$ emissions were from tropical wetland. Matthews and Fung (1987) estimated that only about $28.83 \%$ was from tropical region, instead, 5 over $58.56 \%$ was from the high-latitude region. However, with the same methods but more observations, Fung et al. (1991) updated their early estimate and reported that about $69.57 \%$ of $\mathrm{CH}_{4}$ emissions were from tropical region. Based on eight processbased ecosystem models, Melton et al. (2013) estimated that about $66.32 \%$ of $\mathrm{CH}_{4}$ emissions were from tropical region. The inverse modeling approach estimated an even higher emission from tropical region (81.01\%, Hein et al., 1997; 83.52\%, Wang et al., $2004 ; 70.75 \%$, Bousquet et al., 2006). Combining all these estimates, US EPA (2010) reached a consensus that about $75 \%$ of $\mathrm{CH}_{4}$ emissions were from the tropical region. Our estimate of $73.92 \%$ (upland $\mathrm{CH}_{4}$ uptake is not separated) is close to this value. The increasing $\mathrm{CH}_{4}$ emission from the northern high latitude and tropical region is also consistent with the estimate from Dlugokencky et al. (2009). We estimated that about $80 \%$ of $\mathrm{N}_{2} \mathrm{O}$ emissions were from the tropical region. Based on observations and inverse methods, Prinn et al. (1990) also reported that $52-68 \%$ of the $\mathrm{N}_{2} \mathrm{O}$ emissions were from the tropical region during 1978-1988. In contrast, using an inversing modeling approach, Hirsch et al. (2006) showed a lower estimate of $\mathrm{N}_{2} \mathrm{O}$ emissions from $30^{\circ} \mathrm{S}$ to $90^{\circ} \mathrm{S}$ ( 0 to $4 \%$ ) and a higher $\mathrm{N}_{2} \mathrm{O}$ emission from $0^{\circ}$ to $30^{\circ} \mathrm{N}$ (50 to $64 \%$ ) during 1998 to 2001.

Due to different spatial and temporal change patterns of multiple environmental factors, the change trends of $\mathrm{CH}_{4}$ and $\mathrm{N}_{2} \mathrm{O}$ fluxes were greatly different among continents and climate zones. In Asia, land cover changed dramatically due to fast-growing population and industrialization during the past three decades and was primarily characterized by conversions of upland natural ecosystems to rice fields, which was the major contributor to the increasing $\mathrm{CH}_{4}$ emission. In addition, nitrogen fertilizer use amount in Asia increased the most rapidly compared to other continents (Table 2) and led to
BGD

10, 19811-19865, 2013

Global

land-atmosphere

exchange of methane and nitrous oxide

H. Tian et al.

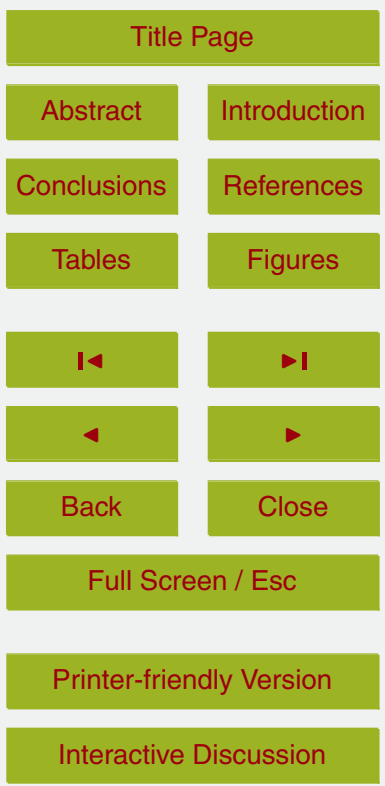


substantial increase in $\mathrm{N}_{2} \mathrm{O}$ emission. Based on inventory data, Kurokawa et al. (2013) found that $\mathrm{CH}_{4}$ and $\mathrm{N}_{2} \mathrm{O}$ increased by $32 \%$ and $18 \%$, respectively from 2000 to 2008 in Asia. By using inversion modeling, Saikawa et al. (2013) also reported that $\mathrm{N}_{2} \mathrm{O}$ emissions from agricultural soil increased by $56 \%\left(0.055 \mathrm{Tgyr}^{-1}\right)$ in Asia (i.e., Northern Asia + Southern Asia) from 1995 to 2008. In North America, land use kept relatively stable and climate variability became the major contributing factors for $\mathrm{CH}_{4}$ emissions, while both climate and nitrogen fertilizer uses contributed the most to $\mathrm{N}_{2} \mathrm{O}$ emissions as indicated by our previous studies (i.e., Tian et al., 2010, 2012b; Xu et al., 2010, 2012a). DLEM simulations in Europe showed a slight decreasing trend in $\mathrm{CH}_{4}$ emission, and a less significant increase in $\mathrm{N}_{2} \mathrm{O}$ compared to other continents. Over shorter period (1990-2011), Saikawa et al. (2013) and EEA (2013) reported that both agricultural and natural soil $\mathrm{N}_{2} \mathrm{O}$ emissions had no significant changing trends in Europe.

\subsection{Climate change and $\mathrm{CH}_{4}$ and $\mathrm{N}_{2} \mathrm{O}$ emissions}

Previous studies indicated that climate variability and change determined inter-annual 15 variations in terrestrial $\mathrm{CH}_{4}$ and $\mathrm{N}_{2} \mathrm{O}$ fluxes (Frolking and Crill, 1994; King, 1997; Xu et al., 2008, 2010, 2012a; Tian et al., 2010; Dijkstra et al., 2012). A field experiment found the hierarchical control on $\mathrm{N}_{2} \mathrm{O}$ emission in forest, and concluded that precipitation controls the instant $\mathrm{N}_{2} \mathrm{O}$ flux pattern while air temperature determines the relatively long-term regime (Brumme et al., 1999). Based on field experiments of 74 plots, Gundersen et al. (2012) found that increased air temperature and precipitation greatly increased $\mathrm{CH}_{4}$ and $\mathrm{N}_{2} \mathrm{O}$ emissions, with stronger impacts from increasing air temperature compared to increasing precipitation. A significant correlation was also found between air temperature and atmospheric $\mathrm{CH}_{4}$ concentration during pre-industrial period (Wuebbles and Hayhoe 2002; Chappellaz et al., 1993a, b). An even stronger positive feedback between $\mathrm{N}_{2} \mathrm{O}$ emissions and air temperature (about $1 \mathrm{TgNyr}^{-1}{ }^{\circ} \mathrm{C}^{-1}$ ) was found by $\mathrm{Xu}$ et al. (2012b). In this study, model simulation also revealed a high correlation $\left(R^{2}=0.73\right.$ for $\mathrm{CH}_{4}$ and 0.71 for $\left.\mathrm{N}_{2} \mathrm{O} ; P<0.01\right)$ between $\mathrm{CH}_{4} / \mathrm{N}_{2} \mathrm{O}$ and
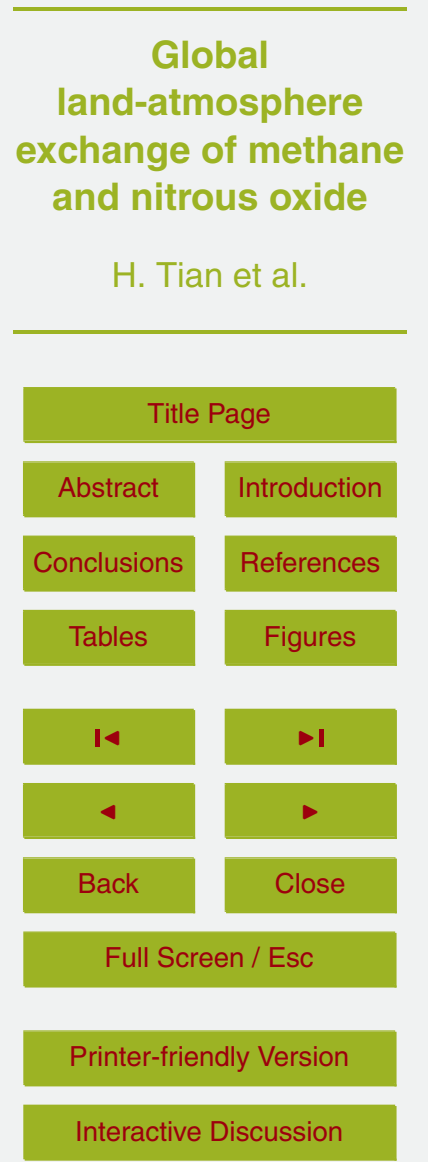

\section{0}


air temperature, implying a strong positive feedback between climate warming and $\mathrm{CH}_{4} / \mathrm{N}_{2} \mathrm{O}$ emissions. Global air temperature significantly increased $\left(0.024^{\circ} \mathrm{C}^{-1}\right.$; Tables 2 and 3) from 1981 to 2010, with the highest increase in the northern polar region $\left(0.039^{\circ} \mathrm{Cyr}^{-1}\right)$. Climate warming in the northern high-latitude region was reported as 5 the most important stimulating factor for increases in atmospheric $\mathrm{CH}_{4}$ and $\mathrm{N}_{2} \mathrm{O}$ (e.g., Mosier et al., 1998; Cantarel et al., 2011; Koven et al., 2011). In our study, we also found that the increases in both $\mathrm{CH}_{4}$ and $\mathrm{N}_{2} \mathrm{O}$ emissions were primarily (>50\%) attributed to air temperature change in the $>60^{\circ} \mathrm{N}$ climatic zone.

\subsection{Temporal trends of $\mathrm{CH}_{4}$ and $\mathrm{N}_{2} \mathrm{O}$ fluxes for different biomes}

10 In this study, we found that the increase in $\mathrm{CH}_{4}$ emissions was primarily due to the effects of multiple environmental changes on wetland and rice paddy land. Multiple environmental changes had led to an increase in natural wetland $\mathrm{CH}_{4}$ emission from $129.01 \mathrm{TgCyr}^{-1}$ in 1981 to $137.67 \mathrm{TgCyr}^{-1}$ in 2010 . Through data synthesis, Kirschke et al. (2013) also found a steady increase in wetland $\mathrm{CH}_{4}$ emission from 151985 to 2010 based on the bottom-up estimation approach, with the highest increase of about $15 \mathrm{TgCyr}^{-1}$ from 1985 to 2010 . We found that rice field area has increased by $0.28 \times 10^{6} \mathrm{~km}^{2}$ from 1981 to 2010 , and $\mathrm{CH}_{4}$ emission from paddy land increased by about $20 \mathrm{TgCyr}^{-1}$ (Fig. 6c). Many previous studies attributed the increased atmospheric $\mathrm{CH}_{4}$ concentration to increased natural wetland emissions (e.g., Chen and

Prinn, 2006; Kirschke et al., 2013; Saikawa et al., 2013), but our study suggested that cropland was among the most important contributors. US EPA (2006) predicted rapid increases in $\mathrm{CH}_{4}$ emissions from rice cultivation from $1990\left(17.64 \mathrm{TgC} \mathrm{yr}^{-1}\right.$ ) to 2010 $\left(20.37 \mathrm{TgC} \mathrm{yr}^{-1}\right)$, with a $15.5 \%$ increase. Kirschke et al. (2013) found an even more rapid increase in natural wetland $\mathrm{CH}_{4}$ emissions from 2005 to 2010, which was also found in our study (Figs. $4 \mathrm{a}$ and $7 \mathrm{c}$ ). For all the upland biomes (i.e., forest, shrubland and grassland), our model estimation showed $\mathrm{CH}_{4}$ uptake increase was larger after 2000 , indicating an acceleration of both $\mathrm{CH}_{4}$ emission and uptake in recent decade.
BGD

10, 19811-19865, 2013

Global

land-atmosphere

exchange of methane and nitrous oxide

H. Tian et al.

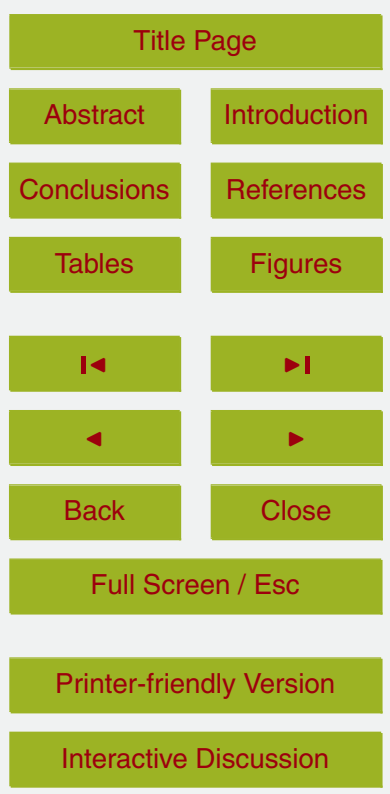


We found that cropland $\mathrm{N}_{2} \mathrm{O}$ emissions constantly increased during 1981-2010, while natural biomes showed a more rapid increase during 2000-2010. By synthesizing most recent studies on global agricultural $\mathrm{N}_{2} \mathrm{O}$ emissions, Reay et al. (2012) and US EPA (2011) indicated that $\mathrm{N}_{2} \mathrm{O}$ emissions from agricultural soil increased by 5 about $1 \mathrm{TgNyr}^{-1}$ from 1990 to 2010 . We had a similar finding with agricultural $\mathrm{N}_{2} \mathrm{O}$ emission increasing by $1.4 \mathrm{TgNyr}^{-1}$ during the same period (Fig. 6e). By using inversion modeling, Saikawa et al. (2013) also estimated an $\mathrm{N}_{2} \mathrm{O}$ emission increase of 1.27 $\mathrm{TgNyr}^{-1}$ (from 2.65 $\mathrm{TgNyr}^{-1}$ in 1995 to $3.92 \mathrm{TgNyr}^{-1}$ in 2008) in global agricultural land. The increases in global cropland area and nitrogen fertilizer amounts, as well as climate change were the major causes for rapid $\mathrm{N}_{2} \mathrm{O}$ emissions increase in cropland (Mosier et al., 1998). Davidson (2009) combined both top-down and bottomup approaches and estimated that about $2.5 \%$ fertilized nitrogen was released during 1860 to 2005. Considering nitrogen fertilizer amount increasing from $\sim 50 \mathrm{TgNyr}^{-1}$ in 1981 to $~ 84 \mathrm{TgNyr}^{-1}$ in 2005, we can conclude that during 1981-2005, increase of 5 about $0.85 \mathrm{Tg} \mathrm{N}_{2} \mathrm{O}-\mathrm{N} \mathrm{yr}^{-1}$ was directly derived from the rising nitrogen fertilizer use. The increases in $\mathrm{N}_{2} \mathrm{O}$ emissions for natural biomes might be primarily due to climate warming and nitrogen deposition. Based on manipulative field experiments, Dijkstra et al. (2012) and Cantarel et al. (2011) found that climate warming significantly increase $\mathrm{N}_{2} \mathrm{O}$ emissions in grassland. Nitrogen deposition could greatly increase carbon 20 storage in the terrestrial ecosystems and in the meanwhile increasing $\mathrm{N}_{2} \mathrm{O}$ emissions for natural biomes (Liu et al., 2009; Lu et al., 2013).

\subsection{Uncertainties and implications}

Due to the complexity of the biogeochemical processes related to $\mathrm{CH}_{4}$ and $\mathrm{N}_{2} \mathrm{O}$ fluxes (Conrad, 1996; Xu et al., 2008; Tian et al., 2012a), some uncertainties need to be considered when interpreting the modeling results. First, uncertainties might be resulted from the simplification of modeling mechanisms for $\mathrm{CH}_{4}$ and $\mathrm{N}_{2} \mathrm{O}$ production and consumption. DLEM runs at daily time step and might miss pulses in $\mathrm{CH}_{4}$ and $\mathrm{N}_{2} \mathrm{O}$ fluxes
BGD

10, 19811-19865, 2013

Global

land-atmosphere

exchange of methane and nitrous oxide

H. Tian et al.

Title Page

Abstract

Conclusions

Tables

Figures

14

4

Back $\rightarrow$

$>$

Close

\section{Full Screen / Esc}

Printer-friendly Version

Interactive Discussion 
at sub-daily scale. These high pulses may substantially contribute to the annual fluxes (Brumme et al., 1999). Studies have found that the actual ebullition process may be different from the mechanisms applied in most current process-based models (Baird et al., 2004; Kellner et al., 2005; Strack et al., 2005). Although these studies pointed 5 out the possible drawbacks of current modeling representations for this process, no more reliable method has been put forward yet. Additional field or experimental investigations are needed to improve model representation of $\mathrm{CH}_{4}$ ebullition. Second, the parameters uncertainties might lead to estimation biases. For example, it is important to take into account differences of $\mathrm{CH}_{4}$ production and oxidation in tropical and north10 ern wetlands, which have not been well documented yet (Blais et al., 2005). Third, the uncertainties in input data also need to be considered. For example, $\mathrm{CH}_{4}$ and $\mathrm{N}_{2} \mathrm{O}$ fluxes have been reported at an order of magnitude difference among different wetland classes (Barlett and Harriss, 1993; Song et al., 2009), thus the small discrepancy in wetland area and wetland classification could lead to a substantial difference in regional estimation. Meanwhile, the varied wetland extent along the study period is one of the major factor influencing inter-annual variation in $\mathrm{CH}_{4}$ fluxes (Ringeval et al., 2010; Melton et al., 2013). As pointed out in a recent model intercomparison project (Wania et al., 2013; Melton et al., 2013), to more accurately simulate $\mathrm{CH}_{4}$ fluxes, current process-based models need to be improved in several aspects including the wetland 20 extent dynamics, hydrological cycle, etc. $\mathrm{N}_{2} \mathrm{O}$ emission from pasture management (i.e., irrigation, fertilization, grazing rotation, etc.) may contribute a great portion to the global $\mathrm{N}_{2} \mathrm{O}$ flux (Ambus and Robertson, 2006; Li et al., 1996); however, it is not considered in our study.

These findings have important implications for mitigation strategies, which include increasing efficiency of nitrogen use in crop production. In our previous studies (Tian et al., 2011a, 2012a; Lu et al., 2012), we found that some regions in the world are suffering from excessive nitrogen input. Less nitrogen input will maintain the same food productivity but reduce the risks for higher $\mathrm{N}_{2} \mathrm{O}$ emissions, as well as soil and water nitrogen pollutions. To slow down future global warming, policy makers should
BGD

10, 19811-19865, 2013

Global

land-atmosphere

exchange of methane and nitrous oxide

H. Tian et al.

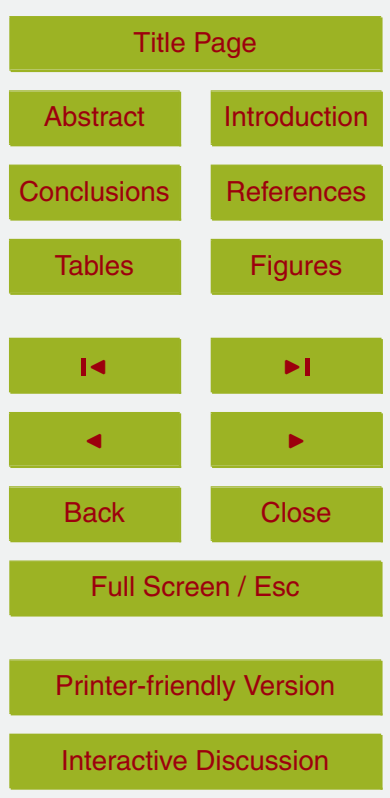


pay special attention to reducing $\mathrm{CH}_{4}$ and $\mathrm{N}_{2} \mathrm{O}$ emissions in the meanwhile increasing carbon sequestration. Currently, many management practices or governmental policies were implemented either for increasing carbon sequestrations or for reducing carbon emissions, such as intensive management in cropland and planted forests, as well as 5 expanding the area of energy crops to produce "clean" energy. These measures may effectively increase carbon sequestration or reduce carbon emission; however, their impacts on $\mathrm{CH}_{4}$ and $\mathrm{N}_{2} \mathrm{O}$ fluxes are still uncertain (Melillo et al., 2009; Murdiyarso et al., 2010; Tian et al., 2012b). Comprehensive considerations for the three most potent gases are necessary before putting forward any management practices or policies over 10 large area. Future studies are also called for simultaneously investigating net fluxes of $\mathrm{CO}_{2}, \mathrm{CH}_{4}$ and $\mathrm{N}_{2} \mathrm{O}$ in both field experiments and regional estimations.

\section{Conclusions}

Based on a process-based ecosystem model, this study concurrently estimated $\mathrm{CH}_{4}$ and $\mathrm{N}_{2} \mathrm{O}$ fluxes in the terrestrial biosphere during 1981-2010. As most of previous studies addressed only one of these gases and include one or a subset of all these environmental factors, our study might significantly contribute to the accurate estimation of global $\mathrm{CH}_{4}$ and $\mathrm{N}_{2} \mathrm{O}$ budgets and spatiotemporal patterns. We found that both $\mathrm{CH}_{4}$ and $\mathrm{N}_{2} \mathrm{O}$ emissions greatly increased from 1981 to 2010 , indicating global environmental changes could greatly increase $\mathrm{CH}_{4}$ and $\mathrm{N}_{2} \mathrm{O}$ emission to the atmosphere,

the highest increasing rate were found in the tropical zone, suggesting this region could be the hot spots for future climate change research. Although climate change also enhanced $\mathrm{CH}_{4}$ and $\mathrm{N}_{2} \mathrm{O}$ emissions in the northern high-latitude region, the increasing rate was much less than that of the tropical region. Methane uptakes slightly increased for

emision greatly in emission greatly increased in the lowland ecosystems (e.g., natural wetland and rice paddy land). $\mathrm{N}_{2} \mathrm{O}$ emission increased in all the ecosystems with the highest increasing
BGD

10, 19811-19865, 2013

Global

land-atmosphere

exchange of methane and nitrous oxide

H. Tian et al.

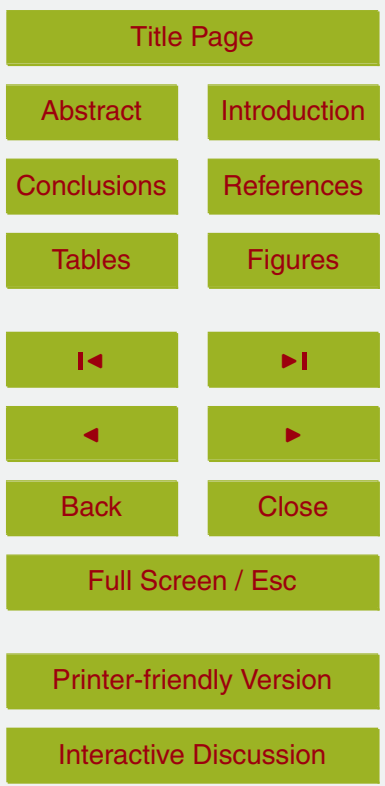


rate found in cropland, which is primarily resulted from cropland management practices (e.g., fertilizer use, irrigation and manure application). Our estimates for global $\mathrm{CH}_{4}$ and $\mathrm{N}_{2} \mathrm{O}$ budgets as well as temporal and spatial variations were consistent with previous field experimental, regional and global studies. High correlations between air 5 temperature and $\mathrm{CH}_{4} / \mathrm{N}_{2} \mathrm{O}$ emissions indicate a positive feedback between climate warming and terrestrial emissions of $\mathrm{CH}_{4}$ and $\mathrm{N}_{2} \mathrm{O}$. Given large increase in $\mathrm{CH}_{4}$ and $\mathrm{N}_{2} \mathrm{O}$ emission at global scale, we suggest that these two gases together with $\mathrm{CO}_{2}$ have to be simultaneously considered when evaluating if a policy is effective or efficient to reduce global warming in the future.

10 Acknowledgements. This study has been supported by NASA Atmospheric Composition: Modeling and Analysis Program (NNH10CC80C), NASA IDS Program (NNX10AU06G, NNG04GM39C), US National Science Foundation Grants (AGS-1243220, CNS-1059376). This study contributes to the Non- $\mathrm{CO}_{2}$ Greenhouse Gases Synthesis of North American Carbon Program (NACP).

\section{References}

Ambus, P. and Robertson, G. P.: Fluxes of $\mathrm{CH}_{4}$ and $\mathrm{N}_{2} \mathrm{O}$ in aspen stands grown under ambient and twice-ambient $\mathrm{CO}_{2}$, Plant Soil, 209, 1-8, 1999.

Baird, A. J., Beckwith, C. W., Waldron, S., and Waddington, J. M.: Ebullition of methanecontaining gas bubbles from near-surface Sphagnum peat, Geophys. Res. Lett., 31, L21505, doi:10.1029/2004GL021157, 2004.

Banger, K., Tian, H., and Lu, C.: Do nitrogen fertilizers stimulate or inhibit methane emissions from rice fields?, Glob. Change Biol., 18, 3259-3267, 2012.

Banin, A.: Global budget of $\mathrm{N}_{2} \mathrm{O}$ : the role of soils and their change, Sci. Total. Environ., 55, 27-38, 1986.

25 Bartlett, K. B. and Harriss, R. C.: Review and assessment of methane emissions from wetlands, Chemosphere, 26, 261-320, 1993.

Bergamaschi, P., Frankenberg, C., Meirink, J. F., Krol, M., Dentener, F., Wagner, T., Platt, U., Kaplan, J. O., Körner, S., Heimann, M., Dlugokencky, E. J., and Goede, A.: Satellite
BGD

10, 19811-19865, 2013

Global

land-atmosphere

exchange of methane

and nitrous oxide

H. Tian et al.

Title Page

Abstract

Introduction

Conclusions

Tables

References

Figures

14

4

Back

Full Screen / Esc

Printer-friendly Version

Interactive Discussion 
chartography of atmospheric methane from SCIAMACHY on board ENVISAT: 2. Evaluation based on inverse model simulations, J. Geophys. Res.-Atmos., 112, D02304, doi:10.1029/2006JD007268, 2007.

Bergamaschi, P., Frankenberg, C., Meirink, J. F., Krol, M., Villani, M. G., Houweling, S., Den5 tener, F., Dlugokencky, E. J., Miller, J. B., Gatti, L. V., Engel, A., and Levin, I.: Inverse modeling of global and regional $\mathrm{CH}_{4}$ emissions using SCIAMACHY satellite retrievals, J. Geophys. Res.-Atmos., 114, D22301, doi:10.1029/2009JD012287, 2009.

Blais, A. M., Lorrain, S., and Tremblay, A.: Greenhouse gas fluxes $\left(\mathrm{CO}_{2}, \mathrm{CH}_{4}\right.$ and $\left.\mathrm{N}_{2} \mathrm{O}\right)$ in forests and wetlands of boreal, temperate and tropical regions, in: Greenhouse Gas Emissions - Fluxes and Processes, edited by: Tremblay, D. A., Varfalvy, D. L., Roehm, D. C., and Garneau, D. M., available at: http://link.springer.com/chapter/10.1007/978-3-540-26643-3_ 5, Springer, Berlin, Heidelberg, 87-127, 2005.

Blankinship, J. C., Brown, J. R., Dijkstra, P., and Hungate, B. A.: Effects of interactive global changes on methane uptake in an annual grassland, J. Geophys. Res.-Biogeo., 115, G02008, doi:10.1029/2009JG001097, 2010.

Bloom, A. A., Palmer, P. I., Fraser, A., Reay, D. S., and Frankenberg, C.: Large-scale controls of methanogenesis inferred from methane and gravity spaceborne data, Science, 327, 322325, 2010.

Bousquet, P., Ciais, P., Miller, J. B., Dlugokencky, E. J., Hauglustaine, D. A., Prigent, C., Van der Werf, G. R., Peylin, P., Brunke, E.-G., Carouge, C., Langenfelds, R. L., Lathière, J., Papa, F., Ramonet, M., Schmidt, M., Steele, L. P., Tyler, S. C., and White, J.: Contribution of anthropogenic and natural sources to atmospheric methane variability, Nature, 443, 439443, doi:10.1038/nature05132, 2006.

Bousquet, P., Ringeval, B., Pison, I., Dlugokencky, E. J., Brunke, E.-G., Carouge, C., Chevallier, F., Fortems-Cheiney, A., Frankenberg, C., Hauglustaine, D. A., Krummel, P. B., Langenfelds, R. L., Ramonet, M., Schmidt, M., Steele, L. P., Szopa, S., Yver, C., Viovy, N., and Ciais, P.: Source attribution of the changes in atmospheric methane for 2006-2008, Atmos. Chem. Phys., 11, 3689-3700, doi:10.5194/acp-11-3689-2011, 2011.

Bouwman, A. F., Boumans, L. J. M., and Batjes, N. H.: Modeling global annual $\mathrm{N}_{2} \mathrm{O}$ and $\mathrm{NO}$ emissions from fertilized fields, Global Biogeochem. Cy., 16, 28-1-28-9, 2002.

Bouwman, A. F., Drecht, G. V., and van der Hoek, K. W.: Surface N balances and reactive N loss to the environment from global intensive agricultural production systems for the period 1970-2030, Sci. China Ser. C, 48, 767-779, 2005.
BGD

10, 19811-19865, 2013

Global

land-atmosphere

exchange of methane

and nitrous oxide

H. Tian et al.

Title Page

Abstract

Introduction

Conclusions

Tables

References

Figures

14

4

Back

Full Screen / Esc

Printer-friendly Version

Interactive Discussion 
Bowden, R. D., Steudler, P. A., Melillo, J. M., and Aber, J. D.: Annual nitrous oxide fluxes from temperate forest soils in the northeastern United States, J. Geophys. Res.-Atmos., 95, 13997-14005, 1990.

Bowden, W. B.: Gaseous nitrogen emissions from undisturbed terrestrial ecosystems: an assessment of their impacts on local and global nitrogen budgets, Biogeochemistry, 2, 249279, doi:10.1007/BF02180161, 1986.

Bronson, K. F., Neue, H.-U., Abao, E. B., and Singh, U.: Automated chamber measurements of methane and nitrous oxide flux in a flooded rice soil: I. Residue, nitrogen, and water management, Soil Sci. Soc. Am. J., 61, 981-987, doi:10.2136/sssaj1997.03615995006100030038x, 101997.

Brumme, R., Borken, W., and Finke, S.: Hierarchical control on nitrous oxide emission in forest ecosystems, Global Biogeochem. Cy., 13, 1137-1148, doi:10.1029/1999GB900017, 1999.

Butterbach-Bahl, K., Gasche, R., Breuer, L., and Papen, $\mathrm{H}$. : Fluxes of $\mathrm{NO}$ and $\mathrm{N}_{2} \mathrm{O}$ from temperate forest soils: impact of forest type, $\mathrm{N}$ deposition and of liming on the $\mathrm{NO}$ and $\mathrm{N}_{2} \mathrm{O}$ emissions, Nutr. Cycl. Agroecosys., 48, 79-90, doi:10.1023/A:1009785521107, 1997.

Cantarel, A. A. M., Bloor, J. M. G., Deltroy, N., and Soussana, J. F.: Effects of climate change drivers on nitrous oxide fluxes in an upland temperate grassland, Ecosystems, 14, 223-33, 2011.

Cao, M., Gregson, K., and Marshall, S.: Global methane emission from wetlands and its sensitivity to climate change, Atmos. Environ., 32, 3293-3299, 1998.

Chen, G., Tian, H., Zhang, C., Liu, M., Ren, W., Zhu, W., Chappelka, A., Prior, S., and Lockaby, G.: Drought in the Southern United States over the 20th century: Variability and its impacts on terrestrial ecosystem productivity and carbon storage, Climatic Change, 114, 379-397, doi:10.1007/s10584-012-0410-z, 2012.

Christensen, T. R., Prentice, I. C., Kaplan, J., Haxeltine, A., and Sitch, S.: Methane flux from northern wetlands and tundra, Tellus B, 48, 652-661, 1996.

Christensen, T. R., Friborg, T., Sommerkorn, M., Kaplan, J., Illeris, L., Soegaard, H., Nordstroem, C., and Jonasson, S.: Trace gas exchange in a high-Arctic valley: 1. Variations in $\mathrm{CO}_{2}$ and $\mathrm{CH}_{4}$ flux between tundra vegetation types, Global Biogeochem. Cy., 14, 701-713, doi:10.1029/1999GB001134, 2000.

Clymo, R. S. and Reddaway, E. J. F.: Productivity of Sphagnum (bog-moss) and peat accumulation, Hydrobiologia, 12, 1-192, 1971.
BGD

10, 19811-19865, 2013

Global

land-atmosphere

exchange of methane

and nitrous oxide

H. Tian et al.

Title Page

Abstract

Introduction

Conclusions

Tables

References

Figures

14

4

Back

Full Screen / Esc

Printer-friendly Version

Interactive Discussion 
Cochran, V. L., Sparrow, E. B., Schlentner, S. F., and Knight, C. W.: Long-term tillage and crop residue management in the subarctic: fluxes of methane and nitrous oxide, Can. J. Soil Sci., 77, 565-570, doi:10.4141/S96-089, 1997.

Conrad, R.: Soil microorganisms as controllers of atmospheric trace gases $\left(\mathrm{H}_{2}, \mathrm{CO}, \mathrm{CH}_{4}, \mathrm{OCS}\right.$, $\mathrm{N}_{2} \mathrm{O}$, and NO), Microbiol. Rev., 60, 609-640, 1996.

Corre, M. D., Pennock, D. J., Kessel, C. V., and Kirkelliott, D.: Estimation of annual nitrous oxide emissions from a transitional grassland-forest region in Saskatchewan, Canada, Biogeochemistry, 44, 29-49, doi:10.1007/BF00992997, 1999.

Dacey, J. W. H., Drake, B. G., and Klug, M. J.: Stimulation of methane emission by carbon dioxide enrichment of marsh vegetation, Nature, 370, 47-49, 1994.

Dambreville, C., Morvan, T., and Germon, J.-C.: $\mathrm{N}_{2} \mathrm{O}$ emission in maize-crops fertilized with pig slurry, matured pig manure or ammonium nitrate in Brittany, Agr. Ecosyst. Environ., 123, 201-210, 2008.

Davidson, E. A.: The contribution of manure and fertilizer nitrogen to atmospheric nitrous oxide since 1860, Nat. Geosci., 2, 659-662, doi:10.1038/ngeo608, 2009.

Davidson, E. A., Matson, P. A., Vitousek, P. M., Riley, R., Dunkin, K., Garcia-Mendez, G., and Maass, J. M.: Processes regulating soil emissions of $\mathrm{NO}$ and $\mathrm{N}_{2} \mathrm{O}$ in a seasonally dry tropical forest, Ecology, 74, 130-139, doi:10.2307/1939508, 1993.

Davidson, E. A., Nepstad, D. C., Ishida, F. Y., and Brando, P. M.: Effects of an experimental drought and recovery on soil emissions of carbon dioxide, methane, nitrous oxide, and nitric oxide in a moist tropical forest, Glob. Change Biol., 14, 2582-2590, 2008.

De Fries, R. S., Hansen, M., Townshend, J. R. G., and Sohlberg, R.: Global land cover classifications at $8 \mathrm{~km}$ spatial resolution: the use of training data derived from Landsat imagery in decision tree classifiers, Int. J. Remote Sens., 19, 3141-3168, doi:10.1080/014311698214235, 1998.

De Laune, R. D., Smith, C. J., and Patrick, W. H.: Methane release from Gulf coast wetlands, Tellus B, 35, 8-15, 1983.

Del Grosso, S. J., Parton, W. J., Mosier, A. R., Walsh, M. K., Ojima, D. S., and Thornton, P. E.: DAYCENT national-scale simulations of nitrous oxide emissions from cropped soils in the

30 United States, J. Environ. Qual., 35, 1451, doi:10.2134/jeq2005.0160, 2006.

Del Grosso, S. J., Ogle, S. M., Parton, W. J., and Breidt, F. J.: Estimating uncertainty in $\mathrm{N}_{2} \mathrm{O}$ emissions from US cropland soils, Global Biogeochem. Cy., 24, GB1009, doi:10.1029/2009GB003544, 2010.

Global

land-atmosphere

exchange of methane and nitrous oxide

H. Tian et al.

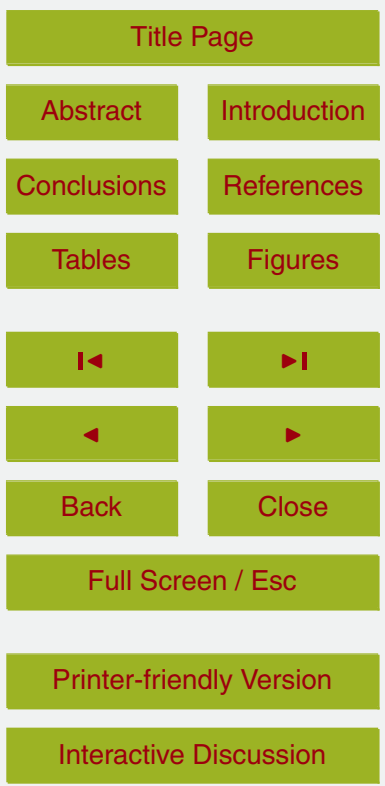


Denman, K. L., Brasseur, G., Chidthaisong, A., Ciais, P., Cox, P. M., Dickinson, R. E., Hauglustaine, D., Heinze, C., Holland, E., Jacob, D., Lohmann, U., Ramachandran, S., da Silva Dias, P. L., Wofsy, S. C., and Zhang, X.: Couplings Between Changes in the Climate System and Biogeochemistry, in: Climate Change 2007: The Physical Science Basis, Contribution of Working Group I to the Fourth Assessment Report of the Intergovernmental Panel on Climate Change edited by: Solomon, S., Qin, D., Manning, M., Chen, Z., Marquis, M., Averyt, K. B., Tignor, M., and Miller, H. L., Cambridge University Press, Cambridge, United Kingdom and New York, NY, USA. 2007.

Dentener, F. J.: Global Maps of Atmospheric Nitrogen Deposition, 1860, 1993, and 2050, Data set, available at: http://daac.ornl.gov/ from Oak Ridge National Laboratory Distributed Active Archive Center, Oak Ridge, Tennessee, USA, doi:10.3334/ORNLDAAC/830, 2006.

Dijkstra, F. A., Prior, S. A., Runion, G. B., Torbert, H. A., Tian, H., Lu, C., and Venterea, R. T.: Effects of elevated carbon dioxide and increased temperature on methane and nitrous oxide fluxes: evidence from field experiments, Front. Ecol. Environ., 10, 520-527, doi:10.1890/120059, 2012.

Dise, N. B.: Methane emission from Minnesota peatlands: spatial and seasonal variability, Global Biogeochem. Cy., 7, 123-142, doi:10.1029/92GB02299, 1993.

Dlugokencky, E. J., Bruhwiler, L., White, J. W. C., Emmons, L. K., Novelli, P. C., Montzka, S. A., Masarie, K. A., Lang, P. M., Crotwell, A. M., Miller, J. B., and Gatti, L. V.: Observational constraints on recent increases in the atmospheric $\mathrm{CH}_{4}$ burden, Geophys. Res. Lett., 36, L18803, doi:10.1029/2009GL039780, 2009.

EEA (European Environment Agency): Annual European Union Greenhouse Gas Inventory 1990-2011 and inventory report 2013, Technical report No 8/2013, available at: http://www. eea.europa.eu/publications/european-union-greenhouse-gas-inventory-2013, 2013.

Erickson, H., Davidson, E. A., and Keller, M.: Former land-use and tree species affect nitrogen oxide emissions from a tropical dry forest, Oecologia, 130, 297-308, 2002.

Ettwig, K. F., Butler, M. K., Le Paslier, D., Pelletier, E., Mangenot, S., Kuypers, M. M. M., Schreiber, F., Dutilh, B. E., Zedelius, J., de Beer, D., Gloerich, J., Wessels, H. J. C. T., van Alen, T., Luesken, F., Wu, M. L., van de Pas-Schoonen, K. T., Op den Camp, H. J. M., Janssen-Megens, E. M., Francoijs, K.-J., Stunnenberg, H., Weissenbach, J., Jetten, M. S. M., and Strous, M.: Nitrite-driven anaerobic methane oxidation by oxygenic bacteria, Nature, 464, 543-548, doi:10.1038/nature08883, 2010.
BGD

10, 19811-19865, 2013

Global

land-atmosphere

exchange of methane

and nitrous oxide

H. Tian et al.

Title Page

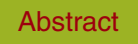

Introduction

Conclusions

Tables

References

Figures

14

4

Back

Close

Full Screen / Esc

Printer-friendly Version

Interactive Discussion 
FAO/IFA: Global Estimates of Gaseous Emissions of $\mathrm{NH}_{3}$, $\mathrm{NO}$ and $\mathrm{N}_{2} \mathrm{O}$ from Agricultural Land, Food and Agriculture Organization of the United Nations (FAO)/International Fertilizer Industry Association (IFA), Rome, 106, 2001

Flessa, $\mathrm{H}$., Dörsch, P., and Beese, F.: Seasonal variation of $\mathrm{N}_{2} \mathrm{O}$ and $\mathrm{CH}_{4}$ fluxes in differently 5 managed arable soils in southern Germany, J. Geophys. Res.-Atmos., 100, 23115-23124, doi:10.1029/95JD02270, 1995.

Forster, P., Ramaswamy, V., Artaxo, P., Berntsen, T., Betts, R., Fahey, D. W., Haywood, J., Lean, J., Lowe, D. C., Myhre, G., Nganga, J., Prinn, R., Raga, G., Schultz, M., and Van Dorland, R.: Changes in Atmospheric Constituents and in Radiative Forcing, available at: http: //www.ipcc.ch/pdf/assessment-report/ar4/wg1/ar4-wg1-chapter2.pdf, Cambridge University Press, Cambridge, UK, 2007.

Frankenberg, C., Meirink, J. F., Weele, M. van, Platt, U., and Wagner, T.: Assessing methane emissions from global space-borne observations, Science, 308, 1010-1014, doi:10.1126/science.1106644, 2005.

Frolking, S. and Crill, P.: Climate controls on temporal variability of methane flux from a poor fen in southeastern New Hampshire: measurement and modeling, Global Biogeochem. Cy., 8, 385-397, doi:10.1029/94GB01839, 1994.

Fung, I., John, J., Lerner, J., Matthews, E., Prather, M., Steele, L. P., and Fraser, P. J.: Threedimensional model synthesis of the global methane cycle, J. Geophys. Res.-Atmos., 96,

20 13033-13065, doi:10.1029/91JD01247, 1991.

Garcia-Montiel, D. C., Steudler, P. A., Piccolo, M., Neill, C., Melillo, J., and Cerri, C. C.: Nitrogen oxide emissions following wetting of dry soils in forest and pastures in Rondônia, Brazil, Biogeochemistry, 64, 319-336, doi:10.1023/A:1024968802018, 2003.

Goodroad, L. L. and Keeney, D. R.: Nitrous oxide production in aerobic soils under varying pH, temperature and water content, Soil Biol. Biochem., 16, 39-43, 1984.

Hadi, A., Inubushi, K., and Yagi, K.: Effect of water management on greenhouse gas emissions and microbial properties of paddy soils in Japan and Indonesia, Paddy Water Environ., 8, 319-324, doi:10.1007/s10333-010-0210-x, 2010.

Hao, X., Chang, C., Carefoot, J. M., Janzen, H. H., and Ellert, B. H.: Nitrous oxide emissions from an irrigated soil as affected by fertilizer and straw management, Nutr. Cycl. Agroecosys., 60, 1-8, 2001.

Harriss, R. C., Gorham, E., Sebacher, D. I., Bartlett, K. B., and Flebbe, P. A.: Methane flux from northern peatlands, Nature, 315, 652-654, doi:10.1038/315652a0, 1985.

Global

land-atmosphere

exchange of methane and nitrous oxide

H. Tian et al.

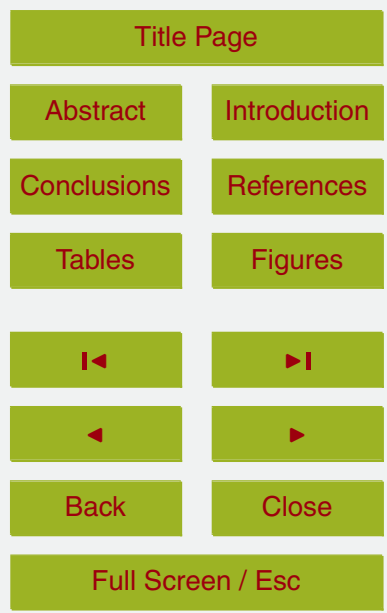

Printer-friendly Version

Interactive Discussion 
Hendriks, D. M. D., van Huissteden, J., Dolman, A. J., and van der Molen, M. K.: The full greenhouse gas balance of an abandoned peat meadow, Biogeosciences, 4, 411-424, doi:10.5194/bg-4-411-2007, 2007.

Hirsch, A. I., Michalak, A. M., Bruhwiler, L. M., Peters, W., Dlugokencky, E. J., and Tans, P. P.: Inverse modeling estimates of the global nitrous oxide surface flux from 1998-2001, Global Biogeochem. Cy., 20, GB1008, doi:10.1029/2004GB002443, 2006.

Hou, H., Peng, S., Xu, J., Yang, S., and Mao, Z.: Seasonal variations of $\mathrm{CH}_{4}$ and $\mathrm{N}_{2} \mathrm{O}$ emissions in response to water management of paddy fields located in southeast China, Chemosphere, 89, 884-892, 2012.

10 Houweling, S., Kaminski, T., Dentener, F., Lelieveld, J., and Heimann, M.: Inverse modeling of methane sources and sinks using the adjoint of a global transport model, J. Geophys. Res.-Atmos., 104, 26137-26160, 1999.

Huang, J., Golombek, A., Prinn, R., Weiss, R., Fraser, P., Simmonds, P., Dlugokencky, E. J., Hall, B., Elkins, J., Steele, P., Langenfelds, R., Krummel, P., Dutton, G., and Porter, L.: Estimation of regional emissions of nitrous oxide from 1997 to 2005 using multinetwork measurements, a chemical transport model, and an inverse method, J. Geophys. Res.-Atmos., 113, D17313, doi:10.1029/2007JD009381, 2008.

Huang, Y., Sun, W., Zhang, W., Yu, Y., Su, Y., and Song, C.: Marshland conversion to cropland in northeast China from 1950 to 2000 reduced the greenhouse effect, Glob. Change Biol., 16, 680-695, 2010.

Hutchin, P. R., Press, M. C., Lee, J. A., and Ashenden, T. W.: Elevated concentrations of $\mathrm{CO}_{2}$ may double methane emissions from mires, Glob. Change Biol., 1, 125-128, doi:10.1111/j.1365-2486.1995.tb00012.x, 1995.

Ineson, P., Coward, P. A., and Hartwig, U. A.: Soil gas fluxes of $\mathrm{N}_{2} \mathrm{O}, \mathrm{CH}_{4}$ and $\mathrm{CO}_{2}$ beneath Lolium perenne under elevated $\mathrm{CO}_{2}$ : the Swiss Free Air Carbon Dioxide Enrichment Experiment, Plant Soil, 198, 89-95, doi:10.1023/A:1004298309606, 1998.

Ito, A. and Inatomi, M.: Use of a process-based model for assessing the methane budgets of global terrestrial ecosystems and evaluation of uncertainty, Biogeosciences, 9, 759-773, doi:10.5194/bg-9-759-2012, 2012.

so Kalnay, E., Kanamitsu, M., Kistler, R., Collins, W., Deaven, D., Gandin, L., Iredell, M., Saha, S., White, G., Woollen, J., Zhu, Y., Leetmaa, A., Reynolds, R., Chelliah, M., Ebisuzaki, W., Higgins, W., Janowiak, J., Mo, K. C., Ropelewski, C., Wang, J., Jenne, R., and Joseph, D.: The NCEP/NCAR 40-year reanalysis project, B. Am. Meteorol. Soc., 77, 437-471, 1996.
BGD

10, 19811-19865, 2013

Global

land-atmosphere

exchange of methane

and nitrous oxide

H. Tian et al.

Title Page

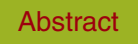

Introduction

Conclusions

Tables

References

Figures

14

4

Back

Full Screen / Esc

Printer-friendly Version

Interactive Discussion 
Kanerva, T., Palojärvi, A., Rämö, K., and Manninen, S.: Changes in soil microbial community structure under elevated tropospheric $\mathrm{O}_{3}$ and $\mathrm{CO}_{2}$, Soil Biol. Biochem., 40, 2502-2510, 2008.

Keller, M. and Reiners, W. A.: Soil-atmosphere exchange of nitrous oxide, nitric oxide, and 5 methane under secondary succession of pasture to forest in the Atlantic lowlands of Costa Rica, Global Biogeochem. Cy., 8, 399-409, doi:10.1029/94GB01660, 1994.

Keller, M., Goreau, T. J., Wofsy, S. C., Kaplan, W. A., and McElroy, M. B.: Production of nitrous oxide and consumption of methane by forest soils, Geophys. Res. Lett., 10, 1156-1159, doi:10.1029/GL010i012p01156, 1983.

10 Kellner, E., Waddington, J. M., and Price, J. S.: Dynamics of biogenic gas bubbles in peat: potential effects on water storage and peat deformation, Water Resour. Res., 41, W08417, doi:10.1029/2004WR003732, 2005.

Kessavalou, A., Doran, J. W., Mosier, A. R., and Drijber, R. A.: Greenhouse gas fluxes following tillage and wetting in a wheat-fallow cropping system, J. Environ. Quality, 27, 1105-1116, 151998.

Kettunen, R., Saarnio, S., Martikainen, P., and Silvola, J.: Elevated $\mathrm{CO}_{2}$ concentration and nitrogen fertilization effects on $\mathrm{N}_{2} \mathrm{O}$ and $\mathrm{CH}_{4}$ fluxes and biomass production of Phleum pratense on farmed peat soil, Soil Biol. Biochem., 37, 739-750, 2005.

King, G.: Responses of atmospheric methane consumption by soils to global climate change, Glob. Change Biol., 3, 351-362, 1997.

Kirschke, S., Bousquet, P., Ciais, P., Saunois, M., Canadell, J. G., Dlugokencky, E. J., Bergamaschi, P., Bergmann, D., Blake, D. R., Bruhwiler, L., Cameron-Smith, P., Castaldi, S., Chevallier, F., Feng, L., Fraser, A., Heimann, M., Hodson, E. L., Houweling, S., Josse, B., Fraser, P. J., Krummel, P. B., Lamarque, J. F., Langenfelds, R. L., Le Quéré, C., Naik, V., O'Doherty, S., Palmer, P. I., Pison, I., Plummer, D., Poulter, B., Prinn, R. G., Rigby, M., Ringeval, B., Santini, M., Schmidt, M., Shindell, D. T., Simpson, I. J., Spahni, R., Steele, L. P., Strode, S. A., Sudo, K., Szopa, S., van der Werf, G. R., Voulgarakis, A., van Weele, M., Weiss, R. F., Williams, J. E., and Zeng, G.: Three decades of global methane sources and sinks, Nat. Geosci., 6, 813-823, doi:10.1038/ngeo1955, 2013.

30 Klein, G. K. and van Drecht, G. (Eds.): HYDE 3: Current and Historical Population and Land Cover MNP, Netherlands Environmental Assessment Agency (MN), Bilthoven, the Netherlands, 2006

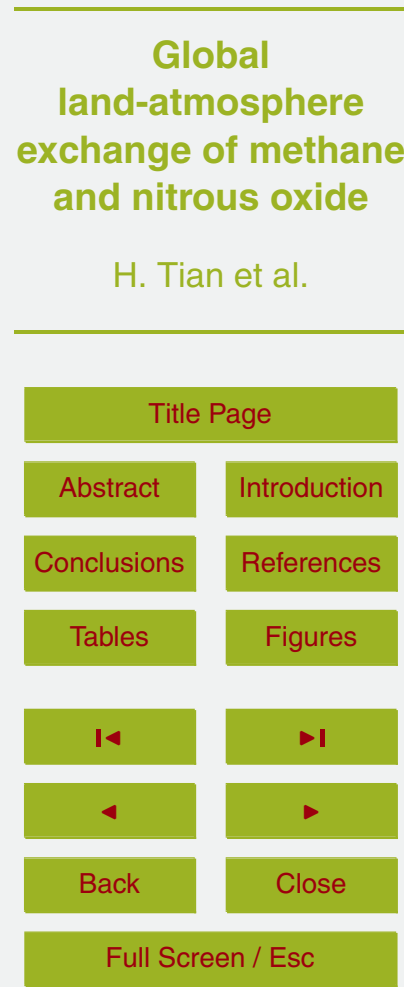

Printer-friendly Version

Interactive Discussion 
Koehler, B., Corre, M. D., Veldkamp, E., Wullaert, H., and Wright, S. J.: Immediate and long term nitrogen oxide emissions from tropical forest soils exposed to elevated nitrogen input, Glob. Change Biol., 15, 2049-2066, 2009.

Kort, E. A., Eluszkiewicz, J., Stephens, B. B., Miller, J. B., Gerbig, C., Nehrkorn, T., Daube, B. C., 5 Kaplan, J. O., Houweling, S., and Wofsy, S. C.: Emissions of $\mathrm{CH}_{4}$ and $\mathrm{N}_{2} \mathrm{O}$ over the United States and Canada based on a receptor-oriented modeling framework and COBRA NA atmospheric observations, Geophys. Res. Lett., 35, L18808, doi:10.1029/2008GL034031, 2008.

Le Quéré, C., Andres, R. J., Boden, T., Conway, T., Houghton, R. A., House, J. I., Marland, G., Peters, G. P., van der Werf, G. R., Ahlström, A., Andrew, R. M., Bopp, L., Canadell, J. G., Ciais, P., Doney, S. C., Enright, C., Friedlingstein, P., Huntingford, C., Jain, A. K., Jourdain, C., Kato, E., Keeling, R. F., Klein Goldewijk, K., Levis, S., Levy, P., Lomas, M., Poulter, B., Raupach, M. R., Schwinger, J., Sitch, S., Stocker, B. D., Viovy, N., Zaehle, S., and Zeng, N.: The global carbon budget 1959-2011, Earth Syst. Sci. Data, 5, 165-185, doi:10.5194/essd-5165-2013, 2013.

Lehner, B. and Döll, P.: Development and validation of a global database of lakes, reservoirs and wetlands, J. Hydrol., 296, 1-22, 2004.

Lemke, R. L., Izaurralde, R. C., Malhi, S. S., Arshad, M. A., and Nyborg, M.: Division S-8 nutrient management \& soil \& plant analysis - nitrous oxide emissions from agricultural soils of the boreal and parkland regions of Alberta, Soil Sci. Soc. Am. J., 62, 1096-1102, 1998.

$20 \mathrm{Li}, \mathrm{C}$., Narayanan, V., and Harriss, R. C.: Model estimates of nitrous oxide emissions from agricultural lands in the United States, Global Biogeochem. Cy., 10, 297-306, doi:10.1029/96GB00470, 1996.

Liu, L. L. and Greaver, T. L.: A review of nitrogen enrichment effects on three biogenic GHGs: the $\mathrm{CO}_{2}$ sink may be largely offset by stimulated $\mathrm{N}_{2} \mathrm{O}$ and $\mathrm{CH}_{4}$ emission, Ecol. Lett., 12, $25 \quad 1103-1117,2009$.

Liu, M., Tian, H., Chen, G., Ren, W., Zhang, C., and Liu, J.: Effects of land-use and land-cover change on evapotranspiration and water yield in China during 1900-2001, J. Am. Water Resour. As., 44, 1193-1207, 2008.

Lu, C. and Tian, H.: Spatial and temporal patterns of nitrogen deposition in China: synthesis 30 of observational data, J. Geophys. Res.-Atmos., 112, D22S05, doi:10.1029/2006JD007990, 2007.
BGD

10, 19811-19865, 2013

Global

land-atmosphere

exchange of methane

and nitrous oxide

H. Tian et al.

Title Page

Abstract

Introduction

Conclusions

Tables

References

Figures

14

4

Back

Close

Full Screen / Esc

Printer-friendly Version

Interactive Discussion 
Lu, C. and Tian, $H_{\text {.: }}$ Net greenhouse gas balance in response to nitrogen enrichment: perspectives from a coupled biogeochemical model, Glob. Change Biol., 19, 571-588, doi:10.1111/gcb.12049, 2013.

Lu, C., Tian, H., Liu, M., Ren, W., Xu, X., Chen, G., and Zhang, C.: Effect of nitrogen deposition on China's terrestrial carbon uptake in the context of multifactor environmental changes, Ecol. Appl., 22, 53-75, 2012.

Matson, A., Pennock, D., and Bedard-Haughn, A.: Methane and nitrous oxide emissions from mature forest stands in the boreal forest, Saskatchewan, Canada, Forest Ecol. Manag., 258, 1073-1083, 2009.

10 Matson, P. A., Vitousek, P. M., Livingston, G. P., and Swanberg, N. A.: Sources of variation in nitrous oxide flux from Amazonian ecosystems, J. Geophys. Res.-Atmos., 95, 16789-16798, 1990.

Matthews, E. and Fung, I.: Methane emission from natural wetlands: global distribution, area, and environmental characteristics of sources, Global Biogeochem. Cy., 1, 61-86, 1987.

Melillo, J. M., Reilly, J. M., Kicklighter, D. W., Gurgel, A. C., Cronin, T. W., Paltsev, S., Felzer, B. S., Wang, X., Sokolov, A. P., and Schlosser, C. A.: Indirect emissions from biofuels: how important?, Science, 326, 1397-1399, 2009.

Melton, J. R., Wania, R., Hodson, E. L., Poulter, B., Ringeval, B., Spahni, R., Bohn, T., Avis, C. A., Beerling, D. J., Chen, G., Eliseev, A. V., Denisov, S. N., Hopcroft, P. O., Lettenmaier, D. P., Riley, W. J., Singarayer, J. S., Subin, Z. M., Tian, H., Zürcher, S., Brovkin, V., van Bodegom, P. M., Kleinen, T., Yu, Z. C., and Kaplan, J. O.: Present state of global wetland extent and wetland methane modelling: conclusions from a model inter-comparison project (WETCHIMP), Biogeosciences, 10, 753-788, doi:10.5194/bg-10-753-2013, 2013.

Mitchell, T. D. and Jones, P. D.: An improved method of constructing a database of monthly climate observations and associated high-resolution grids, Int. J. Climatol.m 25, 693-712, doi:10.1002/joc.1181, 2005.

Montzka, S. A., Dlugokencky, E. J., and Butler, J. H.: Non- $\mathrm{CO}_{2}$ greenhouse gases and climate change, Nature, 476, 43-50, 2011.

Moore, T., Roulet, N., and Knowles, R.: Spatial and temporal variations of methane flux from subarctic/northern boreal fens, Global Biogeochem. Cy., 4, 29-46, 1990.

Mosier, A. R. and Hutchinson, G. L.: Nitrous oxide emissions from cropped fields, J. Environ. Quality, 10, 169, 1981.

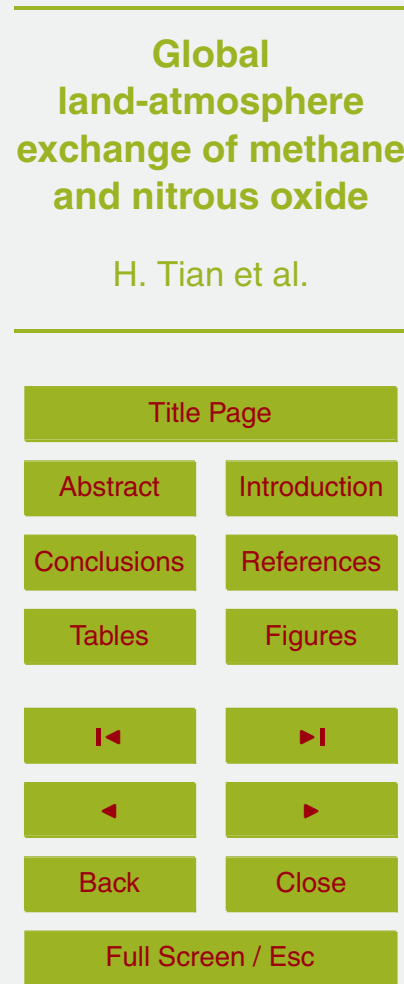

Printer-friendly Version

Interactive Discussion 
Mosier, A. R., Hutchinson, G. L., Sabey, B. R., and Baxter, J.: Nitrous Oxide Emissions from Barley Plots Treated with Ammonium Nitrate or Sewage Sludge, J. Environ. Quality, 11, 7881, doi:10.2134/jeq1982.00472425001100010019x, 1982.

Mosier, A. R., Guenzi, W. D., and Schweizer, E. E.: Soil losses of dinitrogen and nitrous oxide $5 \quad$ from irrigated crops in northeastern Colorado, Soil Sci. Soc. Am. J., 50, 344-348, 1986.

Mosier, A., Schimel, D., Valentine, D., Bronson, K., and Parton, W.: Methane and nitrous oxide fluxes in native, fertilized and cultivated grasslands, Nature, 350, 330-332, 1991.

Mosier, A. R., Delgado, J. A., and Keller, M.: Methane and nitrous oxide fluxes in an acid Oxisol in western Puerto Rico: effects of tillage, liming and fertilization, Soil Biol. Biochem., 30, $10 \quad$ 2087-2098, 1998.

Mosier, A. R., Morgan, J. A., King, J. Y., LeCain, D., and Milchunas, D. G.: Soil-atmosphere exchange of $\mathrm{CH}_{4}, \mathrm{CO}_{2}$, NOx, and $\mathrm{N}_{2} \mathrm{O}$ in the Colorado shortgrass steppe under elevated $\mathrm{CO}_{2}$, Plant Soil, 240, 201-211, 2002.

Murdiyarso, D., Hergoualc'h, K., and Verchot, L. V.: Opportunities for reducing greenhouse gas 15

Pancotto, V. A., van Bodegom, P. M., van Hal, J., van Logtestijn, R. S. P., Blokker, P., Toet, S., and Aerts, R.: $\mathrm{N}$ deposition and elevated $\mathrm{CO}_{2}$ on methane emissions: differential responses of indirect effects compared to direct effects through litter chemistry feedbacks, J. Geophys. Res.-Biogeo., 115, G02001, doi:10.1029/2009JG001099, 2010.

Peng, S., Hou, H., Xu, J., Mao, Z., Abudu, S., and Luo, Y.: Nitrous oxide emissions from paddy fields under different water managements in southeast China, Paddy Water Environ., 9, 403411, doi:10.1007/s10333-011-0275-1, 2011.

Pérez, M. V. A., Castañeda, J. G., Frías-Hernández, J. T., Franco-Hernández, O., Cleemput, O. V., Dendooven, L., and Olalde, V.: Trace gas emissions from soil of the central highlands of Mexico as affected by natural vegetation: a laboratory study, Biol. Fert. Soils, 40, 252-259, 2004.

Potter, C. S., Matson, P. A., Vitousek, P. M., and Davidson, E. A.: Process modeling of controls on nitrogen trace gas emissions from soils worldwide, J. Geophys. Res.-Atmos., 101, 13611377, doi:10.1029/95JD02028, 1996.

30 Prather, M. J. and Hsu, J.: Coupling of nitrous oxide and methane by global atmospheric chemistry, Science, 330, 952-954, doi:10.1126/science.1196285, 2010.
BGD

10, 19811-19865, 2013

Global

land-atmosphere

exchange of methane

and nitrous oxide

H. Tian et al.

Title Page

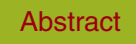

Introduction

Conclusions

Tables

References

Figures

14

4

Back

Close

Full Screen / Esc

Printer-friendly Version

Interactive Discussion 
Prinn, R., Cunnold, D., Rasmussen, R., Simmonds, P., Alyea, F., Crawford, A., Fraser, P., and Rosen, R.: Atmospheric emissions and trends of nitrous oxide deduced from 10 years of ALE-GAGE data, J. Geophys. Res.-Atmos., 95(11), 18369-18385, 1990.

Raghoebarsing, A. A., Pol, A., van de Pas-Schoonen, K. T., Smolders, A. J. P., Ettwig, K. F., $5 \quad$ Rijpstra, W. I. C., Schouten, S., Damsté, J. S. S., Op den Camp, H. J. M., Jetten, M. S. M., and Strous, M.: A microbial consortium couples anaerobic methane oxidation to denitrification, Nature, 440, 918-921, 2006.

Reay, D. S., Davidson, E. A., Smith, K. A., Smith, P., Melillo, J. M., Dentener, F., and Crutzen, P. J.: Global agriculture and nitrous oxide emissions, Nat. Clim. Change, 2, 410416, 2012.

Regina, K., Syväsalo, E., Hannukkala, A., and Esala, M.: Fluxes of $\mathrm{N}_{2} \mathrm{O}$ from farmed peat soils in Finland, Eur. J. Soil Sci., 55, 591-599, 2004.

Ren, W., Tian, H., Liu, M., Zhang, C., Chen, G., Pan, S., Felzer, B., and Xu, X.: Effects of tropospheric ozone pollution on net primary productivity and carbon storage in terrestrial ecosystems of China, J. Geophys. Res.-Atmos., 112, D22S09, doi:10.1029/2007JD008521, 2007.

Ren, W., Tian, H., Xu, X., Liu, M., Lu, C., Chen, G., Melillo, J., Reilly, J., and Liu, J.: Spatial and temporal patterns of $\mathrm{CO}_{2}$ and $\mathrm{CH}_{4}$ fluxes in China's croplands in response to multifactor environmental changes, Tellus B, 63, 222-240, 2011.

20 Ridgwell, A. J., Marshall, S. J., and Gregson, K.: Consumption of atmospheric methane by soils: a process-based model, Global Biogeochem. Cy., 13, 59-70, doi:10.1029/1998GB900004, 1999.

Ringeval, B., de Noblet-Ducoudré, N., Ciais, P., Bousquet, P., Prigent, C., Papa, F., and Rossow, W. B.: An attempt to quantify the impact of changes in wetland extent on methane emissions on the seasonal and interannual time scales, Global Biogeochem. Cy., 24, GB2003, doi:10.1029/2008GB003354, 2010.

Ruser, R., Flessa, H., Schilling, R., Beese, F., and Munch, J. C.: Effect of crop-specific field management and $\mathrm{N}$ fertilization on $\mathrm{N}_{2} \mathrm{O}$ emissions from a fine-loamy soil, Nutr. Cycl. Agroecosys., 59, 177-191, doi:10.1023/A:1017512205888, 2001.

30 Saikawa, E., Prinn, R. G., Dlugokencky, E., Ishijima, K., Dutton, G. S., Hall, B. D., Langenfelds, R., Tohjima, Y., Machida, T., Manizza, M., Rigby, M., O’Doherty, S., Patra, P. K., Harth, C. M., Weiss, R. F., Krummel, P. B., van der Schoot, M., Fraser, P. B., Steele, L. P.,
BGD

10, 19811-19865, 2013

Global

land-atmosphere

exchange of methane

and nitrous oxide

H. Tian et al.

Title Page

Abstract

Introduction

Conclusions

Tables

References

Figures

14

4

Back

Close

Full Screen / Esc

Printer-friendly Version

Interactive Discussion 
Aoki, S., Nakazawa, T., and Elkins, J. W.: Global and regional emissions estimates for $\mathrm{N}_{2} \mathrm{O}$, Atmos. Chem. Phys. Discuss., 13, 19471-19525, doi:10.5194/acpd-13-19471-2013, 2013.

Saikawa, E., Schlosser, C. A., and Prinn, R. G.: Global modeling of soil nitrous oxide emissions from natural processes, Global Biogeochem. Cy., 27, 972-989, doi:10.1002/gbc.20087, 52013

Schulze, E. D., Luyssaert, S., Ciais, P., Freibauer, A., Al, I. A. J. et, Soussana, J. F., Smith, P., Grace, J., Levin, I., Thiruchittampalam, B., Heimann, M., Dolman, A. J., Valentini, R., Bousquet, P., Peylin, P., Peters, W., Rödenbeck, C., Etiope, G., Vuichard, N., Wattenbach, M., Nabuurs, G. J., Poussi, Z., Nieschulze, J., and Gash, J. H.: Importance of methane and nitrous oxide for Europe's terrestrial greenhouse-gas balance, Nat. Geosci., 2, 842-850, 2009.

Song, C., Xu, X., Tian, H., and Wang, Y.: Ecosystem-atmosphere exchange of $\mathrm{CH}_{4}$ and $\mathrm{N}_{2} \mathrm{O}$ and ecosystem respiration in wetlands in the Sanjiang Plain, northeastern China, Glob. Change Biol., 15, 692-705, 2009.

Spahni, R., Wania, R., Neef, L., van Weele, M., Pison, I., Bousquet, P., Frankenberg, C., Fos15 ter, P. N., Joos, F., Prentice, I. C., and van Velthoven, P.: Constraining global methane emissions and uptake by ecosystems, Biogeosciences, 8, 1643-1665, doi:10.5194/bg-8-16432011, 2011.

Steudler, P. A., Bowden, R. D., Melillo, J. M., and Aber, J. D.: Influence of nitrogen fertilization on methane uptake in temperate forest soils, Nature, 341, 314-316, 1989.

Strack, M., Kellner, E., and Waddington, J. M.: Dynamics of biogenic gas bubbles in peat and their effects on peatland biogeochemistry, Global Biogeochem. Cy., 19, GB1003, doi:10.1029/2004GB002330, 2005.

Svensson, B. H. and Rosswall, T.: In situ methane production from acid peat in plant communities with different moisture regimes in a subarctic mire, Oikos, 43, 341, doi:10.2307/3544151, 251984.

Tian, H., Xu, X., Liu, M., Ren, W., Zhang, C., Chen, G., and Lu, C.: Spatial and temporal patterns of $\mathrm{CH}_{4}$ and $\mathrm{N}_{2} \mathrm{O}$ fluxes in terrestrial ecosystems of North America during 1979-2008: application of a global biogeochemistry model, Biogeosciences, 7, 2673-2694, doi:10.5194/bg7-2673-2010, 2010.

so Tian, H., Melillo, J. M., Lu, C., Kicklighter, D. W., Liu, M., Ren, W., Xu, X., Chen, G., Zhang, C., Pan, S., Liu, J., and Running, S.: China's terrestrial carbon balance: contributions from multiple global change factors, Global Biogeochem. Cy., 25, GB1007, doi:10.1029/2010GB003838, 2011a.
BGD

10, 19811-19865, 2013

Global

land-atmosphere

exchange of methane

and nitrous oxide

H. Tian et al.

Title Page

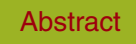

Introduction

Conclusions

Tables

References

Figures

14

4

Back

Close

Full Screen / Esc

Printer-friendly Version

Interactive Discussion 
Tian, H., Xu, X., Lu, C., Liu, M., Ren, W., Chen, G., Melillo, J., and Liu, J.: Net exchanges of $\mathrm{CO}_{2}, \mathrm{CH}_{4}$, and $\mathrm{N}_{2} \mathrm{O}$ between China's terrestrial ecosystems and the atmosphere and their contributions to global climate warming, J. Geophys. Res.-Biogeo., 116, G02011, doi:10.1029/2010JG001393, 2011b.

5 Tian, H., Lu, C., Chen, G., Tao, B., Pan, S., Del Grosso, S., Xu, X., Bruhwiler, L., Wofsy, S. C., Kort, E. A., and Prior, S. A.: Contemporary and projected biogenic fluxes of methane and nitrous oxide in North American terrestrial ecosystems, Front. Ecol. Environ., 10, 528-536, doi:10.1890/120057, 2012a.

Tian, H., Chen, G., Zhang, C., Liu, M., Sun, G., Chappelka, A., Ren, W., Xu, X., Lu, C., Pan, S., Chen, H., Hui, D., McNulty, S., Lockaby, G., and Vance, E.: Century-scale response of ecosystem carbon storage to multifactorial global change in the southern United States, Ecosystems, 15, 674-694, 2012b.

Tian, H., Lu, C., Melillo, J., Ren, W., Huang, Y., Xu, X., Liu, M., Zhang, C., Chen, G., Pan, S., Liu, J., and Reilly, J.: Food benefit and climate warming potential of nitrogen fertilizer uses in China, Environ. Res. Lett., 7, 044020, doi:10.1088/1748-9326/7/4/044020, 2012c.

Toet, S., Ineson, P., Peacock, S., and Ashmore, M.: Elevated ozone reduces methane emissions from peatland mesocosms, Glob. Change Biol., 17, 288-296, 2011.

Towprayoon, S., Smakgahn, K., and Poonkaew, S.: Mitigation of methane and nitrous oxide emissions from drained irrigated rice fields, Chemosphere, 59, 1547-1556, 2005.

US EPA (Environmental Protection Agency): Global Anthropogenic Non- $\mathrm{CO}_{2}$ Greenhouse Gas Emissions: 1990-2020, available at: http://www.epa.gov/nonco2/econ-inv/international.html, 2006.

US EPA (US Environmental Protection Agency): Inventory of US Greenhouse-Gas Emissions and Sinks: 1990-2009, EPA 430-R-12-001, US Environmental Protection Agency, Washington, DC, 2011.

US EPA (US Environmental Protection Agency): Methane and Nitrous Oxide Emissions from Natural Sources, US Environmental Protection Agency, Washington, DC, USA, available at: http://www.epa.gov/outreach/pdfs/ Methane-and-Nitrous-Oxide-Emissions-From-Natural-Sources.pdf, 2010.

30 US EPA: Global Anthropogenic Non- $\mathrm{CO}_{2}$ Greenhouse Gas Emissions: 1990-2020, US Environmental Protection Agency, available at: http://www.epa.gov/nonco2/econ-inv/ international.html, 2006.
BGD

10, 19811-19865, 2013

Global

land-atmosphere

exchange of methane

and nitrous oxide

H. Tian et al.

Title Page

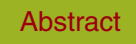

Introduction

Conclusions

Tables

References

Figures

14

4

Back

Close

Full Screen / Esc

Printer-friendly Version

Interactive Discussion 
Ussiri, D. and Lal, R.: Soil Emission of Nitrous Oxide and its Mitigation, New York, 243-275, 2012.

Van Aardenne, J. A., Dentener, F. J., Olivier, J. G. J., Goldewijk, C. G. M. K., and Lelieveld, J.: A $1^{\circ} \times 1^{\circ}$ resolution data set of historical anthropogenic trace gas emissions for the period 1890-1990, Global Biogeochem. Cy., 15, 909-928, 2001.

Veldkamp, E. and Keller, M.: Nitrogen oxide emissions from a banana plantation in the humid tropics, J. Geophys. Res.-Atmos., 102, 15889-15898, 1997.

Vitt, D., Bayley, S., Jin, T., Halsey, L., Parker, B., and Craik, R.: Methane and carbon dioxide production from wetlands in boreal Alberta, Report on Contract No. 90-0270 to Alberta

10 Environment, 35 pp., 1990

Walter, B. P. and Heimann, M.: A process-based, climate-sensitive model to derive methane emissions from natural wetlands: application to five wetland sites, sensitivity to model parameters, and climate, Global Biogeochem. Cy., 14, 745-765, 2000.

Wania, R., Melton, J. R., Hodson, E. L., Poulter, B., Ringeval, B., Spahni, R., Bohn, T., 15 Avis, C. A., Chen, G., Eliseev, A. V., Hopcroft, P. O., Riley, W. J., Subin, Z. M., Tian, H., van Bodegom, P. M., Kleinen, T., Yu, Z. C., Singarayer, J. S., Zürcher, S., Lettenmaier, D. P., Beerling, D. J., Denisov, S. N., Prigent, C., Papa, F., and Kaplan, J. O.: Present state of global wetland extent and wetland methane modelling: methodology of a model inter-comparison project (WETCHIMP), Geosci. Model Dev., 6, 617-641, doi:10.5194/gmd-6-617-2013, 2013.

Wei, Y., Liu, S., Huntzinger, D. N., Michalak, A. M., Viovy, N., Post, W. M., Schwalm, C. R., Schaefer, K., Jacobson, A. R., Lu, C., Tian, H., Ricciuto, D. M., Cook, R. B., Mao, J., and Shi, X.: The North American Carbon Program Multi-scale Synthesis and Terrestrial Model Intercomparison Project - Part 2: Environmental driver data, Geosci. Model Dev. Discuss., 6, 5375-5422, doi:10.5194/gmdd-6-5375-2013, 2013.

Weitz, A. M., Veldkamp, E., Keller, M., Neff, J., and Crill, P. M.: Nitrous oxide, nitric oxide, and methane fluxes from soils following clearing and burning of tropical secondary forest, J. Geophys. Res.-Atmos., 103, 28047-28058, 1998.

Weitz, A., Linder, E., Frolking, S., Crill, P., and Keller, $\mathrm{M} .: \mathrm{N}_{2} \mathrm{O}$ emissions from humid tropical agricultural soils: effects of soil moisture, texture and nitrogen availability, Soil Biol. Biochem., $30 \quad 33,1077-1093,2001$.

Whalen, S. C. and Reeburgh, W. S.: A methane flux time series for tundra environments, Global Biogeochem. Cy., 2, 399-409, 1988.
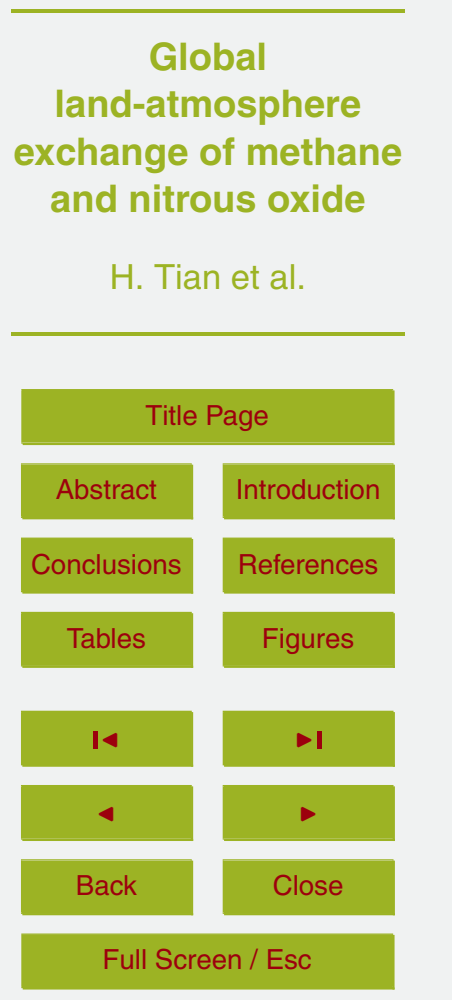

Printer-friendly Version

Interactive Discussion 
$\mathrm{Xu}, \mathrm{X}$. and Tian, $\mathrm{H} .:$ Methane exchange between marshland and the atmosphere over China during 1949-2008, Global Biogeochem. Cy., 26, GB2006, doi:10.1029/2010GB003946, 2012.

$\mathrm{Xu}, \mathrm{X}$., Tian, $\mathrm{H}$., and Hui, D.: Convergence in the relationship of $\mathrm{CO}_{2}$ and $\mathrm{N}_{2} \mathrm{O}$ exchanges 5 between soil and atmosphere within terrestrial ecosystems, Glob. Change Biol., 14, 1651$1660,2008$.

Xu, X. F., Tian, H. Q., Zhang, C., Liu, M. L., Ren, W., Chen, G. S., Lu, C. Q., and Bruhwiler, L.: Attribution of spatial and temporal variations in terrestrial methane flux over North America, Biogeosciences, 7, 3637-3655, doi:10.5194/bg-7-3637-2010, 2010.

10 Xu, X. F., Tian, H. Q., Chen, G. S., Liu, M. L., Ren, W., Lu, C. Q., and Zhang, C.: Multifactor controls on terrestrial $\mathrm{N}_{2} \mathrm{O}$ flux over North America from 1979 through 2010, Biogeosciences, 9, 1351-1366, doi:10.5194/bg-9-1351-2012, 2012.

Yan, X., Akiyama, H., Yagi, K., and Akimoto, H.: Global estimations of the inventory and mitigation potential of methane emissions from rice cultivation conducted using the 2006 Intergovernmental Panel on Climate Change Guidelines, Global Biogeochem. Cy., 23, GB2002, doi:10.1029/2008GB003299, 2009.

Yu, K., Faulkner, S. P., and Baldwin, M. J.: Effect of hydrological conditions on nitrous oxide, methane, and carbon dioxide dynamics in a bottomland hardwood forest and its implication for soil carbon sequestration, Glob. Change Biol., 14, 798-812, 2008.

20 Zhang, C., Tian, H., Chappelka, A. H., Ren, W., Chen, H., Pan, S., Liu, M., Styers, D. M., Chen, G., and Wang, Y.: Impacts of climatic and atmospheric changes on carbon dynamics in the Great Smoky Mountains National Park, Environ. Pollut., 149, 336-347, 2007.

Zhang, F., Qi, J., Li, F. M., Li, C. S., and Li, C. B.: Quantifying nitrous oxide emissions from Chinese grasslands with a process-based model, Biogeosciences, 7, 2039-2050, doi:10.5194/bg-7-2039-2010, 2010.

Zhuang, Q., Lu, Y., and Chen, M.: An inventory of global $\mathrm{N}_{2} \mathrm{O}$ emissions from the soils of natural terrestrial ecosystems, Atmos. Environ., 47, 66-75, 2012.

Zhuang, Q., Melillo, J. M., Kicklighter, D. W., Prinn, R. G., McGuire, A. D., Steudler, P. A., Felzer, B. S., and Hu, S.: Methane fluxes between terrestrial ecosystems and the atmosphere at northern high latitudes during the past century: a retrospective analysis with a process-based biogeochemistry model, Global Biogeochem. Cy., 18, GB3010, doi:10.1029/2004GB002239, 2004.

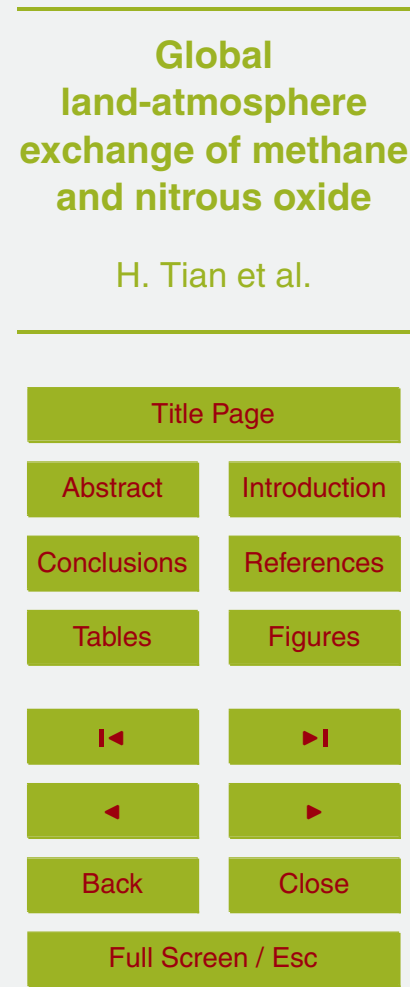

Printer-friendly Version

Interactive Discussion 
Table 1. DLEM validation against site-level measurement of $\mathrm{CH}_{4}$ and $\mathrm{N}_{2} \mathrm{O}$ fluxes.

\begin{tabular}{|c|c|c|c|c|}
\hline Location & Land cover type & DLEM & Observation & Reference \\
\hline \multicolumn{5}{|c|}{$\mathrm{CH}_{4}$ fluxes $\left(\mathrm{gCm}^{-2} \mathrm{yr}^{-1}\right)$} \\
\hline $19^{\circ} \mathrm{E}, 68^{\circ} \mathrm{N}$ & Mire & 6.1737 & $0.13-30.5$ & Svensson et al. (1984) \\
\hline $147.85^{\circ} \mathrm{W}, 64.8667^{\circ} \mathrm{N}$ & Tundra & 7.2921 & $0.47-8.05$ & Whalen et al. (1988) \\
\hline $47^{\circ} 32^{\prime} \mathrm{N}, 93^{\circ} 28^{\prime} \mathrm{W}$ & Peatland & 19.15 & $3.5-65.7$ & Dise et al. (1993) \\
\hline $113^{\circ} \mathrm{W}, 55^{\circ} \mathrm{N}$ & Sedge meadow & 18.92 & 21.7 & Vitt et al. (1990) \\
\hline $66^{\circ} \mathrm{W}, 54^{\circ} \mathrm{N}$ & Fen & 9.34 & $1.3-9.8$ & Moore et al. (1990) \\
\hline $4^{\circ} \mathrm{W}, 55^{\circ} \mathrm{N}$ & Bog & 9.29 & $1.3-9.3$ & Clymo et al. (1971) \\
\hline $21^{\circ} \mathrm{W}, 74.5^{\circ} \mathrm{N}$ & Bog & 7.44 & $0-66.96$ & Christensen et al. (2000) \\
\hline $2.90^{\circ} \mathrm{S}, 54.95^{\circ} \mathrm{W}$ & Forest & -0.17 & -0.12 to -0.37 & Davidson et al. (2008) \\
\hline $105^{\circ} \mathrm{W}, 53^{\circ} \mathrm{N}$ & Forest & -0.041 & -0.063 & Hatson et al. (2009) \\
\hline $5^{\circ} \mathrm{E}, 52^{\circ} \mathrm{N}$ & Peatland & 28.23 & $14.5-68.9$ & Hendriks et al. (2007) \\
\hline $133^{\circ} 31^{\prime} \mathrm{E}, 47^{\circ} 35^{\prime} \mathrm{N}$ & Freshwater marsh & $14.5 \pm 3.0^{a}$ & $11.8 \pm 2.6^{a}$ & Lu et al. (2012) \\
\hline $112^{\circ} 11^{\prime} \mathrm{E}, 23^{\circ} 11^{\prime} \mathrm{N}$ & Tropical forest & $-0.115^{\mathrm{a}}$ & $-0.145 \pm 0.02^{a}$ & Lu et al. (2012) \\
\hline $90.11^{\circ} \mathrm{W}, 29.8^{\circ} \mathrm{N}$ & Woody wetland & 21.18 & $-2.63-24.9$ & Yu et al. (2008) \\
\hline $84.67^{\circ} \mathrm{W}, 45.57^{\circ} \mathrm{N}$ & Trembling aspen & $-0.1 \pm 0.07$ & 0.271 & Ambus et al. (1999) \\
\hline $122.23^{\circ} \mathrm{W}, 37.4^{\circ} \mathrm{N}$ & Grassland & $\begin{array}{l}-0.30 \pm 0.01 \text { to } \\
-0.38 \pm 0.05^{b}\end{array}$ & $\begin{array}{l}-0.13 \pm 0.01 \text { to } \\
-0.45 \pm 0.14^{b}\end{array}$ & Blankinship et al. (2010) \\
\hline $95.167^{\circ} \mathrm{W}, 47.25^{\circ} \mathrm{N}$ & Rice & $342.18 \pm 38.05$ & 369.75 & Harriss et al. (1985) \\
\hline $118^{\circ} \mathrm{E}, 32^{\circ} \mathrm{N}$ & Rice paddies & 22.99 & $18.14 \pm 21.17$ & Xiong et al. (2007) \\
\hline $91.55^{\circ} \mathrm{W}, 29.87^{\circ} \mathrm{N}$ & Wetland & $52-57$ & $4.3-160$ & DeLaune et al. (1983) \\
\hline \multicolumn{5}{|c|}{$\mathrm{N}_{2} \mathrm{O}$ fluxes $\left(\mathrm{gNm}^{-2} \mathrm{yr}^{-1}\right)$} \\
\hline $63^{\circ} \mathrm{W}, 10^{\circ} \mathrm{S}$ & Forest & 0.1 & $0.05-0.322$ & Garcia (2003) \\
\hline $94^{\circ} \mathrm{W}, 3^{\circ} \mathrm{S}$ & Forest & 0.13 & $0.08-0.22$ & Matson (1987) \\
\hline $48^{\circ} \mathrm{E}, 1^{\circ} \mathrm{N}$ & Agriculture & 0.17 & $0.08-0.21$ & Dambreville (2008) \\
\hline $79^{\circ} \mathrm{E}, 9^{\circ} \mathrm{N}$ & Forest & 0.17 & $0.09-0.73$ & Koehler (2009) \\
\hline $84^{\circ} \mathrm{W}, 10^{\circ} \mathrm{N}$ & Forest & 0.17 & $0.08-0.58$ & Keller (1994) \\
\hline $76^{\circ} \mathrm{W}, 10^{\circ} \mathrm{N}$ & Forest & 0.16 & $0.15-0.54$ & Matson (1987) \\
\hline $84^{\circ} \mathrm{W}, 10^{\circ} \mathrm{N}$ & Agriculture & 0.38 & $0.029-0.75$ & $\begin{array}{l}\text { Veldkamp }(1997) ; \\
\text { Weitz }(1998,2001)\end{array}$ \\
\hline $65^{\circ} \mathrm{W}, 17^{\circ} \mathrm{N}$ & Fallow & 0.22 & $0.007-1.92$ & Ericson (2001) \\
\hline $65^{\circ} \mathrm{W}, 18^{\circ} \mathrm{N}$ & Forest & 0.22 & $0.002-0.077$ & Erickson (2002) \\
\hline $98^{\circ} \mathrm{W}, 19^{\circ} \mathrm{N}$ & Agriculture & 0.262 & $0.14-0.29$ & Luqueno (2009) \\
\hline $83^{\circ} \mathrm{W}, 19^{\circ} \mathrm{N}$ & Forest & 0.03 & $0-0.022$ & Matson (1987) \\
\hline $105.03^{\circ} \mathrm{W}, 19.3^{\circ} \mathrm{N}$ & Forest & 0.06 & $0.009-0.048$ & Davidson (1993) \\
\hline $100^{\circ} \mathrm{W}, 21^{\circ} \mathrm{N}$ & Agriculture & 0.1 & $0.08-0.19$ & Perez (2004) \\
\hline
\end{tabular}

\section{Global \\ land-atmosphere \\ exchange of methane and nitrous oxide \\ H. Tian et al.}

\section{Title Page}

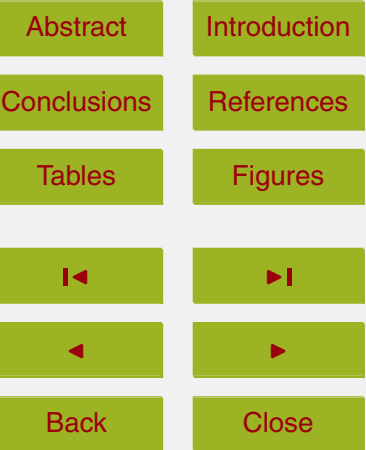

Full Screen / Esc

Printer-friendly Version

Interactive Discussion 
Table 1. Continued.

\begin{tabular}{|c|c|c|c|c|}
\hline Location & Land cover type & DLEM & Observation & Reference \\
\hline $157^{\circ} \mathrm{W}, 21^{\circ} \mathrm{N}$ & Forest & 0.04 & $0.002-0.007$ & Vitousek (1989) \\
\hline $91^{\circ} \mathrm{W}, 35^{\circ} \mathrm{N}$ & Agriculture & 0.07 & $0.01-0.05$ & Cochran (1997) \\
\hline $104^{\circ} \mathrm{W}, 38.5^{\circ} \mathrm{N}$ & Agriculture & 0.24 & $0.082-0.25$ & $\begin{array}{l}\text { Bronson (1992); Delago } \\
\text { (1996); Mosier (1986) }\end{array}$ \\
\hline $107^{\circ} \mathrm{W}, 39^{\circ} \mathrm{N}$ & Agriculture & 0.02 & 0.198 & $\begin{array}{l}\text { Mosier and Hutchinson } \\
\text { (1981) }\end{array}$ \\
\hline $104^{\circ} \mathrm{W}, 40^{\circ} \mathrm{N}$ & Agriculture & 0.03 & $0.026-0.27$ & Mosier (1982) \\
\hline $102^{\circ} \mathrm{W}, 41^{\circ} \mathrm{N}$ & Agriculture & 0.022 & $0.009-0.011$ & Kessavalou (1998) \\
\hline $72.5^{\circ} \mathrm{W}, 41.5^{\circ} \mathrm{N}$ & Forest & 0.02 & $0.001-0.002$ & Bowden (1990) \\
\hline $72.5^{\circ} \mathrm{W}, 43.5^{\circ} \mathrm{N}$ & Forest & 0.05 & $0.003-0.006$ & Castro (1993) \\
\hline $89.5^{\circ} \mathrm{W}, 43.5^{\circ} \mathrm{N}$ & Forest & 0.08 & $0.019-0.21$ & Goodroad (1984) \\
\hline $71.5^{\circ} \mathrm{W}, 44^{\circ} \mathrm{N}$ & Deciduous & 0.04 & 0.091 & Keller (1983) \\
\hline $68.5^{\circ} \mathrm{W}, 44.5^{\circ} \mathrm{N}$ & Forest & 0.03 & 0.001 & Castro (1993) \\
\hline $11^{\circ} \mathrm{E}, 48^{\circ} \mathrm{N}$ & Agriculture & 0.11 & $0.13-0.96$ & $\begin{array}{l}\text { Flessa (1995); } \\
\text { Ruser et al. (2001) }\end{array}$ \\
\hline $112^{\circ} \mathrm{W}, 49^{\circ} \mathrm{N}$ & Agriculture & 0.02 & $0.025-0.157$ & $\begin{array}{l}\text { Chang (1998); } \\
\text { Hao (2001) }\end{array}$ \\
\hline $14^{\circ} \mathrm{E}, 51^{\circ} \mathrm{N}$ & Forest & 0.06 & $0.004-0.12$ & Butterbach (1997) \\
\hline $106^{\circ} \mathrm{W}, 52^{\circ} \mathrm{N}$ & Agriculture & 0.007 & 0.007 & Corre (1999) \\
\hline $114^{\circ} \mathrm{W}, 53^{\circ} \mathrm{N}$ & Agriculture & 0.026 & $0.011-0.071$ & Lemke (1998) \\
\hline $24^{\circ} \mathrm{E}, 60^{\circ} \mathrm{N}$ & Agriculture & 0.03 & 0.03 & Parela (2006) \\
\hline $26^{\circ} \mathrm{E}, 66^{\circ} \mathrm{N}$ & Agriculture & 0.06 & $0.62-0.73$ & Regina (2004) \\
\hline $13^{\circ} \mathrm{E}, 100^{\circ} \mathrm{N}$ & Agriculture & 0.26 & $0.033-0.051$ & Towprayoon (2005) \\
\hline $28.55^{\circ} \mathrm{E}, 111.3^{\circ} \mathrm{N}$ & Agriculture & 0.6 & $0-0.21$ & Shang (2011) \\
\hline $1^{\circ} \mathrm{E}, 114^{\circ} \mathrm{N}$ & Agriculture & 0.17 & $-5.03-2.9$ & Hadi (2010) \\
\hline $31^{\circ} \mathrm{E}, 118^{\circ} \mathrm{N}$ & Agriculture & 0.03 & $0.003-0.18$ & $\begin{array}{l}\text { Liu (2010); Wang (2011); } \\
\text { Zou (2005) }\end{array}$ \\
\hline $31^{\circ} \mathrm{E}, 120^{\circ} \mathrm{N}$ & Agriculture & 0.43 & $0.18-2.53$ & Hou (2012); Peng (2011) \\
\hline $41^{\circ} \mathrm{E}, 122^{\circ} \mathrm{N}$ & Agriculture & 0.09 & $0.046-0.057$ & Jiao (2005) \\
\hline $31^{\circ} \mathrm{E}, 136^{\circ} \mathrm{N}$ & Agriculture & 0.229 & $0.34-1.2$ & Hadi (2010) \\
\hline
\end{tabular}

a Unit is $\mathrm{g} \mathrm{Cm}^{-2}$ growingseason ${ }^{-1}$

${ }^{\mathrm{b}}$ Unit is $\mathrm{mg} \mathrm{Cm}^{-2}$ day $^{-1}$.

\section{Global \\ land-atmosphere \\ exchange of methane and nitrous oxide \\ H. Tian et al.}

\section{Title Page}

\section{Abstract}

Introduction

Conclusions

References

Tables

Figures

14

4

Back

Close

\section{Full Screen / Esc}

Printer-friendly Version

Interactive Discussion 
Table 2. Annual change rates of multiple environmental factors for different continents from 1981 to 2010.

\begin{tabular}{llllllll}
\hline Environmental factors & Asia & $\begin{array}{l}\text { North } \\
\text { America }\end{array}$ & Europe & Africa & $\begin{array}{l}\text { South } \\
\text { America }\end{array}$ & Oceania & Global \\
\hline Air temperature $\left({ }^{\circ} \mathrm{Cyr}^{-1}\right)$ & $0.035^{\mathrm{b}}$ & $0.030^{\mathrm{b}}$ & $0.039^{\mathrm{b}}$ & $0.032^{\mathrm{b}}$ & $0.016^{\mathrm{b}}$ & 0.0079 & $0.026^{\mathrm{b}}$ \\
Precipitation $\left(\mathrm{mm} \mathrm{mr}^{-1}\right)$ & 0.78 & 0.51 & 0.56 & $2.26^{\mathrm{b}}$ & $3.50^{\mathrm{b}}$ & 2.01 & $0.97^{\mathrm{a}}$ \\
Shortwave radiation $\left(\mathrm{Wm}^{2} \mathrm{yr}^{-1}\right)$ & 0.002 & -0.017 & 0.002 & 0.014 & $0.11^{\mathrm{b}}$ & $0.15^{\mathrm{a}}$ & $0.048^{\mathrm{b}}$ \\
$\mathrm{N}$ deposition $\left(\mathrm{mg} \mathrm{N} \mathrm{m}^{2} \mathrm{yr}^{-1}\right)$ & $8.70^{\mathrm{b}}$ & $2.20^{\mathrm{b}}$ & $4.70^{\mathrm{b}}$ & $5.20^{\mathrm{b}}$ & $7.20^{\mathrm{b}}$ & $0.50^{\mathrm{b}}$ & $5.60^{\mathrm{b}}$ \\
$\mathrm{N}$ fertilizer use $\left(\mathrm{g} \mathrm{N} \mathrm{m}^{2} \mathrm{yr}^{-1}\right)$ & $0.27^{\mathrm{b}}$ & $0.05^{\mathrm{a}}$ & $-0.13^{\mathrm{a}}$ & $0.01^{\mathrm{a}}$ & $0.11^{\mathrm{b}}$ & $0.13^{\mathrm{b}}$ & $0.093^{\mathrm{b}}$ \\
Ozone $\left(\mathrm{ppb}-\mathrm{hrmonth}^{-1}\right)$ & $58.6^{\mathrm{b}}$ & $40.71^{\mathrm{b}}$ & $28.86^{\mathrm{b}}$ & $47.11^{\mathrm{b}}$ & $7.97^{\mathrm{b}}$ & $0.05^{\mathrm{a}}$ & $32.87^{\mathrm{b}}$ \\
Cropland $\left(10^{4} \mathrm{~km}^{2} \mathrm{yr}^{-1}\right)$ & $2.52^{\mathrm{b}}$ & $-0.091^{\mathrm{b}}$ & $-1.45^{\mathrm{b}}$ & $1.96^{\mathrm{b}}$ & $0.72^{\mathrm{b}}$ & $0.17^{\mathrm{b}}$ & $4.01^{\mathrm{b}}$ \\
\hline
\end{tabular}

Note: ${ }^{\mathrm{a}}$ indicates significant change trend at $P<0.05$ and ${ }^{\mathrm{b}}$ indicates significant trend at $P<0.01$.

\section{Global}

land-atmosphere

exchange of methane and nitrous oxide

H. Tian et al.

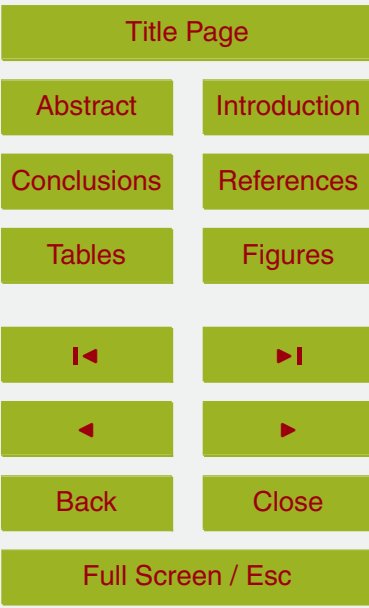

Printer-friendly Version

Interactive Discussion 
Table 3. Annual change rates of multiple environmental factors for different climate zones from 1981 to 2010.

\begin{tabular}{llllll}
\hline Environmental factors & $\begin{array}{l}\text { Northern } \\
\text { polar }\end{array}$ & $\begin{array}{l}\text { Northern } \\
\text { temperate }\end{array}$ & $\begin{array}{l}\text { Northern } \\
\text { tropics }\end{array}$ & $\begin{array}{l}\text { Southern } \\
\text { tropics }\end{array}$ & $\begin{array}{l}\text { Southern } \\
\text { temperate }\end{array}$ \\
\hline Air temperature $\left({ }^{\circ} \mathrm{Cyr}^{-1}\right)$ & $0.039^{\mathrm{b}}$ & $0.034^{\mathrm{b}}$ & $0.033^{\mathrm{b}}$ & $0.016^{\mathrm{b}}$ & 0.007 \\
Precipitation $\left(\mathrm{mm} \mathrm{yr}^{-1}\right)$ & $0.42^{\mathrm{a}}$ & 0.066 & $2.68^{\mathrm{b}}$ & $3.42^{\mathrm{b}}$ & -0.68 \\
$\mathrm{~N}$ deposition $\left(\mathrm{mg} \mathrm{N} \mathrm{m}^{2} \mathrm{yr}^{-1}\right)$ & $0.26^{\mathrm{b}}$ & $5.07^{\mathrm{b}}$ & $8.57^{\mathrm{b}}$ & $2.75^{\mathrm{b}}$ & $0.72^{\mathrm{b}}$ \\
$\mathrm{N}$ fertilizer use $\left(\mathrm{g} \mathrm{N} \mathrm{m}^{2} \mathrm{yr}^{-1}\right)$ & $-0.082^{\mathrm{b}}$ & $0.068^{\mathrm{b}}$ & $0.10^{\mathrm{b}}$ & $0.040^{\mathrm{b}}$ & $0.02^{\mathrm{b}}$ \\
Ozone $\left(\mathrm{ppb}-\mathrm{hrmonth}^{-1}\right)$ & -1.67 & $32.80^{\mathrm{a}}$ & $50.78^{\mathrm{b}}$ & $3.89^{\mathrm{a}}$ & 0.0008 \\
Cropland $\left(10^{4} \mathrm{~km}^{2} \mathrm{yr}^{-1}\right)$ & $-0.01^{\mathrm{a}}$ & $-0.42^{\mathrm{a}}$ & $2.72^{\mathrm{b}}$ & $0.83^{\mathrm{b}}$ & $0.70^{\mathrm{b}}$ \\
\hline
\end{tabular}

Note: ${ }^{\mathrm{a}}$ indicates significant change trend at $P<0.05$ and ${ }^{\mathrm{b}}$ indicates significant trend at $P<0.01$.

\section{Global}

land-atmosphere

exchange of methane and nitrous oxide

H. Tian et al.

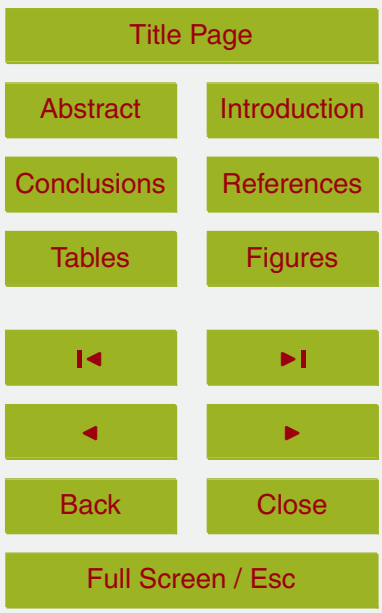

Printer-friendly Version

Interactive Discussion 
Table 4. Average terrestrial $\mathrm{CH}_{4}\left(\mathrm{TgCyr}^{-1} ; 1 \mathrm{Tg}=10^{12} \mathrm{~g}\right)$ and $\mathrm{N}_{2} \mathrm{O}\left(\mathrm{TgNyr}^{-1}\right)$ fluxes and their change rates (\%) for different climate zones during 1981-2010 as simulated by the DLEM.

\begin{tabular}{|c|c|c|c|c|c|c|}
\hline Variables & $\begin{array}{l}\text { Time } \\
\text { period }^{a}\end{array}$ & $\begin{array}{l}\text { Northern } \\
\text { polar } \\
\text { zone }\end{array}$ & $\begin{array}{l}\text { Northern } \\
\text { temperate } \\
\text { zone }\end{array}$ & $\begin{array}{l}\text { Northern } \\
\text { tropical } \\
\text { zone }\end{array}$ & $\begin{array}{l}\text { Southern } \\
\text { tropical } \\
\text { zone }\end{array}$ & $\begin{array}{l}\text { Southern } \\
\text { temperate } \\
\text { zone }\end{array}$ \\
\hline \multirow[t]{4}{*}{$\begin{array}{l}\mathrm{CH}_{4} \\
\text { fluxes }\end{array}$} & 1980s & $9.89 \pm 0.24^{b}$ & $\begin{array}{l}20.62 \pm \\
0.44\end{array}$ & $\begin{array}{l}54.55 \pm \\
0.92\end{array}$ & $\begin{array}{l}77.03 \pm \\
0.92\end{array}$ & $0.16 \pm 0.08$ \\
\hline & 2000s & $\begin{array}{l}10.80 \pm \\
0.26\end{array}$ & $\begin{array}{l}22.98 \pm \\
0.57\end{array}$ & $\begin{array}{l}61.31 \pm \\
1.42\end{array}$ & $\begin{array}{l}81.16 \pm \\
1.12\end{array}$ & $0.23 \pm 0.12$ \\
\hline & Mean & $\begin{array}{l}10.30 \pm \\
0.22\end{array}$ & $\begin{array}{l}21.89 \pm \\
0.51\end{array}$ & $\begin{array}{l}58.15 \pm \\
1.32\end{array}$ & $\begin{array}{l}78.88 \pm \\
0.92\end{array}$ & $0.21 \pm 0.06$ \\
\hline & $\begin{array}{l}\text { Change } \\
\text { rate }(\%)\end{array}$ & 9.22 & 11.44 & 12.39 & 5.37 & 47.53 \\
\hline \multirow{4}{*}{$\begin{array}{l}\mathrm{N}_{2} \mathrm{O} \\
\text { fluxes }\end{array}$} & 1980s & $0.34 \pm 0.01$ & $2.47 \pm 0.05$ & $4.43 \pm 0.19$ & $3.93 \pm 0.15$ & $0.14 \pm 0.01$ \\
\hline & $2000 s$ & $0.38 \pm 0.02$ & $2.88 \pm 0.11$ & $5.96 \pm 0.36$ & $4.68 \pm 0.19$ & $0.17 \pm 0.01$ \\
\hline & Mean & $0.35 \pm 0.01$ & $2.63 \pm 0.08$ & $5.11 \pm 0.28$ & $4.27 \pm 0.15$ & $0.15 \pm 0.01$ \\
\hline & $\begin{array}{l}\text { Change } \\
\text { rate }(\%)\end{array}$ & 14.37 & 16.54 & 34.67 & 19.03 & 23.96 \\
\hline
\end{tabular}

${ }^{a}$ Mean annual fluxes in the period $1981-1990,2001-2010$ and $1981-2010 .{ }^{b}$ The values are denoted as mean \pm 2 SE (standard error).

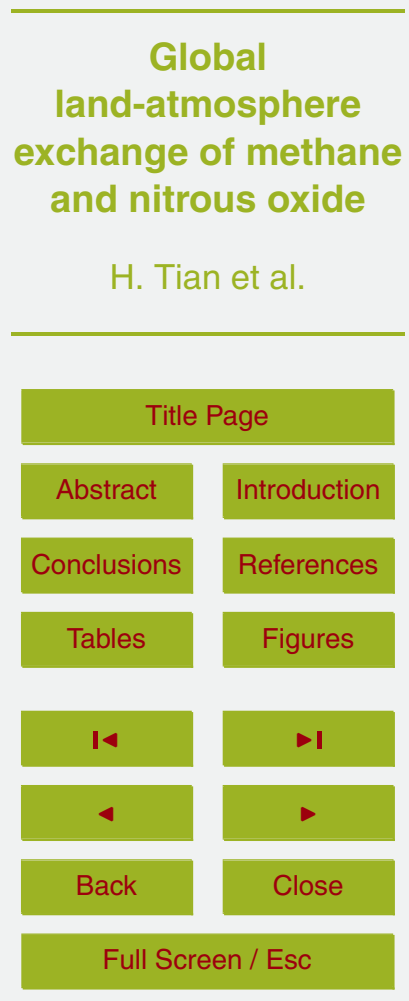

Printer-friendly Version

Interactive Discussion 


\section{Global}

land-atmosphere

exchange of methane and nitrous oxide

H. Tian et al.

Table 5. Average terrestrial $\mathrm{CH}_{4}\left(\mathrm{TgCyr}^{-1}\right)$ and $\mathrm{N}_{2} \mathrm{O}\left(\mathrm{TgNyr}^{-1}\right)$ fluxes for different biome types during 1981-2010 as simulated by the DLEM model.

\begin{tabular}{lccccc}
\hline Variables & Forest & Shrubland & Wetland & Grassland & Cropland \\
\hline $\mathrm{CH}_{4}$ fluxes & $-6.43 \pm 0.11$ & $-4.38 \pm 0.04$ & $130.74 \pm 1.11$ & $-1.90 \pm 0.01$ & $54.37 \pm 1.98$ \\
$\mathrm{~N}_{2} \mathrm{O}$ fluxes & $4.28 \pm 0.10$ & $2.82 \pm 0.11$ & $0.97 \pm 0.03$ & $0.82 \pm 0.03$ & $3.36 \pm 0.28$ \\
\hline
\end{tabular}

Title Page

Abstract

Introduction

Conclusions

References

Tables

Figures

14

$>$ I

4

Back

Close

Full Screen / Esc

Printer-friendly Version

Interactive Discussion 
Table 6. Comparison of global terrestrial $\mathrm{CH}_{4}$ and $\mathrm{N}_{2} \mathrm{O}$ fluxes estimated from multiple sources.

\begin{tabular}{lllll}
\hline $\begin{array}{l}\mathrm{CH}_{4} \text { flux } \\
\left(\mathrm{TgCyr}^{-1}\right)\end{array}$ & Time period & This study & Others & Reference \\
\hline Global & $1990 \mathrm{~s}$ & $163.86-182.51$ & $86-195$ & $\begin{array}{l}\text { Fung et al. (1991); Houweling } \\
\text { et al. (1999) }\end{array}$ \\
\hline $\begin{array}{l}\text { Global } \\
\text { natural } \\
\text { wetland }\end{array}$ & $1993-2004$ & $129.70-135.92$ & $106-198$ & $\begin{array}{l}\text { Melton et al. (2012) } \\
\text { Cao et al. (1998); Bousquet } \\
\text { et al. (2011); Riley et al. (2011) }\end{array}$ \\
& $1990 \mathrm{~s}$ & $126.47-135.92$ & $69.0-202.5$ & $\begin{array}{l}\text { Liu (1996) } \\
\text { US EPA (2011) }\end{array}$ \\
\hline $\begin{array}{l}\text { Global } \\
\text { upland }\end{array}$ & $1990 \mathrm{~s}$ & $126.47-135.92$ & 127 & $78.75-208.50$ \\
\hline $\begin{array}{l}\text { Rice paddy } \\
\text { land }\end{array}$ & $190.90-137.67$ & -17.76 to-16.13 & -19.5 to -25.0 & $\begin{array}{l}\text { Ito and Inatomi (2012); Potter } \\
\text { et al. (1996); Ridgwell et al. (1999); } \\
\text { Del Grosso et al. (2000) }\end{array}$ \\
\hline $\begin{array}{l}\text { High-latitude } \\
\text { wetland } \\
\left(>60^{\circ} \mathrm{N}\right)\end{array}$ & $1990 \mathrm{~s}$ & $51.42-62.40$ & $19.2-84.0$ & $\begin{array}{l}\text { Cao et al. (1998); Chen and Prinn } \\
\text { (2005); Patra et al. (2009); Ito and } \\
\text { Inatomi (2012); Yan et al. (2009) }\end{array}$ \\
\hline $\begin{array}{l}\text { High-latitude } \\
\left(>60^{\circ} \mathrm{N}\right)\end{array}$ & $1990 \mathrm{~s}$ & $8.89-10.89$ & 15.75 & Christensen et al. (1996) \\
\hline
\end{tabular}
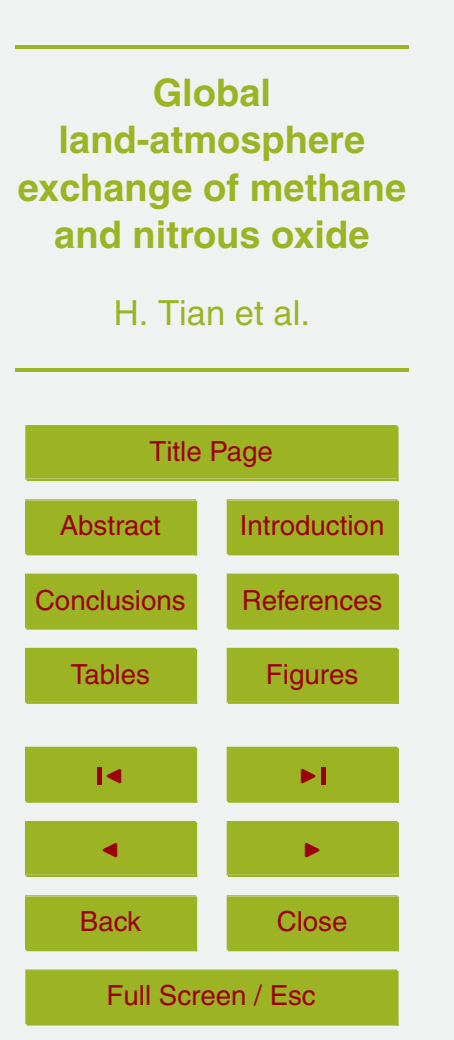

Printer-friendly Version

Interactive Discussion 
Table 6. Continued.

\begin{tabular}{lllll}
\hline $\begin{array}{l}\mathrm{N}_{2} \mathrm{O} \text { flux } \\
\left(\mathrm{TgCyr}^{-1}\right)\end{array}$ & Time period & This study & Other & Reference \\
\hline Global & $1980-2000$ & $10.49-14.30$ & $13.31(8.19-18.43)$ & Xu et al. (2008) \\
& $1990-1994$ & $11.51-12.15$ & 11.33 & Liu, 1996 \\
& $1990-1994$ & $11.51-12.15$ & 9.5 & Nevison et al. (1996) \\
& $1997-2001$ & $12.62-14.30$ & $12.55^{\mathrm{a}}$ & Huang et al. (2008) \\
& $1998-2001$ & $12.62-14.30$ & $10.7-12.7$ & Hirsch et al. (2006) \\
& $1990 \mathrm{~s}$ & $11.51-14.30$ & $3-39$ & Mosier et al. (1998); Banin (1986); \\
& & & & Kroeze et al. (1999); Seiler and \\
& & & & Conrad (1987) \\
\hline Global natural & 2000 & 8.67 & $1.96-4.56^{\mathrm{b}}$ & Zhuang et al. (2012) \\
land & 1990 & 8.76 & $6.6(3.3-9.0)^{\mathrm{c}}$ & FAO/IFA 2001; US EPA 2010 \\
& Early 1980s & $7.97-8.48$ & $7-16$ & Bowden (1986) \\
& $1995-2008$ & $8.67-10.02$ & $5.27-8.28$ & Saikawa et al. (2013) \\
\hline Global & 1990 & 3.00 & $2.9^{\mathrm{d}}$ & FAO/IFA 2001 \\
cropland & 1995 & 3.29 & 2.8 & Bouwman et al. (2002) \\
& 2000 & 3.50 & $4.4^{\mathrm{e}}$ & US EPA 2011 \\
& 2000 & 3.50 & $2.6-3.5^{\dagger}$ & Davison (2009) \\
& $1995-2008$ & $2.86-4.39$ & $2.65-3.96$ & Saikawa et al. (2013) \\
\hline Global & $2000-2007$ & 0.85 & 0.92 & Zhang et al. (2010) \\
grassland & 2000 & 0.78 & 1.31 & Zhuang et al. (2012) \\
& $2000-2008$ & 0.85 & 1.52 & Xu et al. (2008) \\
\hline Global & $2000-2008$ & 4.44 & 6.99 & Xu et al. (2008) \\
forest & 2000 & 4.18 & 1.30 & Zhuang et al. (2012) \\
\hline
\end{tabular}

a The emission from ocean (23\%) is excluded.

${ }^{b}$ Cropland is not included.

${ }^{\mathrm{c}}$ Natural wetland emission ( $0.97 \mathrm{TgNyr}^{-1}$ as estimated by DLEM) is not included.

${ }^{d}$ Including emissions from fertilizer use, crops, decomposition of crops, and biomass burning.

e Including both direct and indirect emissions from fertilizer use.

${ }^{f}$ Including fertilizer use, biomass burning and manure application.

\section{Global \\ land-atmosphere \\ exchange of methane and nitrous oxide \\ H. Tian et al.}

Title Page

Abstract

Introduction

Conclusions

References

Tables

Figures

14

Back

\section{Full Screen / Esc}

Printer-friendly Version

Interactive Discussion 


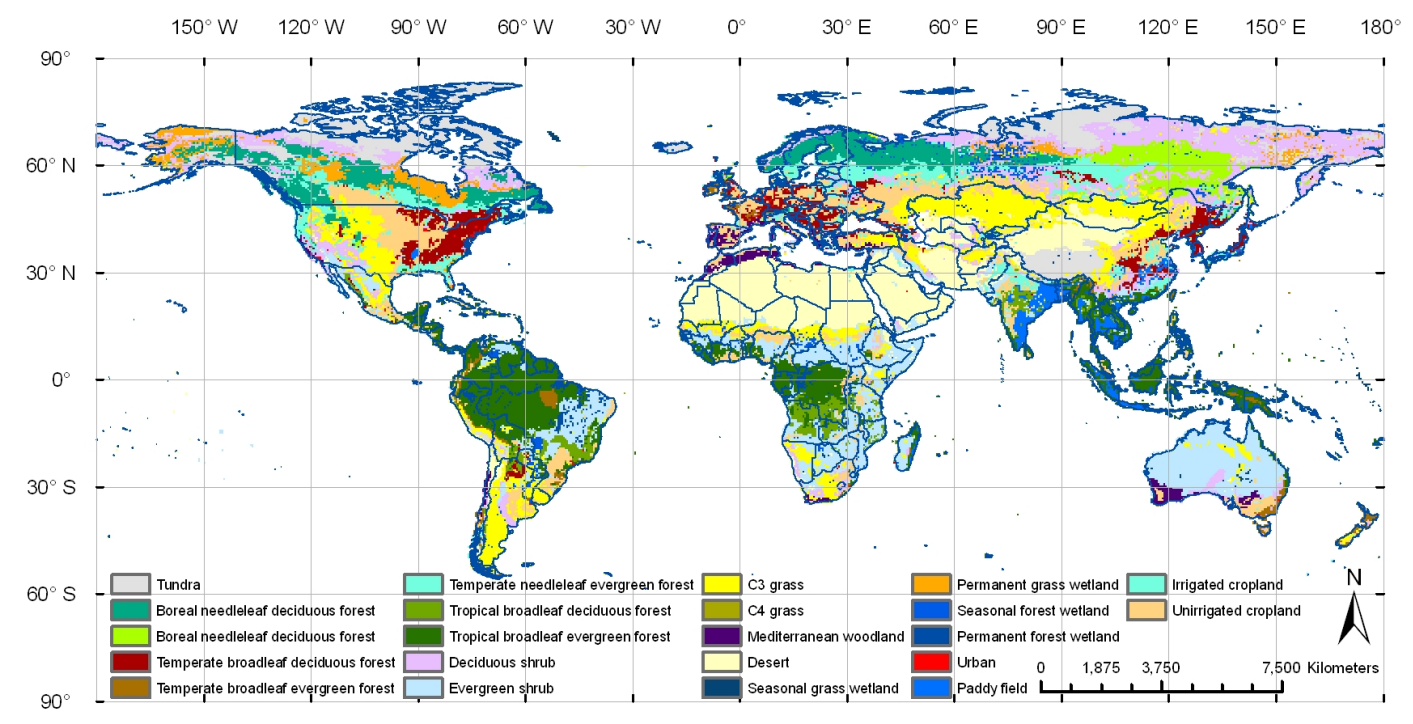

Fig. 1. Distribution of different land use and land cover types in the global terrestrial ecosystems in 2000 .

\section{BGD}

10, 19811-19865, 2013

\section{Global}

land-atmosphere

exchange of methane and nitrous oxide

H. Tian et al.

\section{Title Page}

\section{Abstract}

Introduction

Conclusions

References

Tables

Figures

14

4

Back

Close

Full Screen / Esc

Printer-friendly Version

Interactive Discussion 


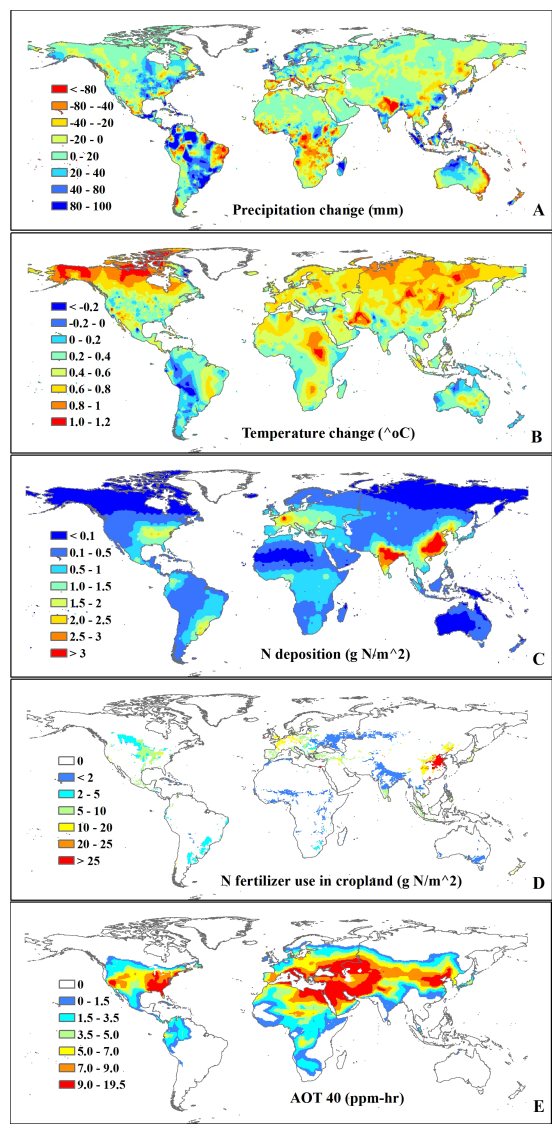

BGD

10, 19811-19865, 2013

\section{Global \\ land-atmosphere}

exchange of methane and nitrous oxide

H. Tian et al.

Title Page

Abstract

Introduction

Conclusions

References

Tables

Figures

14

$\rightarrow 1$

4

Back

Close

Full Screen / Esc

Fig. 2. Spatial distribution of environmental factors in the terrestrial ecosystems. (A) Precipitation anomaly (1981-2010mean - 1961-1990mean); (B) air temperature anomaly; (C) nitrogen deposition rate in 2010; (D) cropland distribution and nitrogen fertilizer amount in 2005; (E) Cumulative tropospheric ozone concentration above 40 ppb - hr (AOT40: ppm - hr) in July 2005.

Printer-friendly Version

Interactive Discussion 


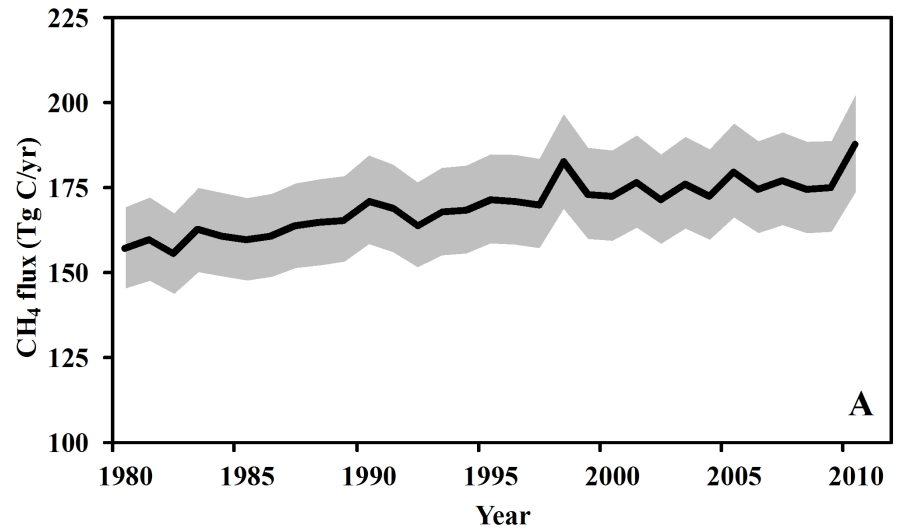

\section{BGD}

10, 19811-19865, 2013

\section{Global \\ land-atmosphere \\ exchange of methane and nitrous oxide \\ H. Tian et al.}

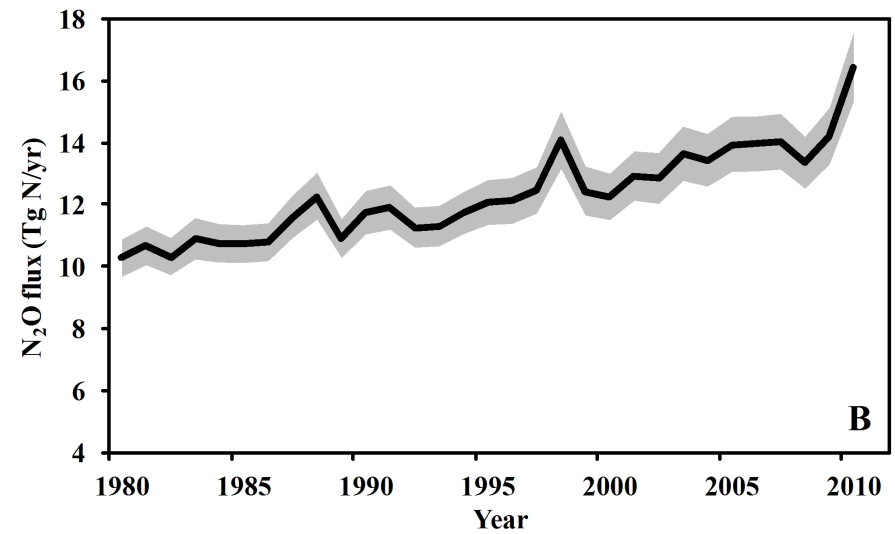

Title Page

Abstract

Conclusions

Tables

14

4

Back

\section{Full Screen / Esc}

Printer-friendly Version

Interactive Discussion 

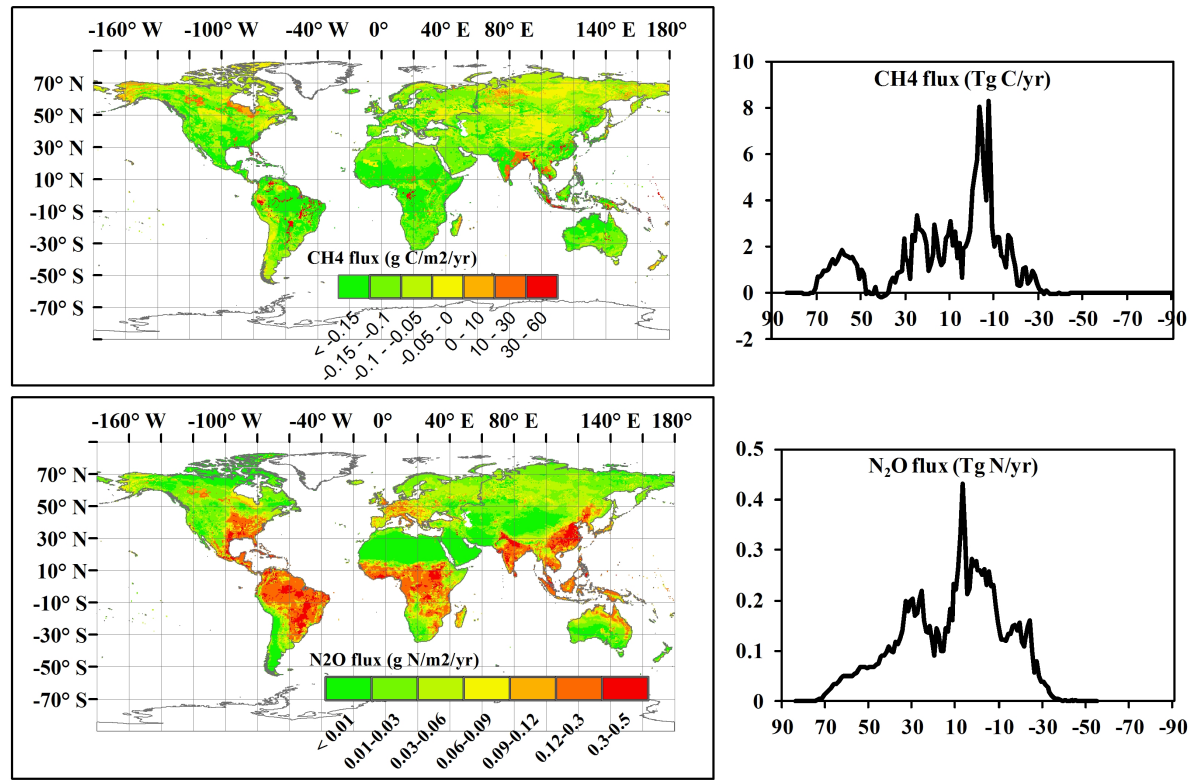

Fig. 4. DLEM-simulated mean global distributions of $\mathrm{CH}_{4}$ (top, $\mathrm{gCm}^{-2} \mathrm{yr}^{-1}$ ) and $\mathrm{N}_{2} \mathrm{O}$ (bottom, $\mathrm{m}^{-2} \mathrm{yr}^{-1}$ ) fluxes during 1981-2010. Note: The latitudinal (per degree latitude) distribution ( $\mathrm{TgCyr}^{-1}$ and $\mathrm{TgNyr}^{-1}$ for $\mathrm{CH}_{4}$ and $\mathrm{N}_{2} \mathrm{O}$, respectively) patterns are shown at the right.

\section{BGD}

10, 19811-19865, 2013

\section{Global \\ land-atmosphere \\ exchange of methane and nitrous oxide \\ H. Tian et al.}

\section{Title Page}

\section{Abstract}

Introduction

Conclusions

References

Tables

Figures

14

$\rightarrow 1$

4

Back

Close

\section{Full Screen / Esc}

Printer-friendly Version

Interactive Discussion 

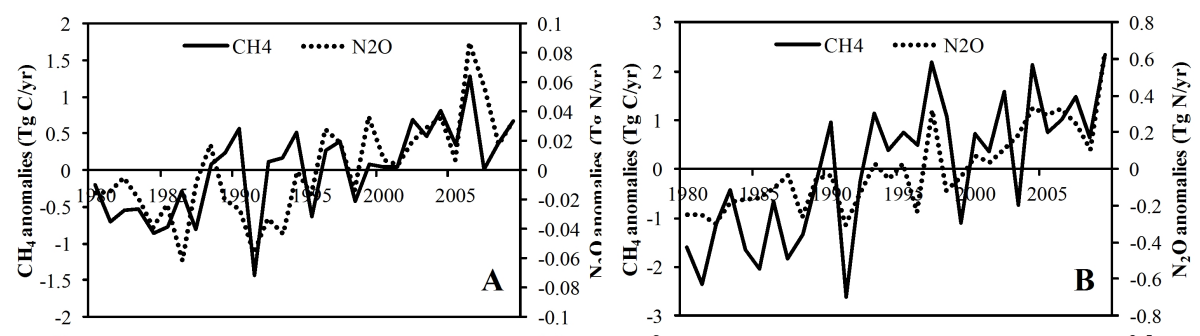

BGD

10, 19811-19865, 2013
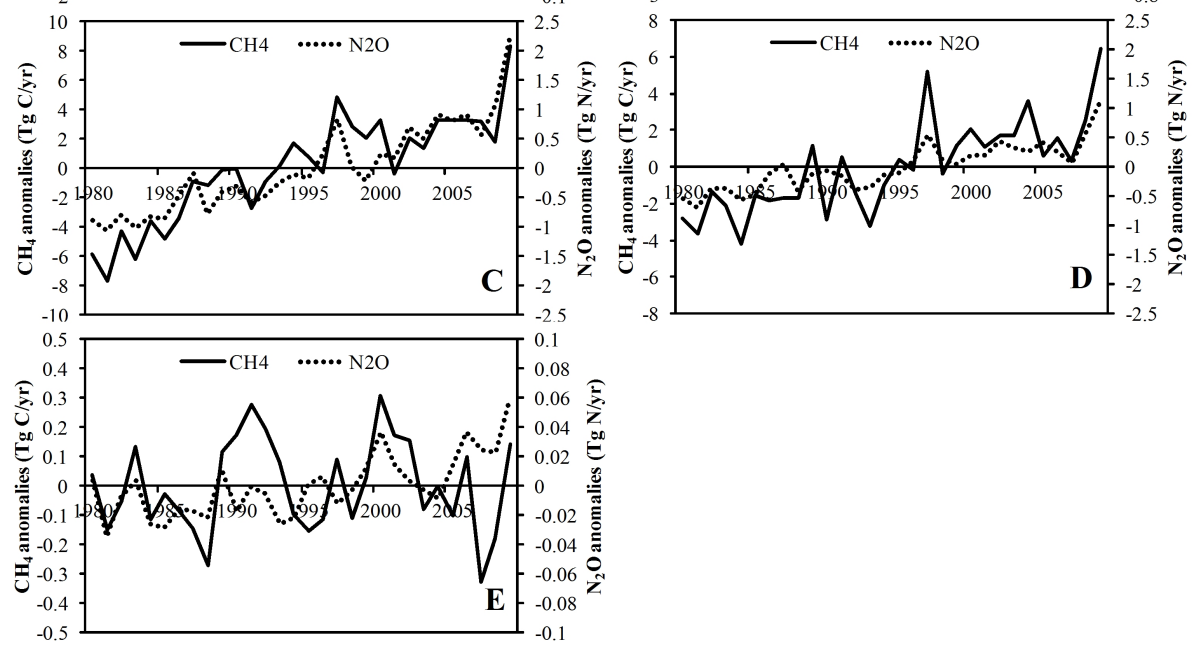

\section{Global}

land-atmosphere

exchange of methane and nitrous oxide

H. Tian et al.

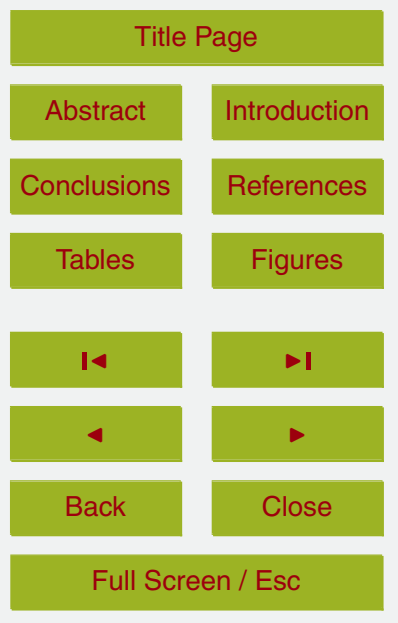

Fig. 5. Interannual variations of $\mathrm{CH}_{4}\left(\mathrm{TgCyr}^{-1}\right)$ and $\mathrm{N}_{2} \mathrm{O}\left(\mathrm{TgNyr}^{-1}\right)$ anomalies (relative to the mean value for the period 1981-2010) along a latitudinal gradient during 1981-2010. (A) The northern polar zone $\left(60-90^{\circ} \mathrm{N}\right)$; (B) the northern temperate zone $\left(30-60^{\circ} \mathrm{N}\right) ;(\mathrm{C})$ the northern tropical zone $\left(0-30^{\circ} \mathrm{N}\right)$; (D) the southern tropical zone $\left(0-30^{\circ} \mathrm{S}\right) ;(\mathrm{E})$ the southern temperate zone $\left(30-60^{\circ} \mathrm{S}\right)$.

Printer-friendly Version

Interactive Discussion 


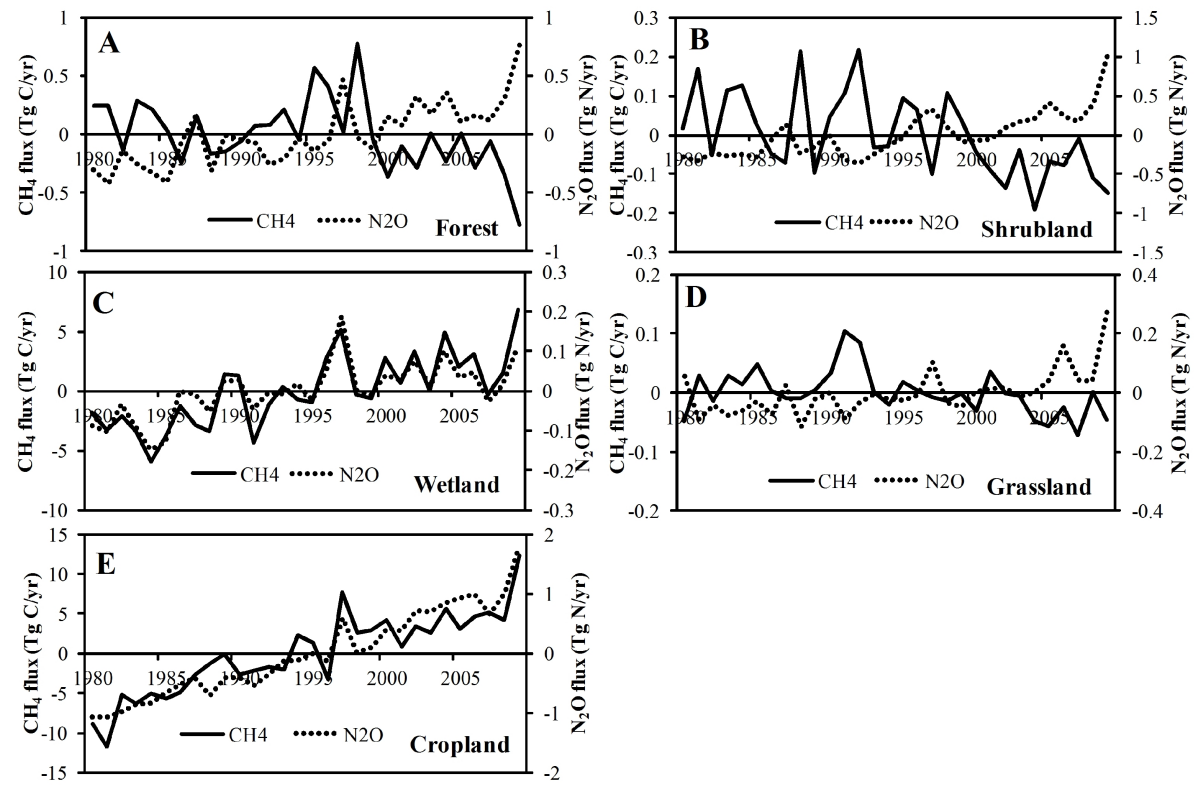

Fig. 6. Interannual variations of $\mathrm{CH}_{4}\left(\mathrm{TgCyr}^{-1}\right)$ and $\mathrm{N}_{2} \mathrm{O}\left(\mathrm{TgNyr}^{-1}\right)$ anomalies (relative to the mean value for the period 1981-2010) for different biome types during 1981-2010. (A) Forest; (B) wetland; (C) shrubland; (D) grassland; (E) cropland.
BGD

10, 19811-19865, 2013

\section{Global \\ land-atmosphere \\ exchange of methane and nitrous oxide \\ H. Tian et al.}

\section{Title Page}

Abstract

Introduction

Conclusions

References

Tables

Figures

14

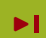

4

Back

Close

Full Screen / Esc

Printer-friendly Version

Interactive Discussion 

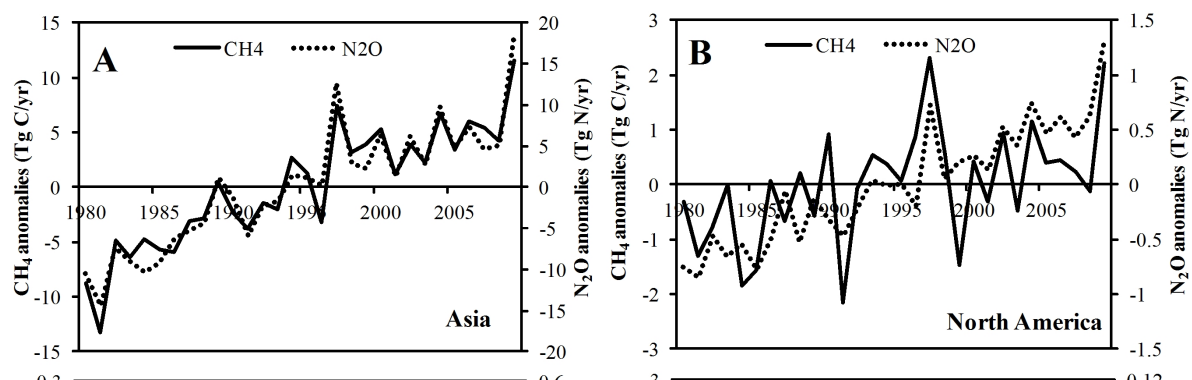

BGD
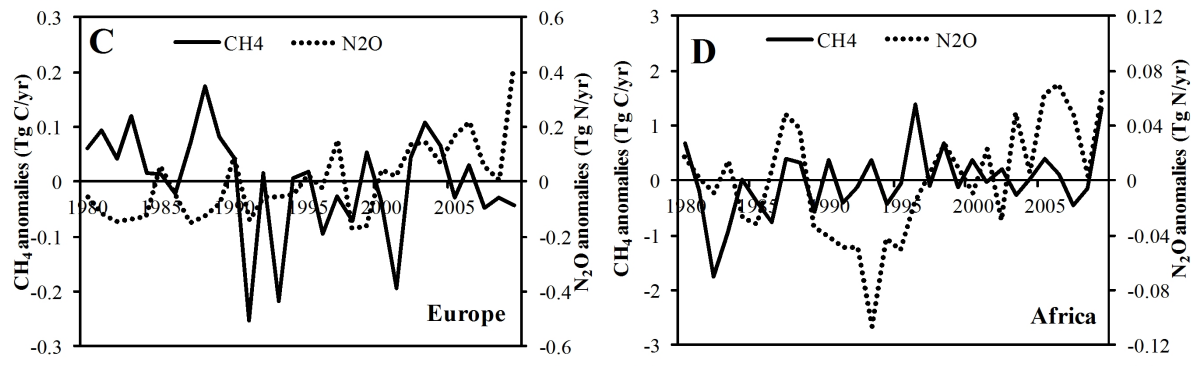

10, 19811-19865, 2013
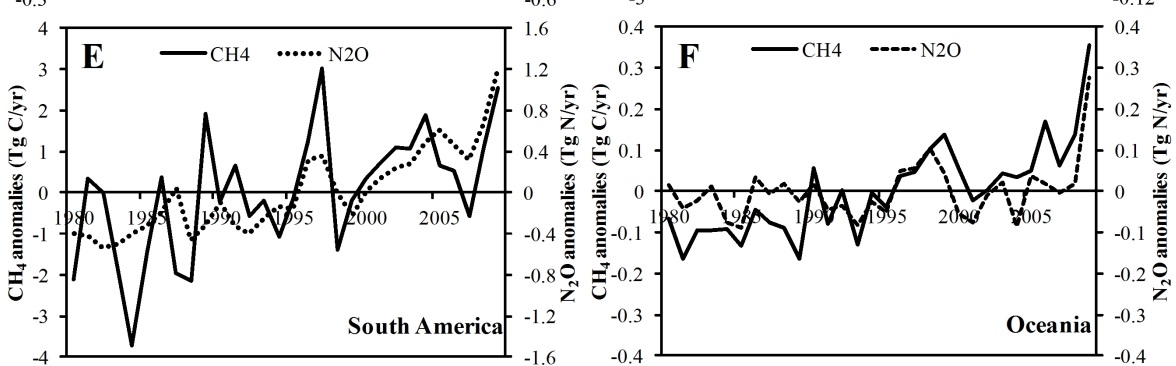

Fig. 7. Interannual variations in $\mathrm{CH}_{4}\left(\mathrm{TgCyr}^{-1}\right)$ and $\mathrm{N}_{2} \mathrm{O}\left(\mathrm{TgNyr}^{-1}\right)$ anomalies (relative to the mean value for the period 1981-2010) for different continents during 1981-2010.

\section{Global \\ land-atmosphere \\ exchange of methane and nitrous oxide \\ H. Tian et al.}

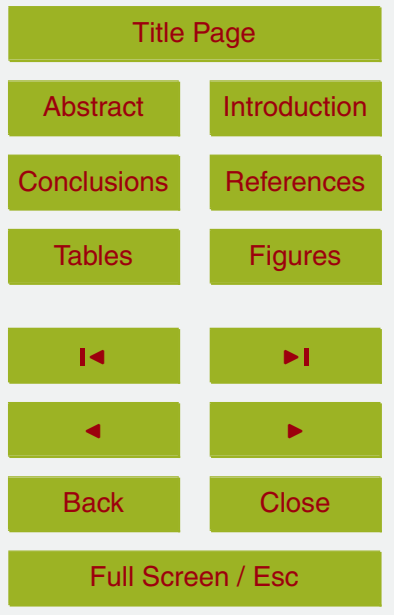

Printer-friendly Version

Interactive Discussion 